\title{
DETRITAL-ZIRCON POPULATIONS AND PROVENANCE OF MESOPROTEROZOIC STRATA OF EAST-CENTRAL IDAHO, U.S.A.: CORRELATION WITH BELT SUPERGROUP OF SOUTHWEST MONTANA
}

\author{
PAUL K. LINK \\ Department of Geosciences, Idaho State University, Pocatello, Idaho 83209, U.S.A. \\ e-mail: linkpaul@isu.edu \\ C. MARK FANNING \\ Research School of Earth Sciences, Australian National University, Canberra, ACT 0200 Australia \\ KAREN I. LUND, AND JOHN N. ALEINIKOFF \\ U.S. Geological Survey, Mail Stop 973, Denver Federal Center, Denver, Colorado 80225, U.S.A.
}

\begin{abstract}
Mesoproterozoic strata from east-central Idaho and the Belt Supergroup of southwest Montana (eight new samples) contain several age groupings of detrital zircon grains: from old to young: a) Laurentian grains older than $1.85 \mathrm{Ga}$, b) a flood of 1655 to $1790 \mathrm{Ma}$ Paleoproterozoic grains; b) non-North American zircon populations (ca. 1510 to $1625 \mathrm{Ma}$ ) with no known source on Laurentia, and c) synBelt grains, with groupings at $1480 \mathrm{Ma}$ (syn-lower Prichard) and $1450 \mathrm{Ma}$ (upper Piegan Group). The $1450 \mathrm{Ma}=$ grain age population overlaps a $1454 \pm 9$ Ma fallout tuff in Glacier National Park.

Strata of the Yellowjacket, Hoodoo, Apple Creek, and western Gunsight formations of Idaho all contain the 1450 Ma population, sparse non-North American grains, and dominant Paleoproterozoic populations at 1670 to $1790 \mathrm{Ma}$. This detrital-zircon signature is comparable to that of the Wallace Formation of the Belt Supergroup. The Swauger Quartzite in Idaho and the eastern Gunsight Formation at the ca. $900 \mathrm{Ma}$ Beaverhead impact site in southwest Montana contain 1710 and 1780 Ma zircon populations identical to those of the Missoula Group of the Belt Supergroup.

The E member of the lower Belt Prichard Formation from Plains, Montana, contains a population of syndepositional zircons at $1479 \pm$ 19 Ma. Like the Revett Formation of the Ravalli Group, the E member contains Mesoproterozoic non-North American detrital-zircon populations as well as Paleoproterozoic grains at 1750 to $1790 \mathrm{Ma}$.

The thick east-central Idaho Mesoproterozoic section was deposited after $1450 \mathrm{Ma}$, with deposition of the $10 \mathrm{~km}$ thickness from the lower Yellowjacket Formation through the Gunsight Formation spanning only 10 to 20 My. Given this very high rate of deposition, previous correlations of the Apple Creek Formation with the Piegan Group are permissible if problematic. However, previous correlations of the eastern Gunsight and Swauger formations with the Missoula Group are supported. Their detrital-zircon grain populations are identical.
\end{abstract}

\section{INTRODUCTION}

The purpose of this study is to compare new detrital-zircon age populations from Mesoproterozoic rocks of east-central Idaho with new and previously determined populations from the classic Belt Supergroup in Montana and northern Idaho. We present age data from detrital-zircon samples from the Yellowjacket Formation, Hoodoo Quartzite, Apple Creek, and western Gunsight formations of the Lemhi Group, and the Swauger Formation of east-central Idaho. We include one sample of shatter-cone-bearing strata, mapped as eastern Gunsight Formation by Ruppel (1994), from the Beaverhead impact site in southwest Montana (Figs. 1, 2). From the main Belt basin, we report new data from the Prichard Formation, member $E$, from near Plains, Montana.

Geochronology of volcanic zircons in tuffs and detrital zircons in sandstones constrains temporal correlation and tectonic models for Proterozoic basins (Ross et al., 1991; Ross et al., 1992; Ross and Villeneuve, 2003), in particular the Belt basin, within the pre-Rodinia, Siberia-Laurentia-Australia troika of Sears and Price (2003). Similarly to recent work in the Mesoproterozoic McArthur Basin of northern Australia (Jackson et al., 2000; Jackson and Southgate, 2000), zircon geochronology of the Belt Supergroup (Evans et al., 2000) has provided a chronostratigraphic and tectonic framework not available with other types of data.

\section{REGIONAL GEOLOGIC SETTING}

In ascending stratigraphic order (Fig. 2, Column A-B), the Belt Supergroup consists of (1) the lower Belt Prichard Formation (a west-derived deep-water distal clastic wedge), (2) the Ravalli Group (a west-derived fluvial system), (3) the cyclic carbonatesiliciclastic Piegan Group (containing the Helena and overlying Wallace formations and representing a complex transgressive-toregressive cycle in the Belt basin (Winston, this volume), and (4) theMissoula Group (a south-derived fluvial succession)(Harrison et al., 1974; Link et al., 1993). The Belt Supergroup was deposited in a rapidly subsiding, fault-bounded basin that overlies reworked Archean crust within the Paleoproterozoic Great Falls tectonic zone and, to the north, the Archean Medicine Hat block (O'Neill and Lopez, 1985; Foster and Fanning, 1997) (Fig. 1). Most of the supply of fine-grained siliciclastic sediment to the Belt basin came from the south and southwest (Frost and Winston, 1987; Winston and Link, 1993).

In east-central Idaho, fine-grained unfossiliferous Mesoproterozoic strata of the Yellowjacket Formation and Hoodoo Quartzite, plus Apple Creek and western Gunsight formations of the Lemhi Group, and overlying Swauger Formation, amount to a $10 \mathrm{~km}$ thickness of sedimentary rock in Cretaceous thrust sheets of the Salmon River, Lemhi, and Beaverhead Mountains (Evans and Green, 2003) (Figs. 1 and 2). The stratigraphic affinities and structural relations of these rocks have been problematic since

Proterozoic Geology of Western North America and Siberia SEPM Special Publication No. 86, Copyright $@ 2007$

SEPM (Society for Sedimentary Geology), ISBN 978-1-56576-126-1, p. 101-128. 


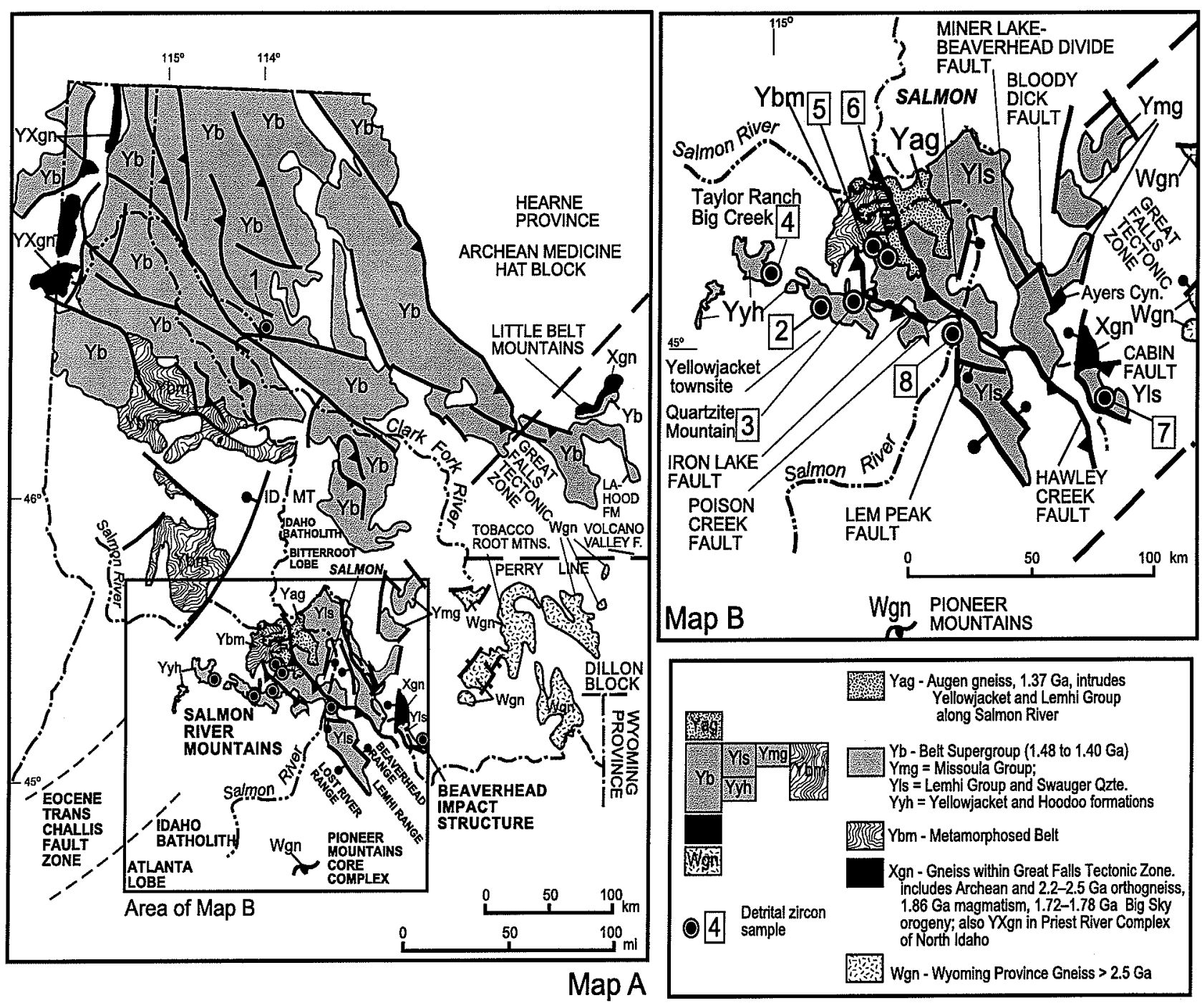

Fig. 1.-A) Generalized geologic map of Mesoproterozoic rocks of Montana and Idaho. Sample \# 1 is located. B) More detailed map of Mesoproterozoic rocks of east-central Idaho, showing sample locations 2-8. After Reed (1993), Lund (2004), Tysdal et al. (2005), and R. Lewis, Idaho Geological Survey (Digital Atlas of Idaho, 2002 (imnh.isu.edu/digitalatlas) and unpublished mapping).

early work by Umpleby (1913). Ross (1934) noted (p. 15), that "there is little if any doubt that these rocks belong to the Belt Series". However, facies change and structural complexity have precluded confident correlation. Our new data demonstrate that these strata contain the same detrital-zircon populations as the Belt Supergroup, and that the stratigraphic variation in these populations is comparable between successions.

Ruppel (1975) first noted the similarities between carbonate-siliciclastic cycles in the Apple (reek Formation at Yellow Lake in the central Lemhi Range (Fig. 1; Fig. 2, Column E) and the Helena Formation of the Belt Supergroup. In general, sedimentary structures and bedding geometry are identical between the Lemhi Group and the Belt Supergroup. Winston et al. (1999) made lithostratigraphic correlations, interpreted the Hoodoo Quartzite as a subaerial alluvial apron, and interpreted the stratigraphically overlying Apple Creek Formation to represent a continental system of sand flats, playas, and a large, westward-deepening lake. These interpretations are consistent with lacustrine and fluvial depositional models for an intracratonal Belt Supergroup (cf. Winston and Link, 1993; Winston, this volume).

Recent work by U.S. Geological Survey personnel (Tysdal, 2003; Evans and Green, 2003; Lund, 2004; Tysdal et al., 2005) does not incorporate the east-central Idaho strata in the Belt Supergroup, nor does it propose stratigraphic correlations. Tysdal $(2000 \mathrm{a}, 2003)$ inferred a tidal marine depositional setting for the Hoodoo Quartzite and a turbidite depositional setting for the structurally overlying Apple Creek Formation, inferring open connection to the world ocean during deposition of both successions. 

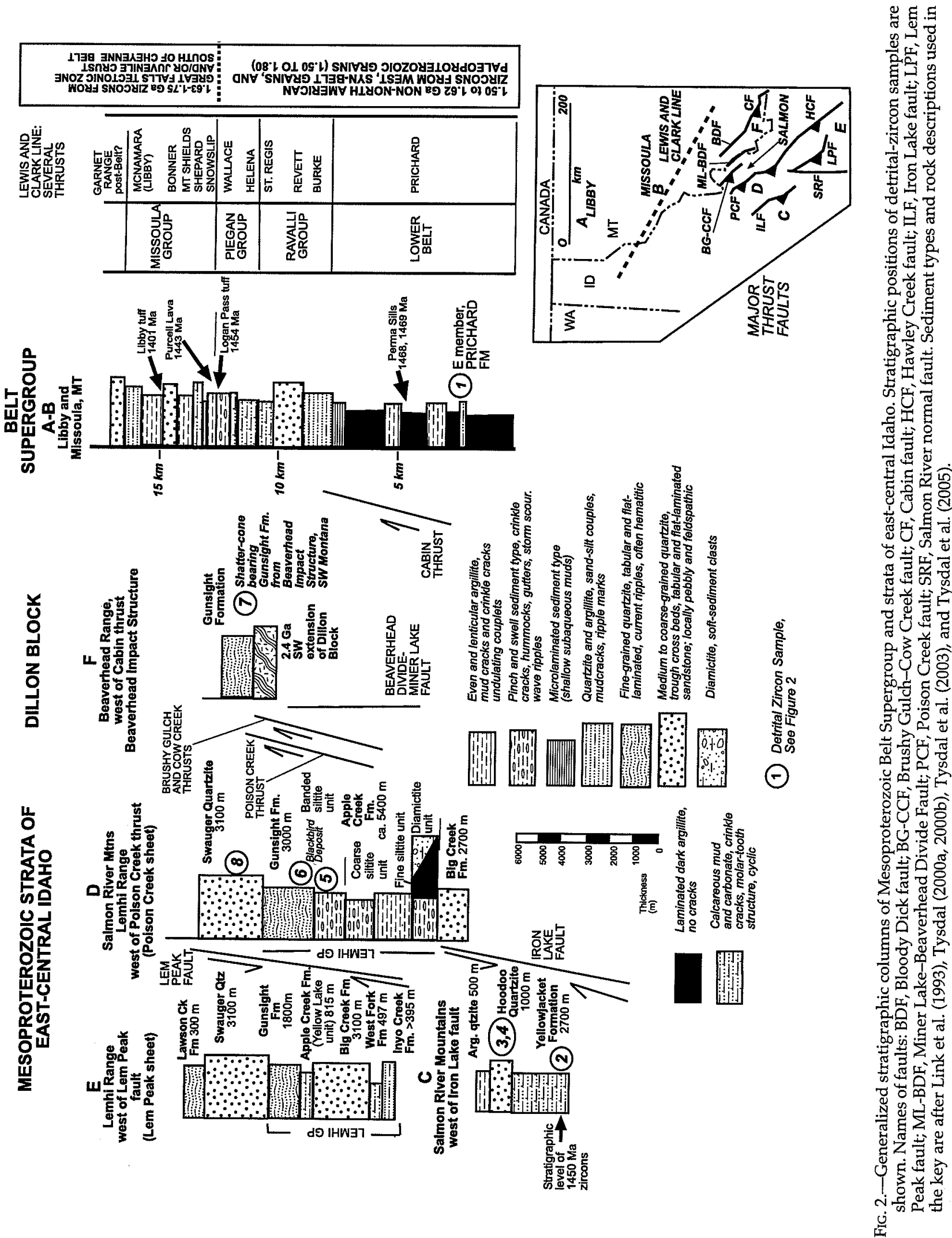


\section{Age of Belt Supergroup}

Recent geochronology of the Belt Supergroup, summarized in Figure 2, Column A-B, constrains deposition to between 1470 and $1400 \mathrm{Ma}$ (Anderson and Davis, 1995; Doughty and Chamberlain, 1996; Evans et al., 2000), a far shorter time interval than previous interpretations ( 1500 to $800 \mathrm{Ma}$; Obradovich and Peterman, 1968). Significant age constraints are: syndepositional $1470 \mathrm{Ma}$ mafic sills intruding unlithified sediments of the lower Prichard Formation (Sears et al., 1998; Schandl and Davis, 2001) and three SHRIMP U-Pb ages from upper Belt Supergroup strata in northern Montana (Evans et al., 2000). These include $1454 \pm 9$ Ma for a tuff in the upper Piegan Group of Glacier National Park*, $1443 \pm 7$ for a felsic flow at the top of the overlying Purcell lava (lower Missoula Group Snowslip Formation), and $1401 \pm 6 \mathrm{Ma}$ for a tuff in the lower Libby or uppermost Bonner Formation of the uppermost Missoula Group.

\section{Syn-Belt Faulting and Tectonic Setting}

Models for subsidence of the Belt Basin (Sears et al., 1998; Sears and Price, 2000,2003) involve an initial continental rift and subsequent tectonic load produced by basalt sills that intruded partly lithified turbidites of the Prichard Formation around 1470 Ma. The Prichard Formation, the Ravalli Group, and the bulk of the Piegan Group were deposited in only $25 \mathrm{My}$, between 1470 and about $1445 \mathrm{Ma}$. The uppermost Piegan Group and Missoula Group were deposited over a longer, perhaps $45 \mathrm{My}$ interval, with the youngest strata at about $1400 \mathrm{Ma}$ (Fig. 1).

Pointing to initially rapid but slowing subsidence rates, the presence of significant growth faults against Laurentian metamorphic basement to the south and east, and the thick westderived fine-grained Lower Belt sediment with a non-Laurentian source, Ross and Villeneuve (2003) proposed that the Belt basin formed in an extensional domain on the western part of Laurentia, inboard of a transpressional tectonic zone. Such a basin setting is analogous to the present day Black and Caspian seas.

There was intrabasinal faulting, volcanism, and basin reorganization ca. $1445 \mathrm{Ma}$, recorded in the lower Missoula Group that contains at least one unconformity, and also contains bimodal lavas (1443 $\pm 7 \mathrm{Ma}$; Evans et al., 2000) in the Snowslip Formation. This suggests basin reorganization. A change in plate motion is recorded by the Bonner disturbance, a jump in the North American paleomagnetic polar-wander path as recorded in sedimentary rocks of the upper Missoula Group (Elston and Link, 1993; Elston et al., 2002).

Lemhi Group deposition in east-central Idaho ended prior to $1370 \mathrm{Ma}$ augen gneiss that intrudes Apple Creek and Gunsight formations at Blackbird and Shoup west of Salmon (Yag in Fig. 1) (Doughty and Chamberlain, 1996; Lund and Tysdal, this volume). Coeval intrusions are found in northern Idaho (Lewis et al., this volume).

\section{REGIONAL GEOLOGY}

The Mesoproterozoic strata of east-central Idaho were deposited above crust of the northeast-striking 1860 to 1720 Ma Great Falls Tectonic Zone, which formed as the Archean Wyoming and Medicine Hat cratons collided and stabilized (Hig. 1) ( $\left({ }^{\prime}\right.$ Neill and

`Footnote: At the time it was dated, Evans et al. (2000) placed the Glacier Park tuff in the Helena Formation. Winston, (2003; this volume) places it in the upper Wallace Formation. By either interpretation, the tuffis near the ton of the Piegan Group. Houlezer, the zircons may be reworked rather than the ash being a primary frllout twff.
Lopez, 1985; O'Neill, 1988; Mogk et al., 1992; Mueller et al., 2002; Mueller et al., 2005). The term Big Sky orogeny is used for 1780 to 1720 Ma plate collision along the Great Falls zone in the Tobacco Root Mountains, during which juvenile Proterozoic mafic crust was thrust southward over the Dillon Block of the Archean Wyoming Province (Burger, 2004; Harms et al., 2004).

In southwest Montana, the southeast edge of the Belt basin is the east-trending Perry line, (Fig. 1, Map A), which was a downto-the-north synsedimentary normal fault during deposition of the lower Belt LaHood Formation (McManus, 1963; McTeague and Schmitt, 2003). South of the Perry line are Archean and Paleoproterozoic metamorphic rocks of the Dillon block, including the Great Falls Tectonic Zone. The Perry line extends westward from the syndepositional Volcano Valley Fault in the Helena embayment of the main Belt Basin (Fig. 1A) (Winston, 1986).

\section{Mesozoic and Cenozoic Deformation}

The crust of central Idaho was overthickened during the Mesozoic Cordilleran orogeny by east-dipping subduction, formation of a magmatic arc, and east-vergent thrust faulting. South of the Salmon River, the Late Cretaceous Atlanta lobe of the Idaho batholith (100 to $80 \mathrm{Ma}$ ) (Lewis et al., 1987) intruded Proterozoic and Phanerozoic strata. Cretaceous thrust faults strike northwestward into the magmatic belt (Skipp, 1987). In Tertiary time, the area was multiply extended through changing extension directions (Dover, 1981, 1983; Wust, 1986; O'Neill and Pavlis, 1988; Janecke, 1994; Janecke et al., 1998; Janecke et al., 1999; Janecke et al., 2001).

\section{MESOPROTEROZOIC STRATIGRAPHY OF EAST-CENTRAL IDAHO AND THE BEAVERHEAD MOUNTAINS}

\section{Distribution of Stratigraphic Units}

The distribution of formations and the structural geometry from the Salmon River Mountains east to the Montana border is significantly revised (Tysdal 2000a, 2000b; Tysdal et al., 2003) as shown on the geologic maps of the Salmon (Evans and Green, 2003) and Payette (Lund, 2004) National Forests and simplified in Figure 1. The Yellowjacket Formation and overlying Hoodoo Formation and argillaceous quartzite crop out in a regional thrust sheet west of the Iron Lake Fault (Fig. 1B, Stratigraphic column, Fig. 3). Units of the Lemhi Group plus Swauger Formation crop out on several thrust sheets east of the Iron Lake Fault (Tysdal, 2002). These thrusts are parallel to the Hawley Creek Thrust of the Beaverhead Mountains to the southeast (Lucchitta, 1966; Skipp, 1987, 1988; Rodgers and Janecke, 1992; Janecke et al., 2000). In the west, Yellowjacket, Hoodoo, and Lemhi Group units are recognized as pendants across the Idaho Batholith (Lund, 2004).

In the east, in southwest Montana, the steeply dipping Miner Lake-Beaverhead Divide shear zone (Ruppel and Lopez, 1984) separates strongly tectonized and mylonitic Lemhi Group ( $O^{\prime}$ Neill et al., 2005) on the west from less-deformed pebbly sandstone assigned to the Missoula Group, undivided (Evans and Green, 2003). These coarse-grained rocks lie unconformably on $2.4 \mathrm{Ga}$ basement at Ayers (anyon, east of the Beaverhead Divide-Miner Lake Fault (M'Gonigle, 1993) (Figs. 1, 2). Tysdal et al. (2005) tentatively assigned these rocks to the Gunsight Formation.

Farther east is the Bloody Dick fault zone (Fig. 1A), which strikes southeast into the Cabin Thrust (Fig. 2). East of that fault are Missoula Group strata of the Big Hole Divide area (Ruppel et al., 1993; Tysdal et al., 2005). 


\section{Distinction of Yellowjacket Formation from Apple Creek Formation}

In the Salmon River and Beaverhead Mountains, the stratigraphy of the Yellowjacket Formation and the Lemhi Group (Fig. 2) has recently been clarified with major revision by restricting the name Yellowjacket Formation to strata stratigraphically below the Hoodoo Quartzite (Fig. 3). Mineralized strata in the Blackbird mining district and rocks formerly mapped as Yellowjacket Formation in the northeastern Salmon River and Beaverhead Mountains (Ruppel et al., 1993) are included in the Apple Creek Formation (Tysdal, 2000a, 2000b, 2003) (Figs $2,3)$.

These definitions corroborate and extend stratigraphic conclusions previously made independently (Winston et al., 1999). Stratigraphic and structural models from pre-1990 that invoke the "Salmon River" or "Lemhi" arches and the "Medicine Lodge thrust fault" (Harrison et al., 1974; Armstrong, 1975; Ruppel, 1975, 1986; Ruppel and Lopez, 1984) have been rejected on structural and stratigraphicgrounds (Evans and Zartman, 1990; Evans, 1998; Winston et al., 1999; Tysdal, 2002; Link et al., 2003; Lund, 2004).

\section{Lemhi Group Stratigraphy \\ Across East-Central Idaho}

\section{Lemhi Range Type Area.-}

The Lemhi Group was defined in the Lemhi Range (Fig. 1), where it contains the fine-grained, mainly siliciclastic Inyo Creek, West Fork, Big Creek, Apple Creek, and Gunsight formations (Fig. 2, Column E) (Ruppel, 1975). These are overlain by the coarser-grained Swauger Formation. Locally the Lawson Creek Formation lies at the top of the succession (Hobbs, 1980).

The principal reference section for the Apple Creek Formation is west of Yellow Lake (Fig. 2, Column E; Golden Trout Lake of Ruppel, 1975). The Apple Creek Formation here consists of three units, a lower green and purple mudrock, with sparse mudcracks $(360 \mathrm{~m})$, a medial green, fine sandy interval with lenticular and even couplets of silt to clay $(>140 \mathrm{~m}$ ), and an upper carbonate-bearing cyclic unit over $360 \mathrm{~m}$ thick (Winston et al., 1999). This upper mixed siliciclastic and carbonate unit contains about 55 meter-scale cycles (parasequences) in a thickness of about $300 \mathrm{~m}$. The lower halfcycles contain green uncracked lenticular couples, and the upper half-cycles contain purple mudcracked even couplets.

The strongest lithostratigraphic tie between the Lemhi Group and the Belt Supergroup is between

$\rightarrow$

FIG. 3.-Generalized Mesoproterozoic stratigraphy, Salmon River Mountains, central Idaho. Stratigraphic column across the Iron Lake Fault shows locations of several detrital zircon samples. Modified from Link et al. (2003) with descriptions of Evans and Green (2003).

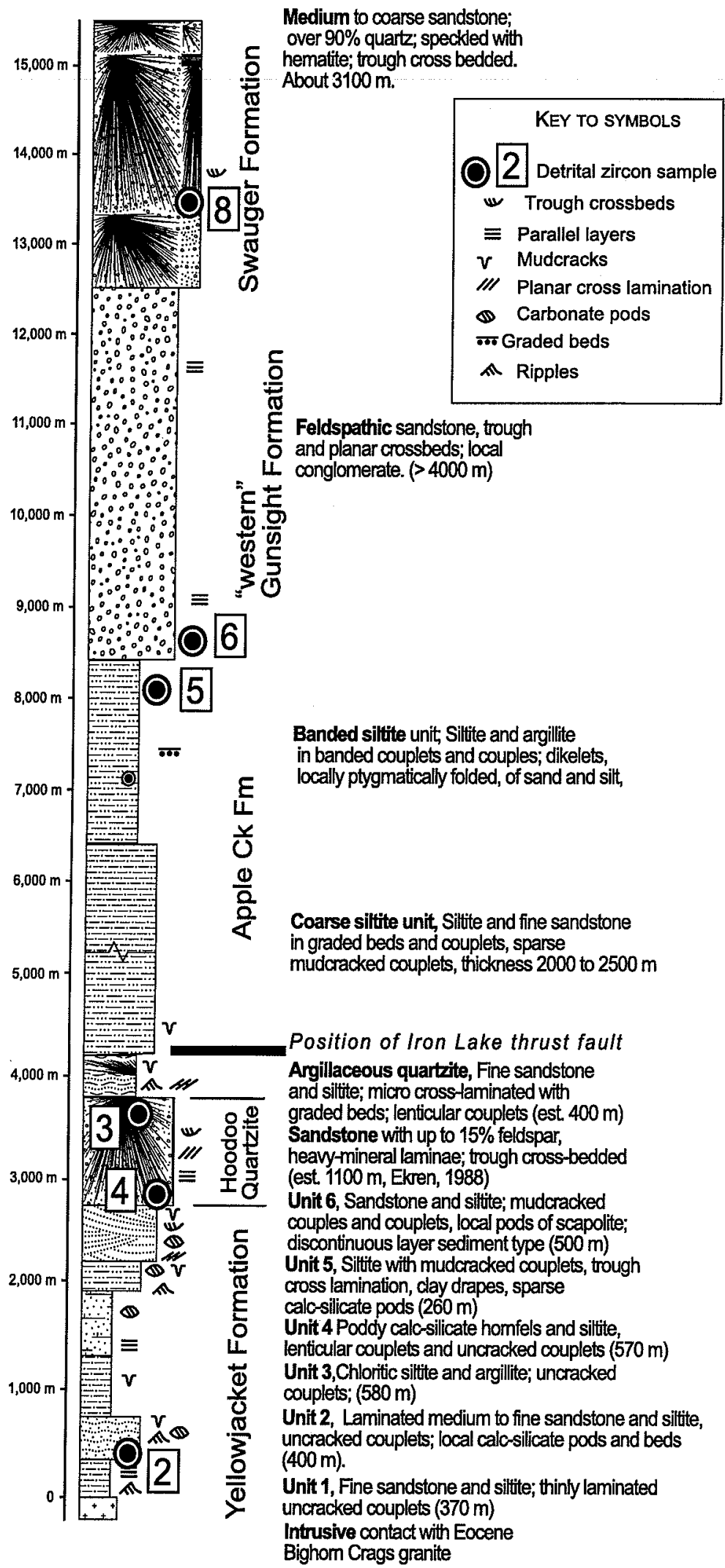


this upper carbonate unit of the Apple Creek Formation type section at Yellow Lake (Column E of Fig. 2) and cyclic strata in the Piegan Group. Tysdal $(2000 a, 2003)$ found the Yellow Lake facies to be only locally developed in the Apple Creek Formation in the northern Lemhi Range, and thus designated the type section as "not typical". There is ongoing controversy over the identification and extent of the Apple Creek and overlying Gunsight formations in different thrust sheets in the Beaverhead Mountains (J.M. O'Neill, written communication, April 2006).

\section{Apple Creek Diamictite.-}

Strata included in the Apple Creek Formation change character significantly across thrust faults in east-central Idaho. North of the type area, in the northern Lemhi Range on the Poison Creek thrust sheet, east of the Lem Peak Fault, the Apple Creek Formation thickens abruptly (Column D, Fig. 2) (Tysdal, 2000a, Tysdal et al., 2003). On the eastern, basinal side of the Lem Peak Fault the Apple Creek contains fine siltite and mass-flow diamictite, likely generated by synsedimentary mass flow across a syndepositional fault (Tietbohl, 1986).

\section{Blackbird Mining District.-}

To the north, on the Poison Creek thrust sheet in the Salmon River Mountains (Column D of Fig. 2), the Apple Creek Formation contains fine, coarse, and banded siltite units. Prominent sedimentary structures include dark-colored lenticular and undulating couplets, oscillation ripples, crinkle cracks, and hummocky cross bedding (Winston et al., 1999; Link et al., 2003). In the Blackbird district, hummocky cross-bedded "pinch and swell" quartzite and siltite forms the uppermost part of the formation.

Cobalt-copper deposits in the upper part of the banded siltite unit form a resource in the Blackbird mining district (Fig. 1, Map B). These beds are interpreted to have been deposited in an extensional basin, locally subjected to sediment-hosted, possibly syngenetic mineralization from hydrothermal vents (Hahn and Hughes, 1984; Nash and Hahn, 1989; Tysdal and Desborough, 1997; Lund and Tysdal, this volume).

In the Blackbird district, the overlying western Gunsight Formation contains purple to medium gray, tabular flat-laminated, climbing-ripple-bearing sandstone with even uncracked and mudcracked couplets, representing fluvial deposition. The Gunsight is overlain by lighter-colored and locally coarser-grained sandstones of the Swauger Formation.

The Swauger Formation generally consists of coarse- to finegrained feldspathic arenite. It is correlated with Mt. Shields Formation member 2 of the Belt Supergroup by Farooqui (1994). Winston et al. (1999, p. 17) interpreted the Swauger to be the southern part of an immense north-thinning alluvial sand wedge that extended northward to beyond the Canadian border and contains both the Mount Shields and Bonner formations.

\section{Yellowjacket District, West of Iron Lake Fault.--}

Westward, on the Iron Lake sheet (Column C, Fig. 2), the Yellowjacket Formation, the overlying Hoodoo Quartzite and unnamed argillaceous quartzite (Yaq) are recognized in the Yellowjacket mining district (Ekren, 1988) and west across the Middle Fork of the Salmon River in the Payette National Forest (Lund, 2004). A traverse of the thickest $(2700 \mathrm{~m}$ ) exposed section of Yellowjacket Formation at the reference locality (Ross, 1934), south of Yellowjacket Creek (Fig. 1, Map B), can be divided into six informal units (Fig. 3). The upper part of the section locally contains scapolite, which is interpreted to represent metamorphosed carbonate (possibly dolomite) and evaporite minerals (Tysdal and Desborough, 1997; Tysdal, 2000b). Structural repetition within the section cannot be excluded.

The Hoodoo Quartzite is a cliff-forming quartz arenite marker unit above the Yellowjacket Formation. It is recognized from the Yellowjacket mining district west across the Middle Fork Salmon River to Taylor Ranch on Big Creek in the Payette National Forest (Fig. 1) (Lund, 2004).

Winston et al. (1999) describe the rocks of the Yellowjacket area as part of a general east-dipping homoclinal section below the Apple Creek Formation, following map interpretations of Ekren (1988). Tysdal (2000b) emphasizes the Iron Lake fault as bounding a regional thrust sheet and does not relate the Yellowjacket, Hoodoo, and argillaceous quartzite units to the Apple Creek Formation east of the fault.

\section{Lemhi Group in the Beaverhead Mountains.-}

In the Beaverhead Mountains, east of the Poison Creek thrust fault, and west of the Miner Lake-Beaverhead Divide fault, the Apple Creek and the overlying Gunsight formations are mapped (Evans and Green, 2003). East of the Miner Lake shear zone is a very thick $(>5000 \mathrm{~m})$ conglomeratic trough- and planar crossbedded sandstone mapped as undifferentiated Missoula Group by Evans and Green (2003). These strata coarsen southward, toward a basal unconformity at Ayers Canyon (Fig. 1, Map B) above Paleoproterozoic rocks of the Great Falls Tectonic Zone (M'Gonigle, 1993, 1994).

At the Beaverhead Impact locality in the southeastern Beaverhead Mountains (Column F in Fig. 2) fine-grained ripple crosslaminated Gunsight Formation contains shattercones from a meteorite impact thatoccurrednear 900Ma(Ruppel, 1994; Kellogg et al., 2003). Skipp and Link (1992) interpreted pebbly quartzite in this area to be Cambrian and Neoproterozoic Wilbert Formation, though the strata at the shattercone locality must be Mesoproterozoic because the unit bears 900 Ma deformation features.

\section{STUDIES OF DETRITAL ZIRCONS}

We present eight new detrital-zircon data sets. Table 1 contains the location of each sample. Table 2 contains a summary of the major grain age populations. Data tables are presented in Table 3, located after the references.

Detrital-zircon studies of Belt-Purcell Supergroup strata in Montana and British Columbia were initiated by Ross et al. (1992), with new data synthesized by Ross and Villeneuve (2003). Ross and colleagues recognized several detrital-zircon populations in the Belt-Purcell Supergroup. These are the same populations that we recognize in our samples (Table 2). Cathodoluminescence images of grains from these various populations are shown in Figure 4. The populations include (A) Archean and Paleoproterozoic magmatic and metamorphic grains older than $1800 \mathrm{Ma}$, having multiple possible source areas within Laurentia to the east, (B) voluminous mainly magmatic Paleoproterozoic grains, 1650 to $1820 \mathrm{Ma}$, that may have come from within Laurentia and/or otherPaleoproterozoicorogenicbelts, (C) magmatic grains from 1510 to $1620 \mathrm{Ma}$ that are "non-North American" and may ultimately have come from Australia, and (D) magmatic grains from 1400 to $1470 \mathrm{Ma}$ that are syn-Belt Supergroup. These synBelt grains may have been derived from midcontinent A-type magmatism within Laurentia (Anderson 1989; Frost and Frost, 1997; Frost et al., 1998; Anderson and Morrison, 2005) and/or from volcanism in western parts of the Belt basin (Ross and Villeneuve, 2003). 
TABLE 1.-Sample locations for detrital zircon samples. GPS precision is $\pm 10 \mathrm{~m}$, in NAD 27 UTM coordinates.

\begin{tabular}{|c|c|l|c|c|}
\hline $\begin{array}{c}\text { \# on Figs. 1, } \\
\mathbf{2 , 5}\end{array}$ & $\begin{array}{c}\text { Sample } \\
\text { Number }\end{array}$ & Sample Location & Easting & Northing \\
\hline $\mathbf{1}$ & BB-31 & E member, Prichard Fm., Plains, MT & 1IT 666010 & 5242488 \\
\hline $\mathbf{2}$ & 13PL01 & Lowest sand in Yellowjacket Fm. type area, ID & $11 \mathrm{~T} 694548$ & 4991514 \\
\hline $\mathbf{3}$ & 95ITz234 & Hoodoo Quartzite, Quartzite Mountain, ID & $11 \mathrm{~T} 700942$ & 4992942 \\
\hline $\mathbf{4}$ & 02RL888 & Hoodoo Quartzite, Taylor Ranch, Big Creek, ID & $11 \mathrm{~T} 669732$ & 4996421 \\
\hline $\mathbf{5}$ & SS95-19a & $\begin{array}{l}\text { Banded siltite unit, Apple Creek Fm., Drillcore, Blackbird } \\
\text { District, ID }\end{array}$ & 11T 707450 & 5000600 \\
\hline $\mathbf{6}$ & 39PL02 & $\begin{array}{l}\text { Lower Gunsight Fm., Haynes Stellite Mine, Blackbird } \\
\text { District, ID }\end{array}$ & 11T 694548 & 4998522 \\
\hline $\mathbf{7}$ & 23PL92 & Eastern Gunsight Fm., Beaverhead Impact site, MT & 12T 345171 & 4942018 \\
\hline $\mathbf{8}$ & 95ITz101 & Swauger Quartzite, Salmon River north of Challis, ID & 12T 264654 & 4968551 \\
\hline
\end{tabular}

The flood of Paleoproterozoic 1655 to 1820 Ma zircon grains defines the zircon population of the upper and middle parts of the Belt Supergroup. These grains have multiple possible source areas. The most proximal is the Great Falls Tectonic Zone within the Big Sky orogen, southeast of the Belt Basin (Fig. 1, Map A) (Harms et al., 2004). Distal possible source areas include the complex of orogenic belts on the southern margin of the Wyoming Province, including the rocks deformed in the $1780 \mathrm{Ma}$ Medicine Bow orogeny of Chamberlain (1988), the $1650-1800 \mathrm{Ma}$ juvenile arcs of the Yavapai and Mazatzal provinces of northern Arizona (Karlstrom and Bowring, 1988, 1993), and evolved arcs of the > 1800 Ma Mojave Province (Barth et al., 2000; Duebendorfer et al., 2001). In the reconstruction of Sears and Price (2003), these orogenic belts form the eastern part of the Ulkan-Colorado magmatic belt, which crosses from Laurentia into northern Siberia (see Fig. 14 of this paper).

A non-Laurentian source for some of the Paleoproterozoic zircon grains is also possible, inasmuch as 1650 to $1800 \mathrm{Ma}$ magmatism is also found in Siberia and northern Australia (Ross and Villeneuve, 2003).

\section{Hand-Picked Versus Random Grain Selection}

Ross and Villeneuve (2003) analyzed between 18 and 34 handpicked zircons per sample, in order to sample every population of grains based on morphology, and used both TMMS and, later SHRIMP analyses. We analyzed about 60 random grains per sample using the SHRIMP; the 60 grain sample is based on Dodson et al. (1988). Concerns have been raised about statistical reproducibility of small, non-random sample protocols (Vermeesch, 2004). In our experience (cf. Link et al., 2005) it is the more prominent age groupings (or peaks) on detrital zircon age spectra that are the key to characterizing provenance and sources. Without considerably more analyses (perhaps 117 grains as indicated by Vermeesch, 2004), one or even two grains in an isolated population can be considered to be simply background noise and not of a significant geological meaning.

\section{Methods of This Study}

Detrital-zircon samples were collected from $2-5 \mathrm{~kg}$ grab samples from medium- and fine-grained sandstones (including rocks mapped as "quartzites"). A heavy-mineral concentrate was prepared from the total rock using standard crushing, washing, heavy liquid (Sp. Gr. 2.96 and 3.3), and paramagnetic procedures The zircon-rich heavy-mineral concentrates were poured onto double-sided tape, mounted in epoxy together with chips of the reference zircons (FC1, and SL13), sectioned approximately in half, and polished. Reflected-light and transmitted-light photomicrographs were prepared for all zircons. Cathodoluminescence (CL) scanning electron microscope (SEM) images were prepared for all zircon grains and used to decipher the internal structures of the sectioned grains. Some of these grain types are shown in Figure 4.

The U-Th-Pb analyses were made using SHRIMP I or SHRIMP RG at the Research School of Earth Sciences, The Australian National University, Canberra, Australia. For each sample, zircons on the mount were analyzed sequentially and randomly until a total of at least 60 grains for each sample was reached. Each analysis consisted of four scans through the mass range, with a reference zircon analyzed for every five unknown zircon analyses (Williams, 1998, and references therein). The data have been reduced using the SQUID Excel Macro of Ludwig (2001).

$\mathrm{Pb} / \mathrm{U}$ ratios have been normalized relative to the value of 0.01859 for the FC1 reference zircon, equivalent to an age of 1099 Ma (see Paces and Miller, 1993). Uncertainties given for individual analyses (ratios and ages) are at the one-sigma level; however, the uncertainties in calculated weighted mean ${ }^{207} \mathrm{~Pb} /$ ${ }^{206} \mathrm{~Pb}$ ages are reported as $95 \%$ confidence limits. Tera and Wasserburg (1972) and Wetherill concordia plots, probabilitydensity plots with stacked histograms $\left({ }^{207} \mathrm{~Pb} /{ }^{206} \mathrm{~Pb}\right.$ ages), and weighted mean ${ }^{207} \mathrm{~Pb} /{ }^{206} \mathrm{~Pb}$ age calculations were carried out using ISOPLOT/EX (Ludwig, 2003). Using the "Mixture Modeling" algorithm of Sambridge and Compston (1994), via ISOPLOT/ EX, approximate age populations were unmixed to assist in the definition of various groupings.

Analyses that are greater than $10 \%$ discordant were not included in the histograms and probability density plots shown as Figures 4 through 12. On the Wetherill concordia plots for those figures, the discordant grains are shown as filled circles.

\section{DISCUSSION OF SPECIFIC DETRITAL-ZIRCON SAMPLES}

\section{Prichard Formation (Sample \# 1; BB31; Fig. 5)}

Sample BB-31 is a medium-grained sandstone from the $\mathrm{E}$ member of the Prichard Formation (Fig. 1A), collected from its best-described section, near Plains, Montana (Cressman, 1989). Sixty-three grains were analyzed. The probability-density plot is in Figure 5, and the data are in Table 3A. 
TABLE 2.-Summary of age populations for all samples in this paper, plus Revett and Wallace formations, and Missoula Group samples of Ross et al. (1991), Ross et al. (1992), and Ross and Villeneuve (2003).

\begin{tabular}{|c|c|c|c|c|c|c|c|c|c|c|c|}
\hline \multirow[b]{2}{*}{$\begin{array}{c}\text { Population } \\
\text { age (Ma) }\end{array}$} & \multicolumn{2}{|c|}{ Syn-Belt grains } & \multicolumn{3}{|c|}{$\begin{array}{c}\text { Non-North } \\
\text { American grains }\end{array}$} & \multicolumn{6}{|c|}{ Paleoproterozoic grains } \\
\hline & 1450 & 1480 & 1500 & 1550 & $\begin{array}{l}1610- \\
1615\end{array}$ & $\begin{array}{l}1655- \\
1670\end{array}$ & $\begin{array}{l}1680- \\
1690\end{array}$ & $\begin{array}{c}1710- \\
1725 \\
\end{array}$ & $\begin{array}{l}1740- \\
1760\end{array}$ & $\begin{array}{l}1775- \\
1790\end{array}$ & 1820 \\
\hline \multicolumn{12}{|c|}{ Prichard and Ravalli Groups } \\
\hline $\begin{array}{l}\text { Prichard Fm. } \\
\text { BB31 }\end{array}$ & & $1479 \pm 19 \mathrm{Ma}$ & & 1550 & 1615 & & & & 1750 & & \\
\hline Revett Fm. & & & 1500 & & 1610 & & & & & 1790 & \\
\hline \multicolumn{12}{|c|}{ Piegan and Lemhi Groups and Yellowjacket Formation } \\
\hline $\begin{array}{l}\text { Yellowjacket Fm } \\
\text { 13PL01 }\end{array}$ & $1454 \pm 9 \mathrm{Ma}$ & & & & & 1675 & & 1720 & & & \\
\hline \begin{tabular}{|l} 
Hoodoo Qzte, \\
95ITz234 \\
\end{tabular} & $1448 \pm 10 \mathrm{Ma}$ & & & & & 1670 & & & 1750 & 1790 & \\
\hline $\begin{array}{l}\text { Hoodoo Qzte., } \\
\text { Big Creek } \\
\text { 02RL888 }\end{array}$ & $1445 \pm 12 \mathrm{Ma}$ & & & & & & 1690 & 1725 & & 1775 & \\
\hline $\begin{array}{l}\text { Apple Creek Fm. } \\
\text { SS95-19 }\end{array}$ & $1446 \pm 35 \mathrm{Ma}$ & & & & & & 1680 & & 1740 & & 1820 \\
\hline $\begin{array}{l}\text { western Gunsight Fm. } \\
\text { 39PL02 }\end{array}$ & & & & & & & 1685 & & & 1780 & \\
\hline Wallace Fm. & & & & 1540 & & & 1680 & & 1750 & & \\
\hline \multicolumn{12}{|c|}{ Missoula Group, Swauger and Eastern Gunsight Formations } \\
\hline $\begin{array}{l}\text { eastern Gunsight Fm.- } \\
\text { Beaverhead Impact } \\
\text { 23PL92 }\end{array}$ & & & & & & 1655 & 1690 & & 1740 & & \\
\hline Swauger Fm. 95ITz101 & & & & & & & 1680 & 1720 & 1760 & & \\
\hline Missoula Gp. & & & & & & & & 1710 & & 1780 & \\
\hline
\end{tabular}

Italic entries are from Ross' work, and include TIMS analyses with smaller error than SHRIMP analyses. The listed age populations are statistically possible given ages of detrital zircons in each sample. However, they may not reflect distinct empirical populations of grains.

The majority of the detrital zircon ages are in the range ca. 1550 to ca. $1615 \mathrm{Ma}$, with another significant grouping between ca. $1750 \mathrm{Ma}$ and $\mathrm{ca} .1790 \mathrm{Ma}$. Three grains define the youngest population at $1479 \pm 19 \mathrm{Ma}$ (weighted mean ${ }^{207} \mathrm{~Pb} /{ }^{206} \mathrm{~Pb}$ ages). This constrains the maximum age for the lower Prichard Formation in one of its thickest sections. There are scattered older grains, with the oldest grain at ca. $2565 \mathrm{Ma}$.

The detrital-zircon age spectrum recorded for this sample is similar to those reported in previous studies from the Prichard Formation (Ross etal., 1992; Ross and Villeneuve, 2003). Cressman (1989) recognized that the Prichard was a vast turbidite fan system, with a fluvial point source on the southwest side of the Belt Basin. Ross et al. (1992) recognized the presence of 1510 to $1625 \mathrm{Ma}$ grains in the Prichard and also their value as a nonNorth American provenance indicator. Suggestions for possible sources of the grains include derivation from North Queensland, Australia (Blewettet al., 1998; Sears and Price, 2003) or the Gawler
Craton of South Australia (Ross et al., 1992). Whilst both of these sources may have provided the ca. $1550-1615 \mathrm{Ma}$ zircons, provenance from the Gawler Craton is more likely because it also contains an abundant 1740-1800 Ma zircon component (Daly et al., 1998). However, it should be noted that there is no prominent source in Australia for the sparse ca.1490-1520 Ma grains.

\section{Yellowjacket Formation (Sample \#2; 13PL01; Fig. 6)}

We sampled the lowest sand bed in the Yellowjacket Formation southeast of Yellowjacket Lake, east of the Bighorn Crags pluton. Sample 13PL01 is a banded rock, composed of fine sand and silt couplets, and is petrographically a quartz arenite. The zircon grains are mostly less than 100 microns in length. Sixtytwo grains were analyzed, with a number of repeat analyses carried out to cross check the U-Pb data for the younger grains. Data are in Table 3B. There are a number of grains analyzed that 

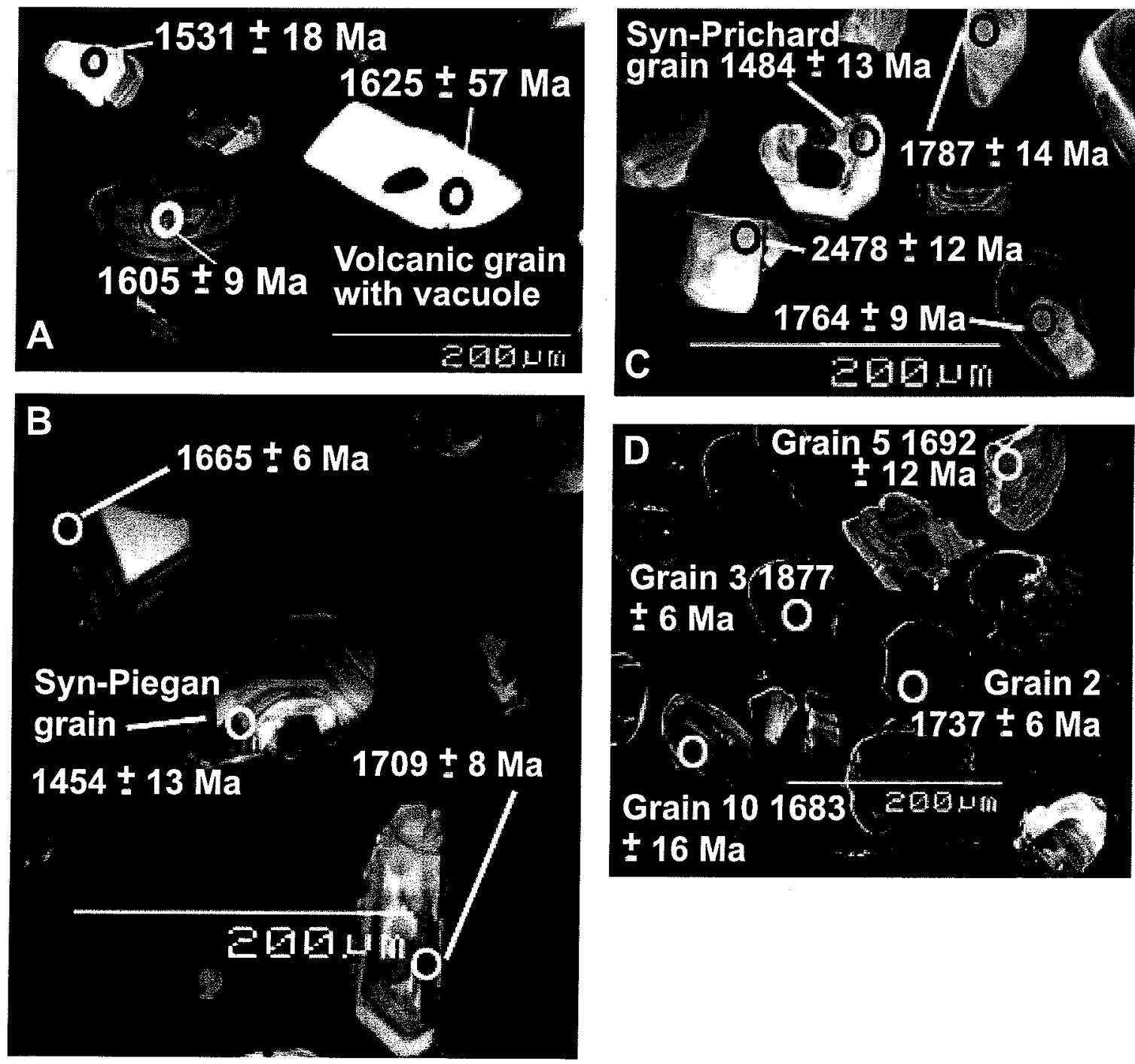

FIG. 4.-Cathodoluminescence images of detrital zircon grains from the several age populations in the Belt Supergroup. A) Prichard Fm., non-North American magmatic grains (1530 to $1625 \mathrm{Ma}$ ). B) Yellowjacket Fm., Paleoproterozoic and syn-Belt magmatic grains. C) Hoodoo Quartzite, 2478 and $1764 \mathrm{Ma}$ metamorphic grains; 1787 and 1484 (syn-Prichard) magmatic grains. D) Gunsight Fm. Beaverhead Impact Paleoproterozoic magmatic grains of the 1650-1780 Ma flood $(2,5,10)$ and intermediate older 1877 Ma grain (3).

yield significantly discordant $\mathrm{U}-\mathrm{Pb}$ data, and these are shown as shaded on the Wetherill plot and have been excluded from Fig. $6 \mathrm{~B}$. The majority of grains analyzed have ages in the Paleoproterozoic at $1600-1800 \mathrm{Ma}$, with a significant younger peak at $1450 \mathrm{Ma}$ and scattered older grains ranging to ca. 2585 $\mathrm{Ma}$. The dominant Paleoproterozoic age groupings are ca. 1675 and ca. $1720 \mathrm{Ma}$. Six grains form a coherent group with a weighted mean age of $1454 \pm 9 \mathrm{Ma}$, which is a maximum constraint on the depositional age (Fig. 6A). These age populations are fundamentally different from those of the Prichard Formation ("the Yellowjacket is not the Prichard"; Winston et al., 1999). Paleoproterozoic populations flood the Yellowjacket. The non-North American populations, which dominate the Prichard, are nearly absent (Table 2).

\section{Hoodoo Quartzite (Sample \# 3; 951Tz234; Fig. 7; and Sample \#4;02RL888; Fig. 8)}

We analyzed detrital zircons from two samples of strata included in the Hoodoo Quartzite. They have comparable age populations. Sample 95Itz234 of the Hoodoo was collected by R.G. Tysdal from west of Quartzite Mountain, stratigraphically above the Yellowjacket sample. Sixty grains were analyzed (Fig. 7; Table 3C). A second Hoodoo sample (02RL888) is from near Taylor Ranch on Big Creek, a tributary to the Middle Fork of the Salmon River. This is the westernmost sample location, in an area where the Mesoproterozoic strata are totally surrounded by younger intrusive rocks and stratigraphic relations are uncertain. Sixty-three grains were analyzed (Fig. 8; Table 3D). 

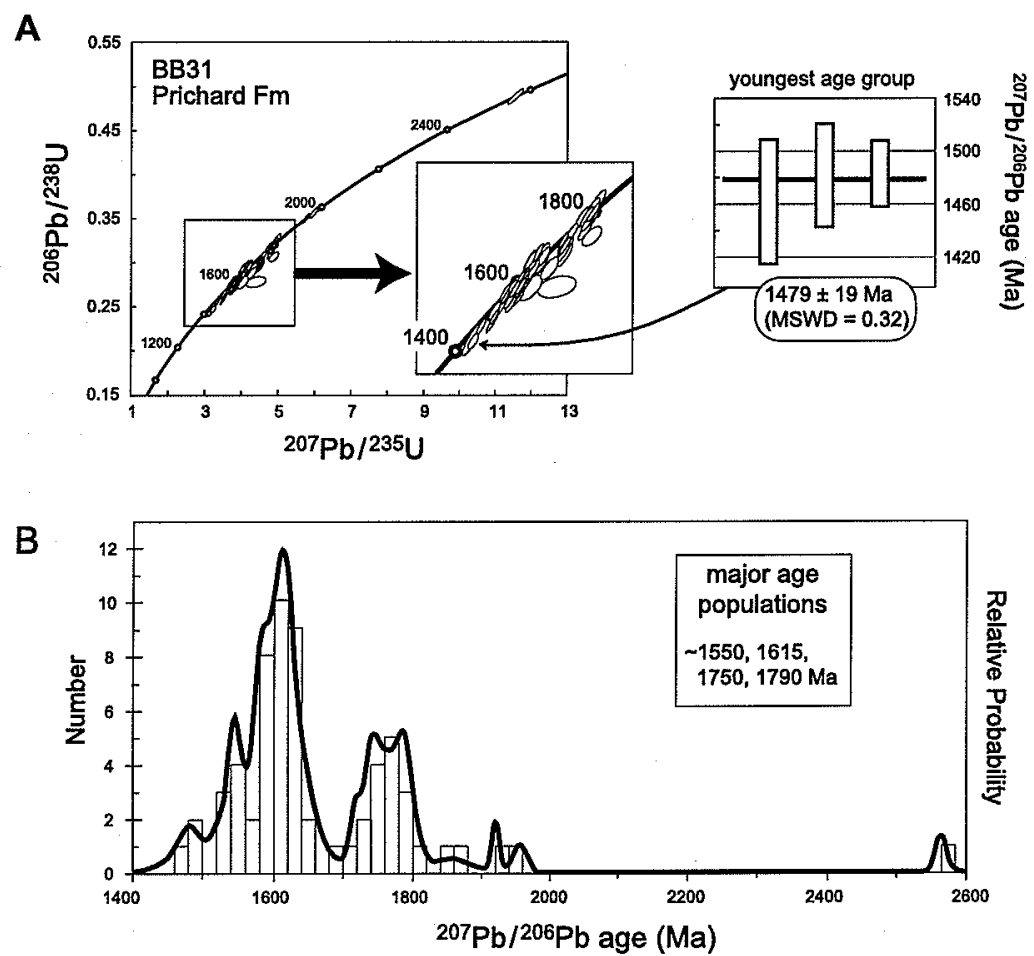

FIG. 5.-Ages of detrital zircons in sample BB31, Prichard Formation. A) Wetherill plot with enlargement of 1400 to $1800 \mathrm{Ma}$, and plot of youngest grain group. Filled ellipses are discordant analyses that were not used in the probability-age plot. B) Probability-age plot with major age populations listed.

Both samples contain a population of ca. 1450 grains $(1448 \pm$ $10 \mathrm{Ma}$ and $1445 \pm \mathrm{Ma}$ ) and $\mathrm{a}$ ca. $1670-1890 \mathrm{Ma}$ population. Other peaks are at 1725, 1750,1775, and $1790 \mathrm{Ma}$. The distinction of these peaks within the Paleoproterozoic flood is rather arbitrary. There are scattered older grains ranging to ca. $2700 \mathrm{Ma}$.

\section{Apple Creek Formation (Sample \#5; SS95-19; Fig. 9)}

We sampled a banded siltite unit of the Apple Creek Formation from mineralized drill core in the Blackbird mining district (drillhole from the Sunshine Prospect of Formation Capital Inc., collected by Bill Scales). The sample is from a subsurface interval containing biotitite thought to be a synsedimentary tuff (Hahn and Hughes, 1984; Nash and Hahn, 1989). To the north, these strata are intruded by 1370 Ma plutons, providing a minimum age (Doughty and Chamberlain, 1996; Evans and Green, 2003; Lund and Tysdal, this volume). Seventy-nine grains were analyzed (Fig. 9; Table 3E). Three syn-Belt grains yield an imprecise weighted mean ${ }^{207} \mathrm{~Pb} /{ }^{206} \mathrm{~Pb}$ age of $1446 \pm 36 \mathrm{Ma}$. Once again the detrital zircon age spectrum is dominated by Paleoproterozoic components, with major age populations at ca. 1680, 1740, and $1820 \mathrm{Ma}$. There are scattered older grains ranging to ca. $2665 \mathrm{Ma}$.

Western Gunsight Formation (Sample \#6; 39PL02; Fig. 10)

We sampled flat-laminated iron-stained fine sandstone of the lowermost Gunsight Formation from the Haynes Stellite mine in the Blackbird district, Salmon River Mountains, Idaho. Sixty-one grains were analyzed (Fig. 10; Table 3F). The detrital zircons mostly have ages in the range $1580-1800 \mathrm{Ma}$, with populations at 1685,1725 , and $1780 \mathrm{Ma}$. A single grain with ${ }^{207} \mathrm{~Pb} /{ }^{206} \mathrm{~Pb}$ date of ca. $1410 \mathrm{Ma}$ is within uncertainty of concordia, but this is a single analysis and so has little geological significance. There are four grains in the 1510-1625 non-North American range, which is generally not present in the east-central Idaho strata. Scattered older grains are also present, with four grains in the range ca. $2455-2545 \mathrm{Ma}$

\section{Eastern Gunsight Formation from Beaverhead Impact Site (Sample \#7; 23PL92; Fig. 11)}

We analyzed zircons from hematitic subarkosic arenite from the Gunsight Formation from the Beaverhead impact locality at Island Butte, in southwest Montana (Hargraves et al., 1990; Hargraves et al., 1994; Fiske et al., 1994; Kellogg et al., 2003). Sixty grains were analyzed, a number in duplicate. The data are shown in Figure 11 and Table 3G. The zircons are coarse grained and mostly have simple oscillatory-zoned igneous internal structures (Fig. 4D).

The Beaverhead impact structure has been dated at $900 \mathrm{Ma}$ or younger by $\mathrm{Ar}-\mathrm{Ar}$ and $\mathrm{U}-\mathrm{Pb}$ isotopic studies of brecciated Paleoproterozoic gneiss (Kellogg et al., 2003). A feature of the analyses for this sample is the high degree of discordance. Twenty-six of the 65 areas analyzed are greater than $10 \%$ discordant, although it is probable that much of this discordance arises from loss of radiogenic $\mathrm{Pb}$ at or near the present day. The calculated radiogenic ${ }^{207} \mathrm{~Pb} /{ }^{206} \mathrm{~Pb}$ ages for the concordant mostly Paleoproterozoic zircons are interpreted to provide reasonable 

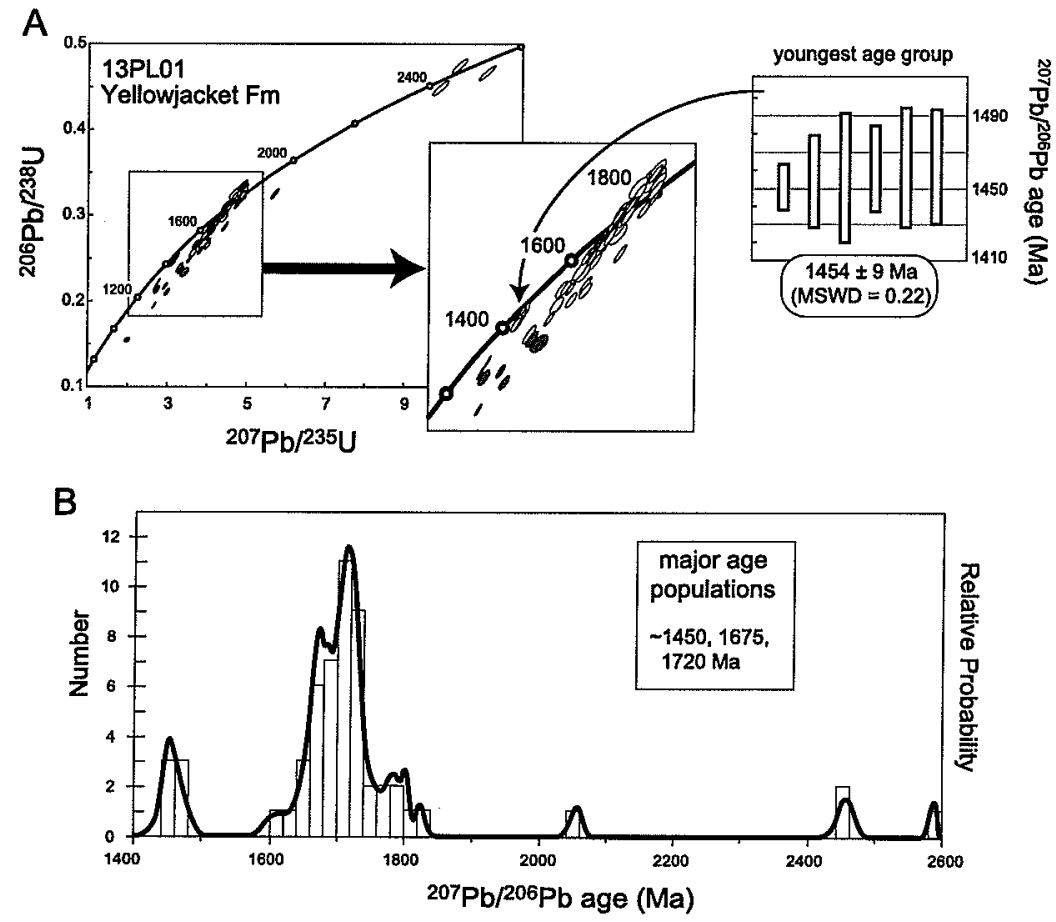

FIG. 6.-Detrital zircon ages from sample 13PL01; lowest sandstone in Yellowjacket Formation east of Yellowjacket Lake, Bighorn Crags. A) Wetherill plot with enlargement of 1400 to $1800 \mathrm{Ma}$, and plot of youngest grain group. Filled ellipses are discordant analyses that were not used in the probability-age plot. B) Probability-age plot with major age populations listed.

A

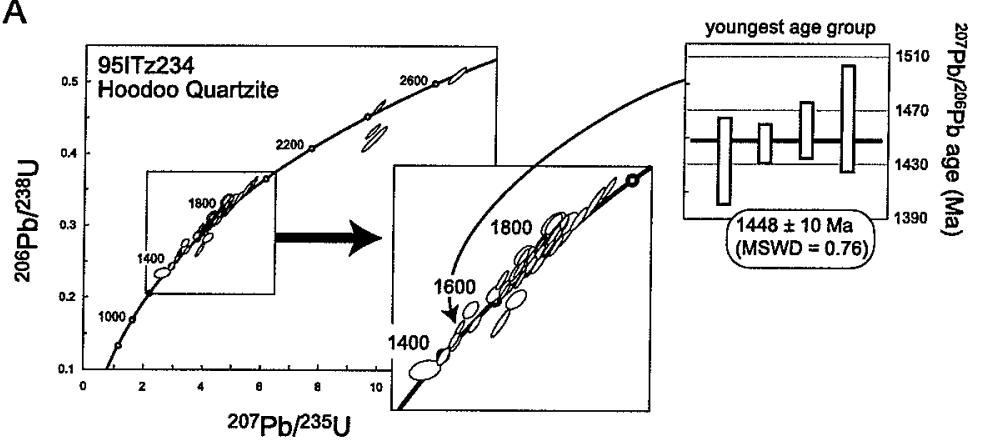

B

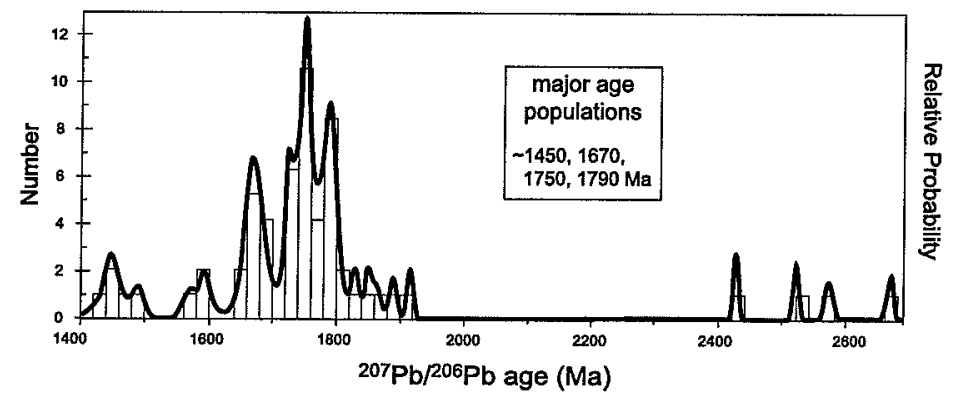

FIG. 7.-Detrital zircon ages from 951Tz234; Hoodoo Quartzite from Quartzite Mountain, collected by R.G. Tysdal and K. Lund, and data run by J. Aleinikoff. A) Wetherill plot with enlargement of 1400 to $1800 \mathrm{Ma}$, and plot of youngest grain group. Filled ellipses are discordant analyses that were not used in the Probability-Age plot. B) Probability-Age plot with major age populations listed. 

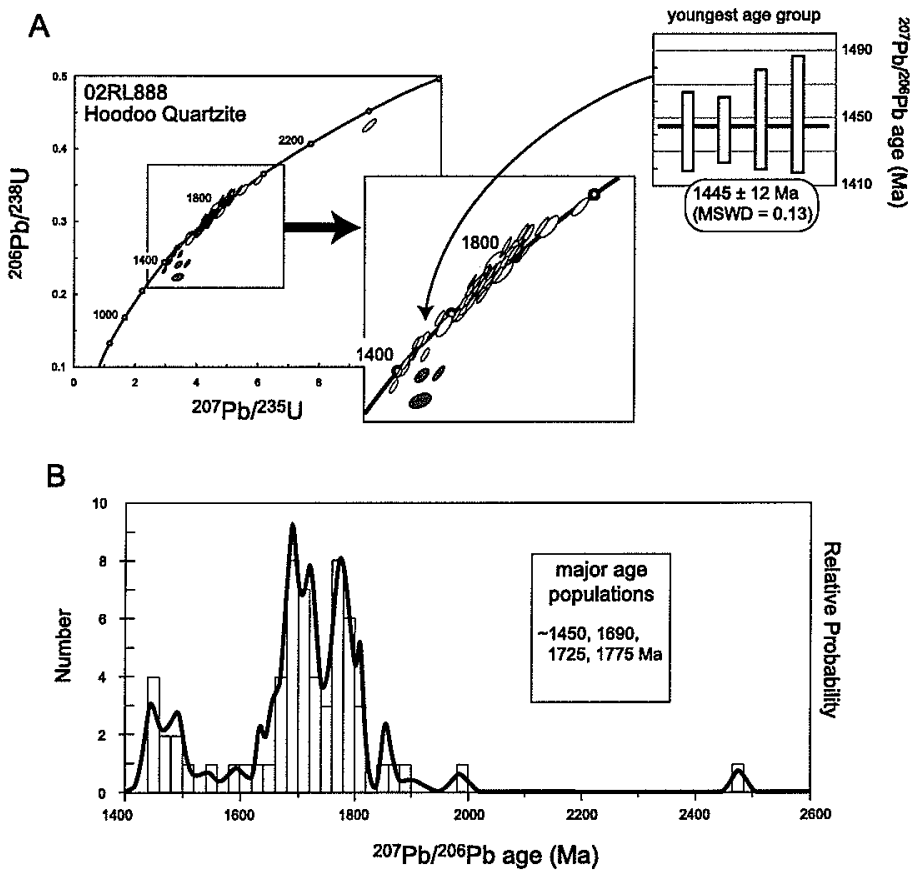

Fic. 8.-Detrital zircon ages from 02RL888; Hoodoo Quartzite from Taylor Ranch on Big Creek, west of the Middle ForkSalmon River, Salmon River Mountains. Sample collected by R. Lewis, Idaho Geological Survey. A) Wetherill plot with enlargement of 1400 to $1800 \mathrm{Ma}$, and plot of youngest grain group. Filled ellipses are discordant analyses that were not used in the probability-age plot. B) Probability-age plot with major age populations listed.

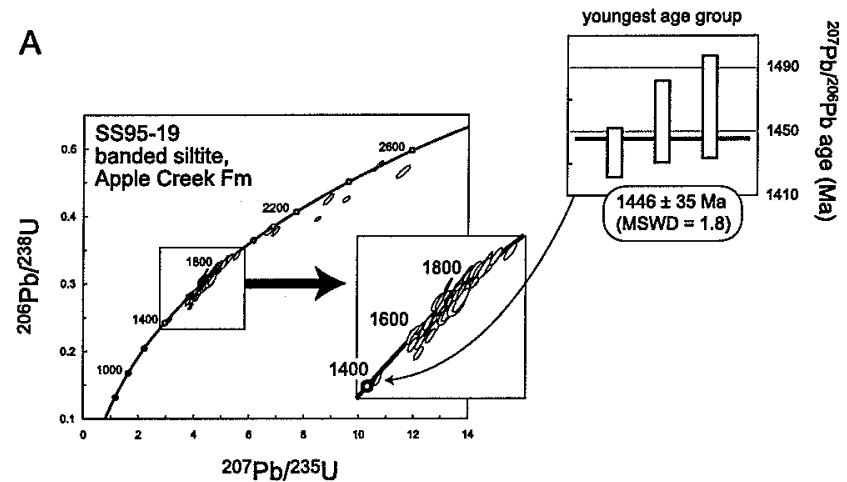

B

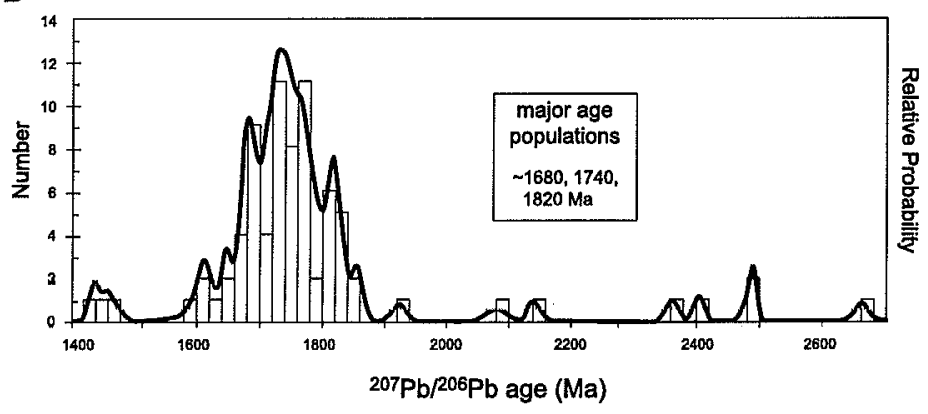

FIt. 9. Detrital-zircon are data from SS95A-19:a, banded siltite member of Apple Cretk Formation, frum Sunshine Prospect drill core, Blackbird mining district. A) Wetherill plot with enlargement of 1400 to $1800 \mathrm{Ma}$, and plot of youngest grain group. Filled ellipses are discordant analyses that were not used in the probability-age plot. B) Probability-age plut with ulajor age populations listed. 
A

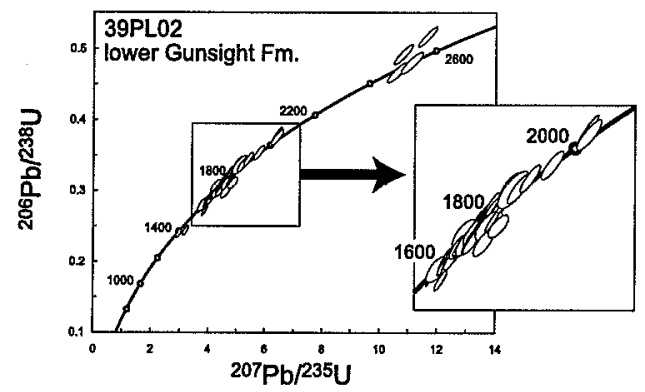

B

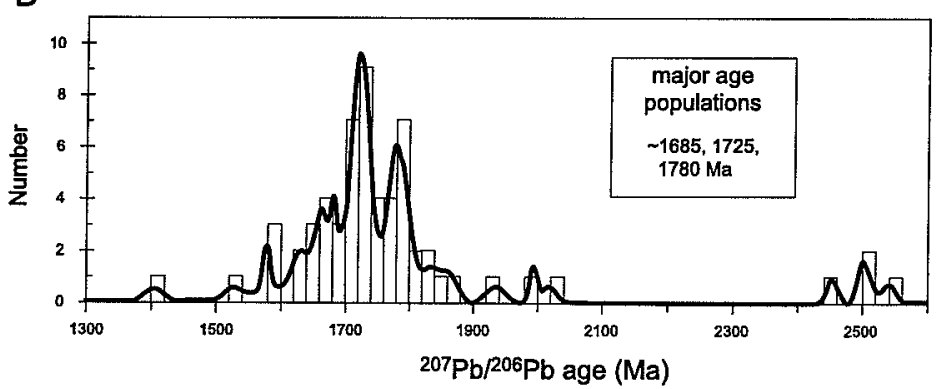

FIG. 10.-Detrital-zircon data from 39PL02, basal western Gunsight Formation, Haynes Stellite Prospect, Blackbird mining district. A) Wetherill plot with enlargement of 1400 to $1800 \mathrm{Ma}$. Filled ellipses are discordant analyses that were not used in the probabilityage plot. B) Probability-age plot with major age populations listed.
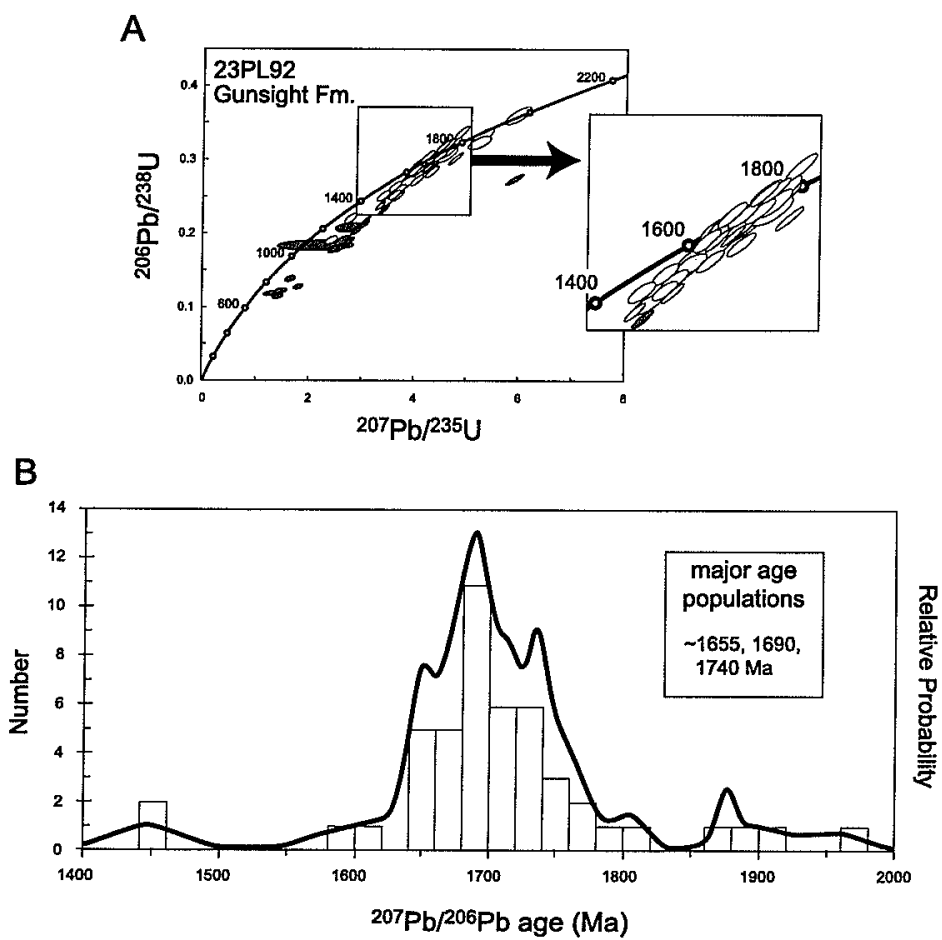

FIG. 11.-Detrital-zircon age data from 23PL92, Eastern Gunsight Formation with shattercones, from Island Butte, Beaverhead impact site, Beaverhead Mountains, Montana. A) Wetherill plot with enlargement of 1400 to $1800 \mathrm{Ma}$. Filled ellipses are discordant analyses that were not used in the probability-age plot. B) Probability-age plot with major age populations listed. 
estimates for their primary crystallization. The areas analyzed within the grains are mostly of good clear zircon, and are not metamict. Thus the loss of radiogenic $\mathrm{Pb}$ is anomalous in terms of the absence of obvious damage to the zircon crystals. Varying degrees of shock deformation are apparent in zircons affected by shock metamorphism, and transported afterward (Krogh et al., 1993; Kamo and Krogh, 1995; Kamo et al., 1996). The Beaverhead impact zircons show the $\mathrm{Pb}$ loss that would be expected, but not the shock-deformation features.

From the probability-density plot of the more concordant analyses it can be seen that the majority lie in the Paleoproterozoic, with groupings at ca. 1655, 1690, and $1740 \mathrm{Ma}$. There are a few older analyses up to ca. $1960 \mathrm{Ma}$. Analyses younger than $1600 \mathrm{Ma}$ are all discordant, though it should be noted that two of these have ${ }^{207} \mathrm{~Pb} /{ }^{206} \mathrm{~Pb}$ dates of about $1450 \mathrm{Ma}$.

\section{Swauger Formation (Sample \#8; 951Tz101; Fig. 12)}

The Swauger Formation was sampled along the Salmon River by R.G. Tysdal (U.S.G.S.). Sixty grains were analyzed; the data are shown in Figure 12 and Table $3 \mathrm{H}$. The detrital zircons in this sample contain the same Paleoproterozoic populations as the eastern Gunsight Formation, with groupings at ca. 1680, 1720, and $1760 \mathrm{Ma}$. Syn-Belt and non-North American grain populations are not present. Scattered older Paleoproterozoic and Archean grains are present.

\section{DISTRIBUTION OF GRAIN POPULATIONS}

Table 2 and Figure 13 contain a summary of the grain age populations from our samples in comparison to data from the
Revett and Wallace formations and the Missoula Group (Bonner, Mt. Nelson, and Mt. Shields formations) from Ross et al. (1991), Ross et al. (1992), and Ross and Villeneuve (2003). The previous data are shown on Table 2 in italics.

\section{Lower Belt and Ravalli Group Zircon Populations}

The Prichard Formation contains a syndepositional zircon population at $1480 \mathrm{Ma}$, two non-North American populations at about 1550 and $1615 \mathrm{Ma}$, and two older groupings, at 1750 and $1790 \mathrm{Ma}$. The Revett Quartzite of the Ravalli Group (Table 2; data from Ross and Villeneuve, 2003) contains non-North American populations at 1500 and $1610 \mathrm{Ma}$ and a Paleoproterozoic population at $1790 \mathrm{Ma}$. Facies relations are in accord with these detritalzircon data and suggest that the Ravalli Group in western Montana had the same source area as the Prichard Formation.

\section{Piegan and Lemhi Group Grain Populations}

The Yellowjacket, Hoodoo, Apple Creek, and western Gunsight samples from east-central Idaho have syn-Belt populations at $1450 \mathrm{Ma}$, multiple populations within the Paleoproterozoic flood of zircons, at $1655-1675 \mathrm{Ma}, 1680-1690 \mathrm{Ma}, 1710-1725 \mathrm{Ma}$ $1740-1760 \mathrm{Ma}$, and 1775-1790 Ma. Only the western Gunsight Formation contains populations in the North American magmatic gap, at 1580 and $1630 \mathrm{Ma}$. Zircons in the Wallace Formation are comparable (Fig. 13), and contain a non-North American grouping at $1540 \mathrm{Ma}$, and Paleoproterozoic populations at 1680 and $1750 \mathrm{Ma}$.

The eastern Gunsight (Beaverhead impact) and Swauger formations contain only the Proterozoic populations, with peaks at

A

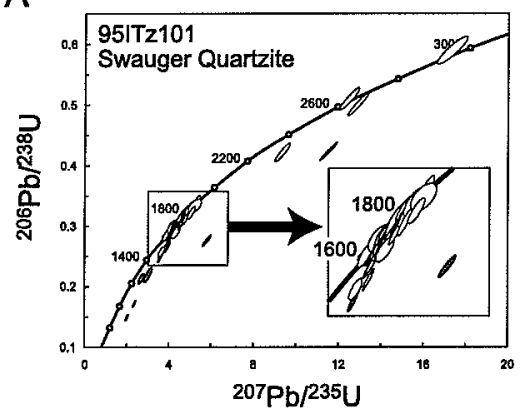

B

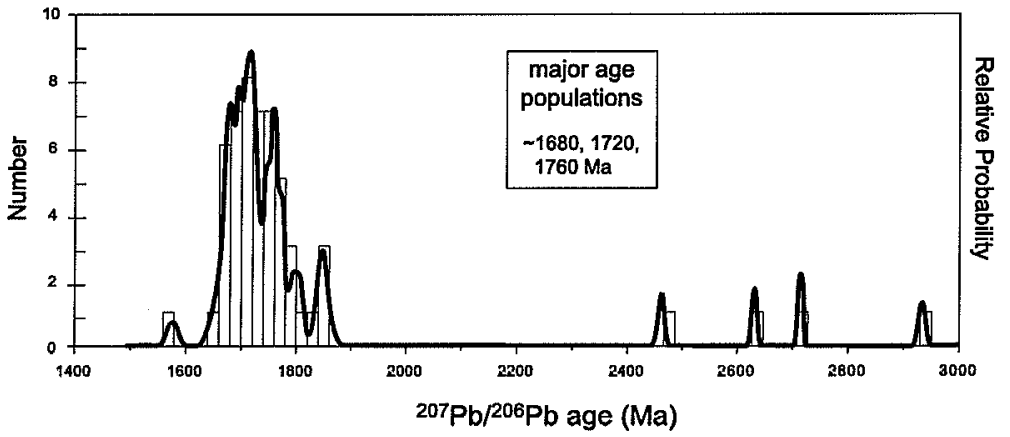

FIG, 12.-Detrital-zircon age data from Sample 951Tz101, Swauger Formation, Salmon River Canyon south of Salmon, Idaho, collected by R.G. Tysdal and analyzed by f. Aleinikoff. A) Wetherill plot with enlargement of 1400 to $1800 \mathrm{Ma}$. Filled ellipses are discordant analyses that were not used in the probability-age plot. B) Probability-age plot with major age populations listed. 

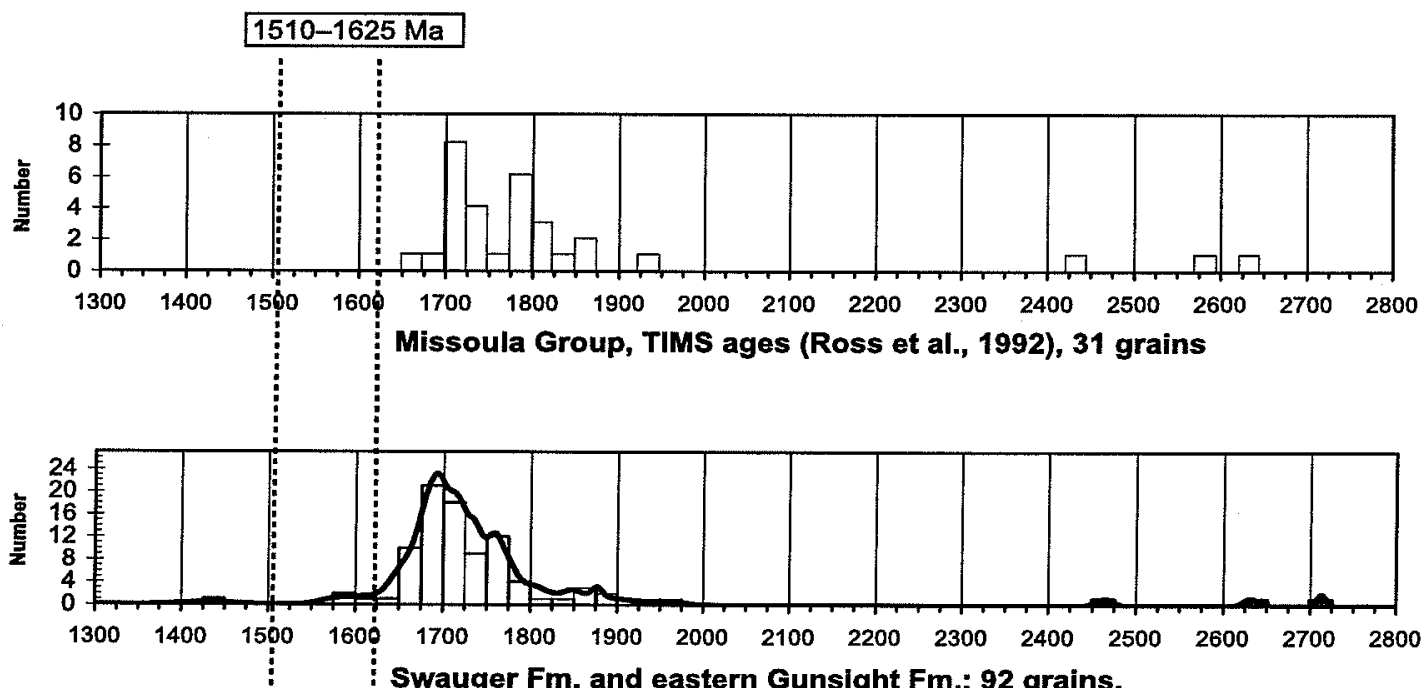

Swauger Fm. and eastern Gunsight Fm.; 92 grains,

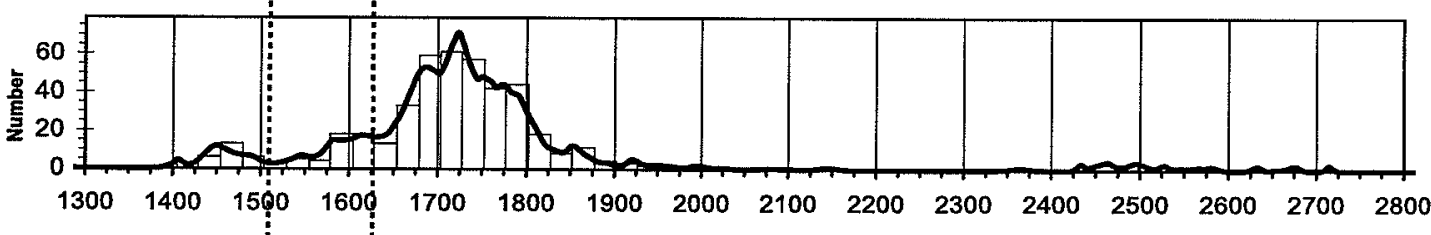

Yellowjacket, Hoodoo, Apple Creek, western Gunsight Fms., 417 grains

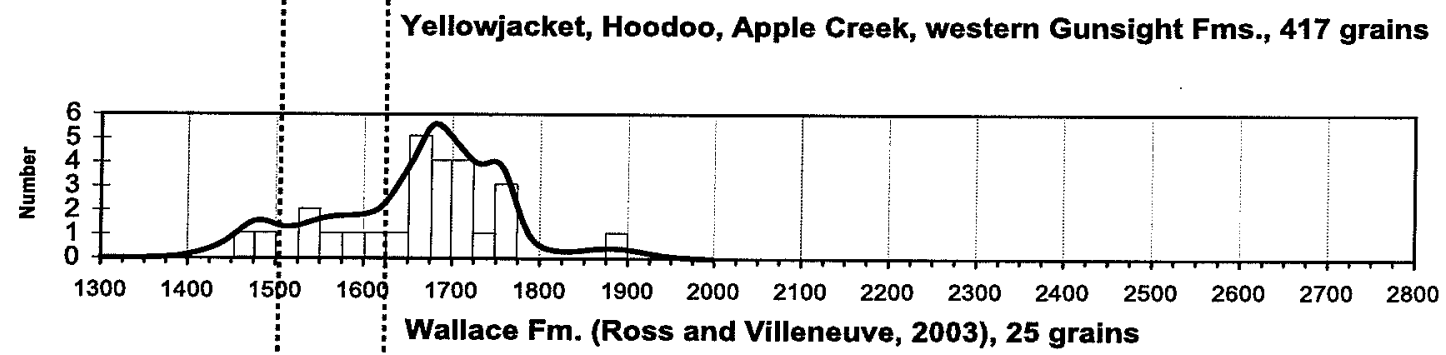

Wallace Fm. (Ross and Villeneuve, 2003), 25 grains
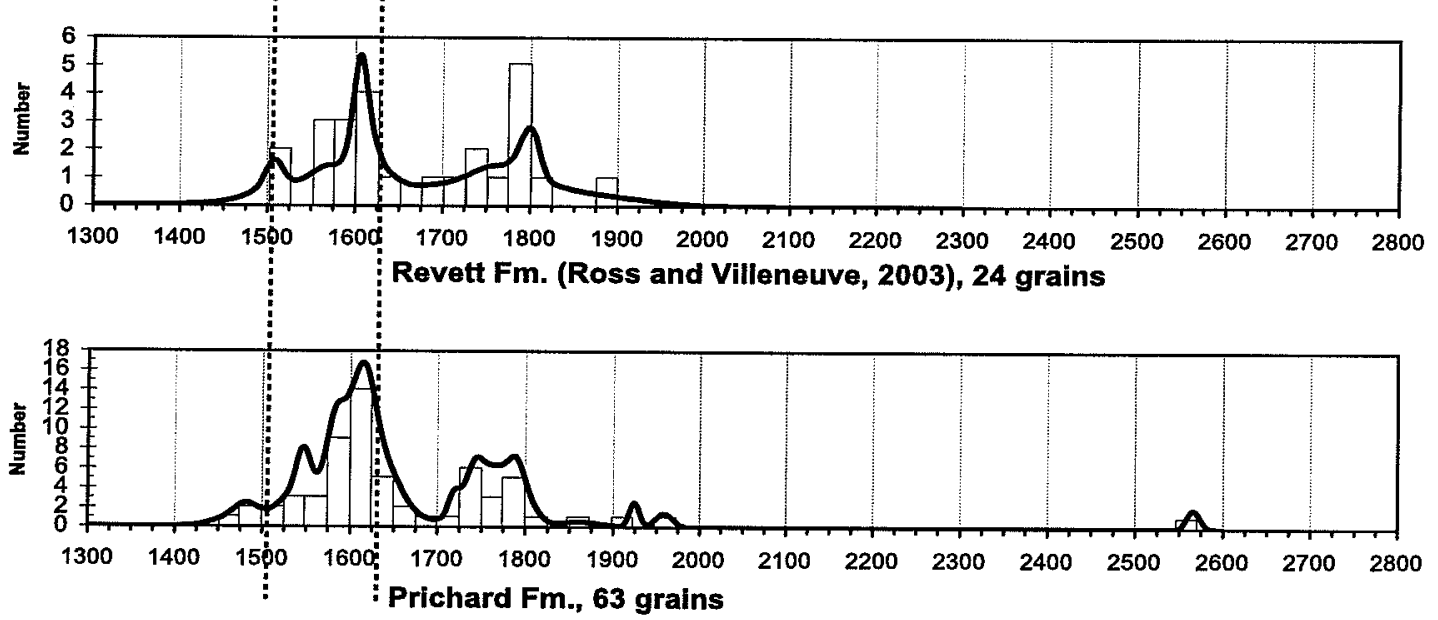

FIG. 13.-Detrital-zircon data from this paper combined with Revett and Wallace Formation data (Ross and Villeneuve, 2003), and the Bonner, Mt. Shields, and Mount Nelson formations of the Missoula Group (Ross et al., 1991; Ross et al., 1992). Minimum and maximum ages on non-North American grains are shown by dashed lines at 1510 and $1625 \mathrm{Ma}$. The probability-frequency curve for Missoula Group strata is not shown because it covers up histogram data. 
1665, 1680-1689, 1720, and 1750-1760 Ma. The Missoula Group contains Paleoproterozoic populations at 1710 and $1780 \mathrm{Ma}$ and lacks younger zircons. Its signature is thus similar to that of the eastern Gunsight and Swauger formations.

\section{TECTONIC MODEL}

Our data are consistent with a tectonic scenario (Fig. 14) based on the continental reconstruction of Sears and Price (2003) where western, non-North American source terranes fed the Prichard and Ravalli Groups of the northwestern part of the main Belt basin starting around $1470 \mathrm{Ma}$. This lower Belt clastic wedge contains Paleoproterozoic zircons with age peaks at 1750 and $1780 \mathrm{Ma}$, non-North American zircons with peaks at 1500, 1550, and $1610-1615 \mathrm{Ma}$, and Paleoproterozoic populations at 1750 and $1790 \mathrm{Ma}$.

A different set of detrital-zircon age populations characterizes the middle Belt Supergroup (Piegan Group) and the Yellowjacket, Apple Creek, and western Gunsight formations.
This clastic wedge mainly lacks the non-North American populations, although a few 1510-1630 Ma grains are present. Further the unmixed peaks of the Paleoproterozoic flood include younger populations not present in the Prichard Formation, at 1655-1670, 1680-1690, and 1710-1725 Ma.

The Missoula Group lacks syn-Belt and non-North American zircon grains and contains the same Paleoproterozoic populations as the eastern Gunsight and Swauger formations at 1710$1720 \mathrm{Ma}, 1740-1760 \mathrm{Ma}$, and $1780 \mathrm{Ma}$.

\section{CONCLUSIONS}

Our data yield several specific stratigraphic and tectonic conclusions:

1. The Yellowjacket Formation is younger than $1454 \pm 9 \mathrm{Ma}$. The Yellowjacket contains a different set of detrital-zircon age populations than the lower Belt Prichard Formation (Winston et al., 1999), lacking major non-North American grain popu-

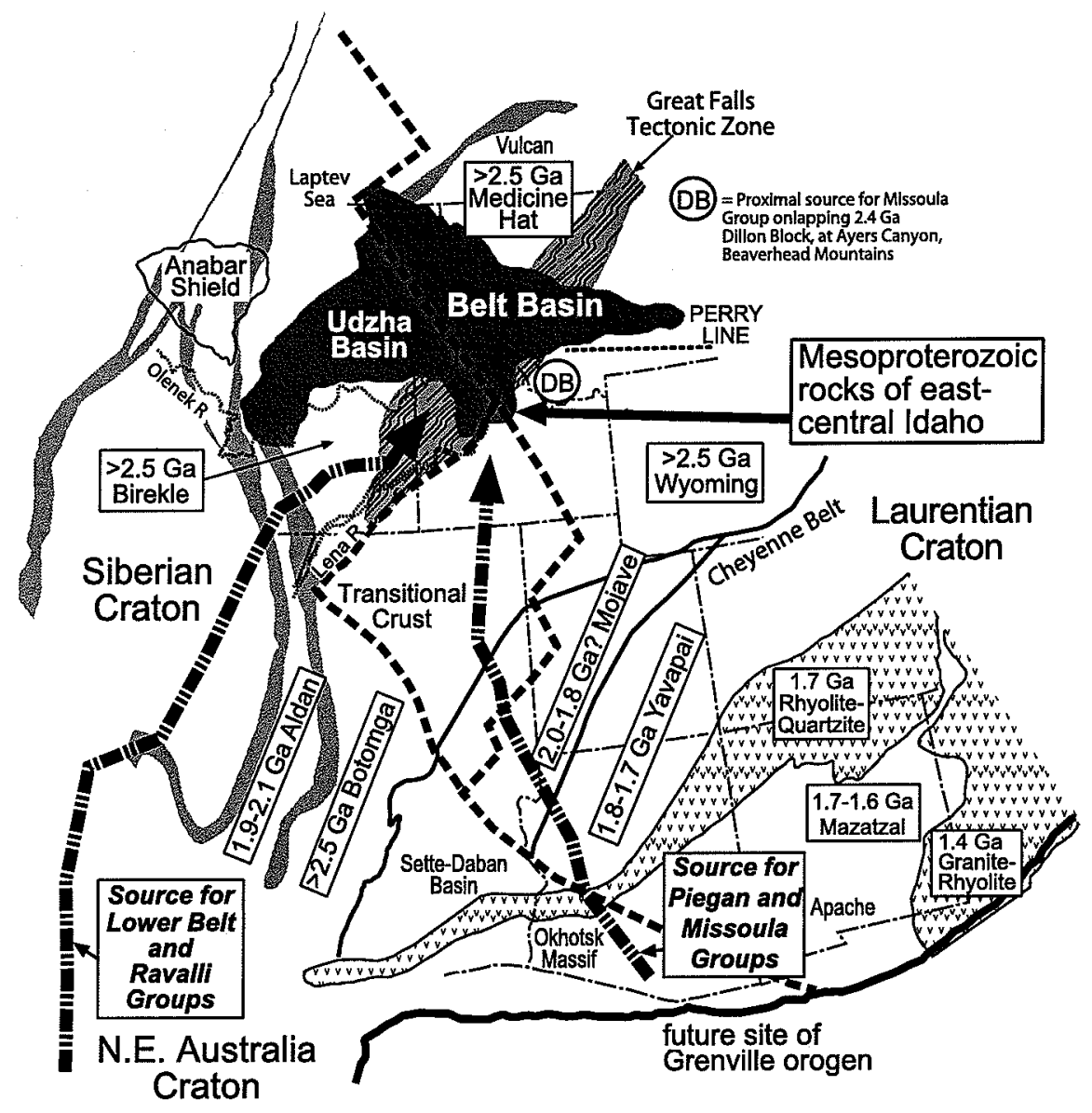

FIG. 14.- Tectonic synthesis map showing Laurentian Paleoproterozoic age terranes (Karlstrom et al., 2001; Ross and Villeneuve, 2003), possible positions of Siberia and Australia (after Sears and Price, 2003, and Sears, this volume), and proposed big-river transport of lower and upper Belt Supergroup grain populations. The circled DB refers to pebbly Missoula Group strata overlying Paleoproterozoic gneiss of the Dillon Block, Great Falls tectonic zone in the Beaverhead Range. This was a proximal source for at least some of the Paleoproterozoic zircon populations. Non-North American grains in lower Belt Supergroup may have come from North Queensland, Australia. The bulk of Paleoproterozoic Laurentian grains are shown as coming from the Yavapai and Mazatzal provinces. 
lations. Instead, the Yellowjacket contains the same Paleoproterozoic flood of grains as the Hoodoo Quartzite west of the Iron Lake Fault, and the Apple Creek and western Gunsight formations east of that fault.

2. The Hoodoo Quartzite, which stratigraphically overlies the Yellowjacket, is younger than $1448 \pm 10 \mathrm{Ma}$ or $1445 \pm 12 \mathrm{Ma}$, and has basically the same grain populations as the Yellowjacket. The two Hoodoo samples, from widely separated locations, contain the same sets of detrital-zircon grain populations, suggesting that the formation designation is viable.

3. East of the Iron Lake Fault, the Apple Creek Formation in the Blackbird Mining District is younger than $1446 \pm 35 \mathrm{Ma}$ and contains detrital-zircon grain populations similar to those of the Yellowjacket and Hoodoo formations west of the fault. The 1450 Ma grain population in Yellowjacket, Hoodoo, and Apple Creek Formation strata overlaps the age for the $1454 \pm$ 9 Ma tuff in the upper Piegan Group in Glacier National Park. Because this tuff is near the top of the Piegan Group, the Yellowjacket, Hoodoo, and Apple Creek formations must be coeval with or younger than the bulk of the Helena and Wallace formations.

4. The correlation of the upper Apple Creek Formation with the upper Piegan Group, first proposed by Ruppel (1975), and supported by Winston et al. (1999), and the presence of ca. $1450 \mathrm{Ma}$ zircons in the Yellowjacket, Hoodoo, and Apple Creek strata of east-central Idaho, requires deposition of these strata in about $10 \mathrm{My}$ (between about 1455 and 1445 $\mathrm{Ma}$ ). Evidence for rapid deposition includes normal faulting that produced the Apple Creek diamictite, presence of riftrelated sedimentary exhalative copper-cobalt mineralization in the Blackbird district, and the cyclic sedimentology with no reported stratigraphic sequence boundaries in the Apple Creek and Gunsight formations. If the 55-meter-scale carbonate-siliciclastic cycles of the upper unit of the Apple Creek Formation at Yellow Lake represent fifth-order parasequences with ca. $10^{4}$ year duration (Vail et al., 1977), then that $300 \mathrm{~m}$ of strata could have accumulated in 0.55 million years. Extrapolation of this maximum sedimentation rate of $300 \mathrm{~m}$ per 550,000 years to the $10 \mathrm{~km}$ total east-central Idaho section yields a minimum depositional span of $18 \mathrm{My}$, which is of the same scale as the precision on the U-Pb ages.

5. The stratigraphic tie between the Lemhi Group and the Belt Supergroup remains a matter of discussion among the authors. Physical continuity cannot be established, because the area is so broken by thrust faults. The similar detrital-zircon populations suggest a common source but do not demonstrate physical continuity at the time of deposition.

6. The eastern Gunsight and Swauger formations and the Missoula Group contain the same Proterozoic grain populations but lack syn-Belt grains. The correlation of those units seems reasonable. At least some of the sand in the undifferentiated Missoula Group or Gunsight Formation east of the Miner Lake-Beaverhead Divide fault zone came from proximal sources in the Dillon block of southwest Montana (shown as circled DB in Fig. 14) (Tysdal et al., 2005).

7. The great volume of the Paleoproterozoic zircon grain populations, the predominance of concentrically zoned magmatic zircons, and the generally fine-grained nature of the sand in the Lemhi Group suggest that voluminous distal sources supplied the bulk of the grains. These sources may have included juvenile crust of Colorado, Utah, and Arizona, south of the Cheyenne Belt. The proposed transport systems are shown with large arrows in Figure 14.

Further study of zircons in the Belt Supergroup and Mesoproterozoic strata of east-central Idaho will test our hypotheses and better define the isotopic character of zircon populations of known age. Such data could demonstrate the Laurentian or exotic affinity of the several detrital-zircon age populations.

\section{ACKNOWLEDGMENTS}

This research was supported by National Science Foundation grant EAR 0125756, by an Idaho State University Faculty Research Committee grant to P.K. Link, and by the Mineral Resources Program, U.S. Geological Survey. The work was initiated while Link was on sabbatical leave at Australian National University in 2002-2003. The assistance of many people at Research School of Earth Sciences is gratefully acknowledged. We received willing and generous help in mineral separation from Kaleb Scarberry at Idaho State University, Rich Friedman and Jim Mortensen at University of British Columbia, and Ezra Yacob at U.S.G.S. The manuscript was reviewed and drastically improved by comments from Don Winston, Russ Burmester, Gerry Ross, Karl Evans, Art Bookstrom, and J. Michael O'Neill.

\section{REFERENCES}

ANDERSON, H.E., AND DAVIS, D.W., 1995, U-Pb geochronology of the Moyie sills, Purcell Supergroup, southeastern British Columbia: implications for Mesoproterozoic geological history of the Purcell (Belt) basin: Canadian Journal of Earth Sciences, v. 32, p. 1180-1193.

ANDERSON, J.L., 1989, Proterozoic anorogenic granites of the southwestern United States, in Jenny, J.P., and Reynolds, S., eds., Geologic Evolution of Arizona: Tucson, Arizona Geological Digest, v. 17, p. 211-238.

ANDERSON, J.L., AND Morrison, J., 2005, Ilmenite, magnetite, and peraluminous Mesoproterozoic anorogenic granites of Laurentia and Baltica: Lithos, v. 80, p. 45-60.

ARMSTRONG, R.L., 1975, Precambrian (1500 m.y. old) rocks of central Idaho-the Salmon River Arch and its role in Cordilleran sedimentation and tectonics: American Journal of Science, v. 275-A, p. 437467.

Barth, A.P., Wooden, J.L., Coleman, D.S., and Fanning, C.M., 2000, Geochronology of the Proterozoic basement of southwestern North America, and the origin and evolution of the Mojave crustal province: Tectonics, v. 19, p. 616-685.

Blewett, R.S., Black, L.P., SUn, S.-S, KNutson, J., Hutton, L.J., ANd Bain, J.H.C., 1998, U-Pb zircon and Sm-Nd geochronology of the Mesoproterozoic of north Queensland: Implications for a Rodinia connection with the Belt Supergroup of North America: Precambrian Research, v. 89, p. 101-127.

BURGER, H.R., 2004, General geology and tectonic setting of the Tobacco Root Mountains, in Brady, J.B., Burger, H.R., Cheney, J.T., and Harms, T.A., eds., Precambrian Geology of the Tobacco Root Mountains, Montana: Geological Society of America, Special Paper 377, p $1-14$.

ChAmberLAIN, K.R., 1988, The Medicine Bow orogeny: Timing of deformation and model of crustal structure produced during continent-arc collision, ca. $1.78 \mathrm{Ga}$, southeastern Wyoming: Rocky Mountain Geology, v. 33, p. 259-278.

CRESSMAN, E.R., 1989, Reconnaissance stratigraphy of the Prichard Formation (Middle Proterozoic) near Plains, Sanders County, Montana: U.S Geological Survey, Professional Paper 1490, 80 p. 
DALY, S.J., FANNING, C.M., AND FAIRCLOUGH, M.C., 1998, Tectonic evolution and exploration potential of the Gawler Craton: AGSO (Australian Geological Survey Organization), Journal of Australian Geology and Geophysics, v. 17, p. 145-168.

Dodson, M.H., Compston, W., WILliams, I.S., AND WILSON, J.F., 1988, A search for ancient detrital zircons in Zimbabwean sediments: Geological Society of London, Journal, v. 145, p. 977-983.

DOUGHTY, P.T., AND Chamberlain, K.R., 1996, Salmon River Arch revisited new evidence for $1370 \mathrm{Ma}$ rifting near the end of deposition in the Middle Proterozoic Belt basin: Canadian Journal of Earth Sciences, $v$. 33, p. 1037-1052.

DOVER, J.H., 1981, Geology of the Boulder-Pioneer Wilderness Study Area, Blaine and Custer Counties, Idaho: U.S. Geological Survey, Bulletin 1497, p. 1-75.

DOVER, J.H., 1983, Geologic map and sections of the central Pioneer Mountains, Blaine and Custer Counties, central Idaho: U.S. Geological Survey, Miscellaneous Investigations Series, Map I-1319, scale 1:48,000

Duebendorfer, E.M., Chamberlain, K.R., AND Jones, C.S., 2001 Paleoproterozoic tectonic history of the Cerbat Mountains, northwestern Arizona: Implications for crustal assembly in the southwestern United States: Geological Society of America, Bulletin, v. 113, p 575-590.

EKREN, E.B., 1988, Stratigraphic and structural relations of the Hoodoo Quartzite and Yellowjacket formation of Middle Proterozoic age from Hoodoo Creek eastward to Mount Taylor, central Idaho: U.S. Geological Survey, Bulletin 1570, $17 \mathrm{p}$

ELSTON, D.E., AND LINK, P.K., 1993, Depositional and tectonic synthesis, in Reed, J., Simms, P., Houston, R., Rankin, D., Link, P., Van Schmus, R., and Bickford, P., eds., Precambrian: Conterminous U.S.: Geological Society of America, Decade of North American Geology, The Geology of North America, v. C-3, p. 569-575.

ELSTON, D.P., ENKIN, R.J., BAKER, J., AND KISLEVSKY, D.K., 2002, Tightening the Belt: Paleomagnetic-stratigraphic constraints on deposition, correlation, and deformation of the Middle Proterozoic (ca. 1.4 Ga) BeltPurcell Supergroup, United States and Canada: Geological Society of America, Bulletin, v. 114, p. 619-638.

Evans, K.V., 1998, The Yellowjacket Formation of East-Central Idaho, in Berg, R.B., ed., Belt Symposium III: Montana Bureau of Mines and Geology, Special Publication 112, p. 17-30.

Evans, K.V., Aleinikoff, J.N., Obradovich, J.D., and Fanning, C.M., 2000, SHRIMP U-Pb geochronology of volcanic rocks, Belt Supergroup, western Montana: evidence for rapid deposition of sedimentary strata: Canadian Journal of Earth Sciences, v. 37, p. 1287-1300.

Evans, K.V., AND GreEN, G.G., compilers, 2003, Geologic Map of the Salmon National Forest and Vicinity, East-Central Idaho: U.S. GeologicalSurvey, Geologic Investigations Series, MapI-2765, two sheets, scale 1:100,000.

EvANS, K.V., AND ZARTMAN, R.E., 1990, U-Th-Pb and Rb-Sr geochronology of Middle Proterozoic granite and augen gneiss, Salmon River Mountains, east-central Idaho: Geological Society of America, Bulletin, v. 102, p. 63-73.

FAROOQUI, M.A., 1994, Petrology and provenance of the Middle Proterozoic Bonner Formation and its correlatives, Belt Supergroup, Montana, Idaho, and Washington (unpublished Ph.D. Dissertation): University of Montana, Missoula Montana, $262 \mathrm{p}$

Fiske, P. Hargraves, R.B. Onstott, T.C., Koeberl, C, and Hougen, S.B. 1994, Pseudotachylites of the Beaverhead impact structure: geochemical, geochronological, petrographic, and field investigations, in Dressler, B.O., Grieve, R.A.F., and Sharpton, V.L., eds., Large Meteorite Impacts and Planetary Evolution: Geological Society of America, Special Paper 293, p. 163-176.

Foster, D.A., AND FANNING, C.M., 1997, Geochronology of the northern Idaho batholith and Bitterroot metamorphic core complex: Magmatism preceding and contemporaneous with extension: Geological Society of America, Bulletin, v. 109, p. 379-394.
Frost, B.R., Avchenko, O.V., Chamberlain, K.R., AND FRost, C.D., 1998 Evidence for extensive Proterozoic remobilization of the Aldan shield and implications for Proterozoic plate tectonic reconstructions of Siberia and Laurentia: Precambrian Research, v. 89, p. 1-23.

Frost, C.D., AND Frost, B.R., 1997, Reduced rapakivi type granites: The tholeiite connection: Geology, v. 25, p. 647-650.

Frost, C.D., AND WINSTON, D., 1987, Nd Isotope systematics from coarseand fine-grained sediments: Examples from the Middle Proterozoic Belt-Purcell Supergroup: Journal of Geology, v. 95, p. 309-327.

HAHN, G.A., AND HUGHES, G.J., JR., 1984, Sedimentation, tectonism, and associated magmatism of the Yellowjacket Formation in the Idaho Cobalt Belt, Lemhi County, Idaho, in Hobbs, S.W., ed., The Belt: Montana Bureau of Mines and Geology, Special Publication 90, p. 6567.

Hargraves, R.B., Cullicott, C.E., Deffeyes, K.S., Hougen, S.B., Christiansen, P.P., AND FISKE, P.S., 1990, Shatter cones and shocked rocks in southwestern Montana: The Beaverhead impact structure: Geology, v. 18, p. 832-834.

Hargraves, R.B., Kellogg, K.S., FlSKe, P.S., AND Hougen, S.B., 1994, Allochthonous impact-shocked rocks and superposed deformations at the Beaverhead site, southwest Montana-possible crater roots buried in south-central Idaho, in Dressler, B.O., Grieve, R.A.F., and Sharpton, V.L., eds., Large Meteorite Impacts and Planetary Evolution: Geological Society of America, Special Paper 293, p. 225-236.

Harms, T.A., Brady, J.B., Burger, H.R., AND ChENEY, J.T., 2004, Advances in the geology of the Tobacco Root Mountains, Montana, and their implications for the history of the northern Wyoming province, in Brady, J.B., Burger, H.R., Cheney, J.T., and Harms, T.A., eds., Precambrian Geology of the Tobacco Root Mountains, Montana: Geological Society of America, Special Paper 377, p. 227-243.

HARRISON, J.E, GRIGGS, A.B., AND WELLS, J.D., 1974, Tectonic features of the Precambrian Belt basin and their influence on post-Belt structures: U.S. Geological Survey, Professional Paper 866, 15 p.

HoBBs, S.W., 1980, The Lawson Creek Formation of middle Proterozoic age in east-central Idaho: U.S. Geological Survey, Bulletin 1482-E, 12 p.

JACKSON, M.J., AND SOUTHGATE, P.N., 2000, Evolution of three unconformity-bounded sandy carbonate successions in the McArthur River region of northern Australia: the Lawn, Wide, and Doom Supersequences in a proximal part of the Isa Superbasin: Australian Journal of Earth Sciences, v. 47, p. 625-635.

JACKSON, M.J., SOUTHGATE, P.N., AND PAGE, R.W., 2000, Gamma-ray logs and $\mathrm{U}-\mathrm{Pb}$ zircon geochronology-Essential tools to constrain lithofacies interpretation of Paleoproterozoic depositional systems, in Grotzinger, J.P., and James, N.P., eds., Carbonate Sedimentation and Diagenesis in the Evolving Precambrian World: SEPM, Special Publication 67, p. $23-41$.

JANECKE, S.U., 1994, Sedimentation and paleogeography of an Eocene to Oligocene riftzone, Idaho and Montana: Geological Society of America, Bulletin, v. 106, p. 1083-1095.

Janecke, S.U., BlankenaU, J.J., VanDenburg, C.J., and Van Gosen, B.S., 2001, Map of normal faults and extensional folds in the Tendoy Mountains and Beaverhead Range, Southwest Montana and eastern Idaho: U.S. Geological Survey, Miscellaneous Field Studies Map MF2362, scale 1:100,000.

JANECKE, S.U., MCINTOSH, W., AND GOOD, S., 1999, Testing models of rift basins-Structure and stratigraphy of an Eocene-Oligocene supradetachment basin, Muddy Creek half graben, southwest Montana: Basin Research, v. 11, p. 143-167.

JaneCKe, S.U., VandendiuRG, C.J., and Blankenau, J.J., 1998, Geometry, mecharisms and significance of extensional folds from examples in the Rocky Mountain Basin-and-Range province, U.S.A.: Journal of Structural Geology, v. 20, p. 841-856.

JaneCKe, S.U., VanDenburg, C.J., Blankenau, J.J., AND M'Gonigle, J.W., 2000, Long-distance longitudinal transport of gravel across the Cordilleran thrust belt of Montana and Idaho: Geology, v. 28, p. 439-442. 
KAMO, S.L., AND KROGH, T.E, 1995, Chicxulub Crater source for shocked zircon crystals from the Cretaceous-Tertiary boundary layer, Saskatchewan: evidence from new U-Pb data: Geology, v. 23, p. 281284.

Kamo, L.L., Rermold, W.U., KROGH, T.E., AND Colluston, W.P., 1996, A 2.023 $\mathrm{Ga}$ age for the Vredefort impact event and a first report of shock metamorphosed zircons in pseudotachylitic breccias and granophyre: Earth and Planetary Science Letters, v. 144, p. 369-387.

Karlstrom, K.E., Ahall, K.I., Harlan, S.S., Williams, M.L., McLelland, J., AND GeISSMAN, J.W., 2001, Long-lived (1.8-1.0 Ga) convergent margin in southern Laurentia, its extensions to Australia and Baltica, and implications for refining Rodinia: Precambrian Research, v. 111, p. 5-30.

KARISTROM, K.E., AND BOWRING, S.A., 1988, Early Proterozoic assembly of tectonostratigraphic terranes in southwestern North America: Journal of Geology v. 96, p. 561-576.

KARLSTROM, K.E., AND BowRING, S.A., 1993, Proterozoic orogenic history of Arizona, in Reed, J.C., Jr., Bickford, M.E., Houston, R.S., Link, P.K., Rankin, R.W., Sims, P.K., and Van Schmus, W.R., eds., Precambrian: Conterminous U.S.: Geological Society of America, Decade of North American Geology, The Geology of North America, v. C-2, p. 188-211.

KelloGG, K.S., SNeE, L.W., AND UNRUH, D.M., 2003, The Mesoproterozoic Beaverhead Impact structure and its tectonic setting, Montana-Idaho: ${ }^{40} \mathrm{Ar} /{ }^{39} \mathrm{Ar}$ and $\mathrm{U} / \mathrm{Pb}$ Isotopic constraints: Journal of Geology, v. 111, p. 639-652.

KROGH, T.E., KaMO, S.L., AND BoHOR, B.F., 1993, Fingerprinting the K/T impact site and determining the time of impact by $\mathrm{U}-\mathrm{Pb}$ dating of single shocked zircons from distal ejecta: Earth and Planetary Science Letters, v. 119, p. 425-429.

Krogh, T.E., Kamo, S.L., Sharpton, V.L., Marin, L.E., and Hildebrand, A.R., 1993, U-Pb ages of single shocked zircons linking distal $\mathrm{K} / \mathrm{T}$ ejecta to the Chicxulub crater: Nature, v. 366, p. 731-734.

LewIS, R.S., KullsGaARd, T.H., BeNNETt, E.H., AND HAlL, W.E., 1987, Lithologic and chemical characteristics of the central and southeastern part of the southern lobe of the Idaho batholith, in Vallier, T.L., and Brooks, H.C., eds., Geology of the Blue Mountains region of Oregon, Idaho and Washington: The Idaho Batholith and Its Border Zone: U.S. Geological Survey, Professional paper 1436, p. 171-196.

Link, P.K., Christie-Blick, N., Devlin, W.J., Elston, D.P., Horodyski, R.J., Levy, M., Mrler, J.M.G., Pearson, R.C., Prave, A.R., Stewart, J.H., WINSTON, D., WRIGHT, L.A., AND WRUCKE, C.T., 1993, Middle and Late Proterozoic stratified rocks of the western U.S. Cordillera, Colorado Plateau, and Basin and Range province, in Reed, J.C., Jr., Bickford, M.E., Houston, R.S., Link, P.K., Rankin, R.W., Sims, P.K., and Van Schmus, W.R., eds., Precambrian: Conterminous U.S.: Geological Society of America, Decade of North American Geology, The Geology of North America, v. C-2, p. 463-595.

LiNK, P.K., FANNING, C.M., AND BERANEK, L.P., 2005, Reliability and longitudinal change of detrital-zircon age spectra in the Snake River system, Idaho and Wyoming: An example of reproducing the bumpy barcode: Sedimentary Geology, v. 182, p. 101-142.

Link, P.K., Winston, D., AND BoYACK, D., 2003, Stratigraphy of the Mesoproterozoic Belt Supergroup, Salmon River Mountains, Lemhi County, Idaho: Northwest Geology, v. 32, p. 124-133.

LuCCHITTA, B.K., 1966, Structure of Hawley Creek area, Idaho-Montana (Ph.D. thesis): University Park, Pennsylvanian State University, 203 p.

LUDWIG, K.R., 2001, SQUID 1.02, A User's Manual; Berkeley Geochronology Center, Special Publication, no. 2, 2455 Ridge Road, Berkeley, CA 94709 , U.S.A.

LUDWIG, K.R., 2003, Isoplot/ Ex version 3.0: A geochronological toolkit for Microsoft Excel: Berkeley Geochronology Center, Special Publication, no. 4, 2455 Ridge Road, Berkeley CA 94709, U.S.A.

LunD, K.I., 2004, Geology of the Payette National Forest and vicinity, west-central Idaho: U.S. Geological Survey, Professional Paper 1666A-B, 89 p.
McMannss, W.J., 1963, LaHood Formation: A coarse facies of the Belt Series in southwestern Montana: Geological Society of America, Bulletin, v. 74, p. 407-436.

McTeague, M.S., AND Schmitr, J.G., 2003, Facies analysis of the LaHood Formation, a Middle Proterozoic fan-delta deposit: Northwest Geology, v. 32, p. 214.

M'GoNIGLE, J.W., 1993, Geologic map of the Medicine Lodge Peak quadrangle, Beaverhead County, Southwest Montana: U.S. Geological Survey, Geologic Quadrangle Map GQ- 1724, scale 1:24,000.

M'GoNIGLE, J.W., 1994, Geologic map of the Deadman Pass quadrangle, Beaverhead County, Montana, and Lemhi County, Idaho: U.S. Geological Survey, Geologic Quadrangle Map GQ-1753, scale 1:24,000.

MogK, D.W., MuelLER, P.A., AND WoODEN, J.L., 1992, The nature of Archean terrane boundaries: An example from the northern Wyoming province: Precambrian Research, v. 55, p. 155-168.

Mueller, P.A., Burger, H.R., WoOden, J.L., Brady, J.B., Cheney, J.T., Harms, T.A., AND Heatheringron, A.L., 2005, Paleoproterozoic metamorphism in the northern Wyoming Province: Implications for the assembly of Laurentia: Journal of Geology, v. 113, p. 169-179.

Mueller, P.A., Heatherington, A.L., Kelly, D.M., WOOden, J.L., AND Mock, D.W., 2002, Paleoproterozoic crust within the Great Falls tectonic zone: Implications for the assembly of southern Laurentia: Geology, v. 30, p. $127-130$.

NASH, J.T., AND HAHN, B.A., 1989, Stratabound Co-Cu deposits and mafic volcaniclastic rocks in the Blackbird mining district, Lemhi County, Idaho, in Boyle, R.W., Brown, A.C., Jefferson, C.W., Jowett, E.C., and Kirkham, R.V., eds., Sediment-Hosted Stratiform Copper Deposits: Geological Association of Canada, Special Paper 36, p. 339-356.

O'NelLL, J.M., 1998, The Great Falls tectonic zone, Montana-Idaho: An Early Proterozoic collisional orogen beneath and south of the Belt Basin, in Berg, R.B., ed., Belt Symposium III-1993: Montana Bureau of Mines and Geology, Special Publication 112, p. 222-228.

O'NeILL, J.M., AND LOPEZ, D.L., 1985, Character and regional significance of the Great Falls tectonic zone, east-central Idaho and west-central Montana: American Association of Petroleum Geologists, Bulletin, v. 69, p. 437-447.

O'NerLL, R.L., AND PAVLIS, T.L., 1988, Superposition of Cenozoic extension on Mesozoic compressional structures in the Pioneer metamorphic core complex, central Idaho: Geological Society of America, Bulletin, v. 100, p. $1833-1845$

Obradovich, J.D., and Peterman, Z.E., 1968, Geochronology of the Belt Series, Montana: Canadian Journal of Earth Sciences, v. 5, p. 737-747.

PACES, J.B., AND MrLLER, J.D., 1993, Precise U-Pb ages of Duluth Complex and related mafic intrusions, northeastern Minnesota: Geochronological insights to physical, petrogenetic, paleomagnetic, and tectonomagmatic process associated with the $1.1 \mathrm{Ga}$ Midcontinent Rift System: Journal of Geophysical Research, v. 98, p. 13,997-14,013.

REED, J.C., JR., compiler, 1993, Map of Precambrian Rocks of the Conterminous United States and Some Adjacent Parts of Canada, in Reed, J.C., Jr., Bickford, M.E., Houston, R.S., Link, P.K., Rankin, R.W., Sims, P.K., and Van Schmus, W.R., eds., Precambrian: Conterminous U.S.: Geological Society of America, Decade of North American Geology, The Geology of North America, v. C-2, Plate 1.

RODGERS, D.W., AND JANECKE, S.U., 1992, Tertiary paleogeologicmaps of the western Idaho-Wyoming-Montana thrust belt, in Link, P.K., Kuntz, M.A., and Platt, L.B., eds., Regional Geology of Eastern Idaho and Western Wyoming: Geological Society of America, Memoir 179, p. 83-94.

Ross, C.P., 1934, Geology and ore deposits of the Casto quadrangle, Idaho: U.S. Geological Survey, Bulletin 854, 135 p.

Ross, G.M., PARRISH, R.R., AND DudAS, F.O., 1991, Provenance of the Bonner Formation (Belt Supergroup), Montana: Insights from U-Pb and Sm$\mathrm{Nd}$ analyses of detrital minerals: Geology, v, 19, p. 340-343.

Ross, G.M., PARrish, R.R., AND WINSTON, D., 1992, Provenance and U-Pb geochronology of the Mesoproterozoic Belt Supergroup (northwest- 
ern United States): implications for age of deposition and prePanthalassa plate reconstructions: Earth and Planetary Science Letters, v. 113, p. 57-76.

Ross, G.M., AND VILleneUve, M., 2003, Provenance of the Mesoproterozoic (1.45 Ga) Belt Basin (western North America): Another piece in the pre-Rodinia paleogeographic puzzle: Geological Society of America Bulletin, v. 115, p. 1191-1217.

RUPPEL, E.T., 1975, Precambrian Y sedimentary rocks in east-central Idaho: U.S. Geological Survey, Professional Paper 889-A, 23 p.

RuPPEL, E.T., 1986, The Lemhi Arch: A late Proterozoic and early Paleozoic landmass in central Idaho, in Peterson, J.A., ed., Paleotectonics and Sedimentation in the Rocky Mountain Region, United States: American Association of Petroleum Geologists, Memoir 41, p. 119-130.

Ruppel, E.T., 1994, Preliminary geologic map of the Tepee Mountain 7.5 minute quadrangle, Beaverhead County, Montana and Lemhi County, Idaho: Montana Bureau of Mines and Geology, Map 317, scale $1: 24,000$

RUPPEL, E.T., AND LOPEZ, D.A., 1984, The thrust belt in southwest Montana and east-central Idaho: U.S. Geological Survey, Professional Paper $1278,41 \mathrm{p}$

RuPpel, E.T., O'Nenl, J.M., AND LoPez, D.A., 1993, Geologic map of the Dillon $1^{\circ} \times 2^{\circ}$ quadrangle, Idaho and Montana: U.S. Geological Survey, Miscellaneous Investigations Series Map I-1083-H, scale 1:250,000.

SAMBRIDGE, M.S., AND COMPSTON, W., 1994, Mixture modeling of multicomponent data sets with application to ion-probe zircon ages: Earth and Planetary Science Letters, v. 128, p. 373-390.

SCHANDL, E.S., AND DAVIS, D.W., 2001, Geochronology of the Sullivan deposit: $\mathrm{U}-\mathrm{Pb}$ and $\mathrm{Pb}-\mathrm{Pb}$ ages of zircon and titanites, in Lydon, J.W. Slack, J.F., Hoy, T., and Knapp, M.E., eds., The Geological Environment of the Sullivan Deposit, British Columbia: Geological Association of Canada, Mineral Deposits Division, MDD Special Volume 1, $\mathrm{p}$. 111-120.

Sears, J.W., Chamberlain, K.R., and Buckley, S.N., 1998, Structural and U$\mathrm{Pb}$ geochronological evidence for $1.47 \mathrm{Ga}$ rifting in the Belt basin western Montana: Canadian Journal of Earth Sciences, v. 35, p. 467475.

SEARS, J.W., AND PRICE, R.A., 2000, New look at the Siberian connection: No SWEAT: Geology, v. 28 , p. 423-426.

SeARS, J.W., and PrICE, R.A., 2003, Tightening the Siberian connection to western Laurentia: Geological Society of America, Bulletin, v. 115, p. 943-953.

SKIPP, B., 1987, Basement thrust sheets in the Clearwater orogenic zone, central Idaho and western Montana: Geology, v. 15, p. 220-224.

SKIPP, B., 1988, Cordilleran thrust belt and faulted foreland in the Beaverhead Mountains, Idaho and Montana, in Schmidt, C.J., and Perry, W.J., Jr., eds., Interaction of Rocky Mountain Foreland and Cordilleran Thrust Belt: Geological Society of America, Memoir 171, p. 237-266.

SKIPP, B., AND LINK, P.K., 1992. Middle and Late Proterozoic rocks and Later Proterozoic tectonics in the southern Beaverhead Mountains, Idaho and Montana: A preliminary report, in Link, P.K., Kuntz, M.A., and Platt, L.B., eds., Regional Geology of Eastern Idaho and Western Wyoming: Geological Society of America, Memoir 179, p. 141-154.

Tietвonl, D., 1986, Middle Proterozoic diamictite beds in the Lemhi Range, east-central Idaho, in Roberts, S.M., ed., Belt Supergroup: A Guide to Proterozoic Rocks of Western Montana and Adjacent Areas: Montana Bureau of Mines and Geology, Special Publication 94, p. 197-207.

TFra, F., AND WasserRurG, G., 1972, U-Th-Pb systematics in three Apollo 14 basalts and the problem of inittal $\mathrm{Pb}$ in lunar rocks: Earth and Planetary Science Letters, v. 14, p. 281-304.
TYSDAL, R.G., 2000a, Stratigraphy and sedimentology of Middle Proterozoic rocks in northern part of Lemhi Range, Lemhi County, Idaho: U.S. Geological Survey, Professional Paper 1600, 40 p.

TYSDAL, R.G., 2000b, Revision of Middle Proterozoic Yellowjacket Formation, central Idaho: U.S. Geological Survey, Professional Paper 1601A, p. A1-A13.

TYSDAL, R.G., 2002, Structural geology of western part of Lemhi Range, east-central Idaho: U.S. Geological Survey, Professional Paper 1659, $33 \mathrm{p}$.

TYSDAL, R.G., 2003, Correlation, sedimentology, and structural setting, upper strata of Mesoproterozoic Apple Creek Formation and lower strata of Gunsight Formation, Lemhi Range to Salmon River Mountains, east-central Idaho: U.S. Geological Survey, Professional Paper 1668-A, p. 1-22.

Tysdal, R.G., AND Desborough, G.A., 1997, Scapolitic metaevaporite and carbonate rocks of Proterozoic Yellowjacket Formation, Moyer Creek, Salmon River Mountains, central Idaho: U.S. Geological Survey, Open-File Report 97-268, $26 \mathrm{p}$

TYSDAL, R.G., LINDSEY, D.A., LuND, K.I., AND WINKLER, G.R., 2005, Alluvial facies, paleocurrents, and source of the Mesoproterozoic Gunsight Formation, east-central Idaho and southwestern Montana: U.S. Geological Survey, Professional Paper 1700-B, p. 16-39.

TYSDAL, R.G., LINDSEY, D.A., AND TAGGERT, J.E., JR., 2003, Correlation, sedimentology, structural setting, chemical composition, and provenance of selected formations in Mesoproterozoic Lemhi Group, central Idaho: U.S. Geological Survey, Professional Paper 1668, 40 p.

UMPLEBY, J.B., 1913, Geology and ore deposits of Lemhi County, Idaho: U.S. Geological Survey, Bulletin 528, 182 p.

VAIL, P.R., MrTCHUM, R.M., JR., AND THOMPSON, S., III, 1977, Seismic stratigraphy and global change of sea level. Part 4: Global cycles of relative changes of sea level, in Payton, C.E., ed., Seismic StratigraphyApplications to Hydrocarbon Exploration: American Association of Petroleum Geologists, Memoir 26, p. 83-97.

VERMEESCH, P., 2004, How many grains are needed for a provenance study?: Earth and Planetary Science Letters, v. 224, p. 441-451.

Williams, I.S., 1998, U-Th-Pb geochronology by ion microprobe, in McKibben, M.A., Shanks, W.C., III, and Ridley, W.E., eds., Applications of Microanalytical Techniques to Understanding Mineralizing Processes: Reviews in Economic Geology, v. 7, p. 1-35.

WINSTON, D., 1986, Sedimentation and tectonics of the Middle Proterozoic Belt basin, and their influence on Phanerozoic compression and extension in western Montana and northern Idaho, in Peterson, J.A., ed., Paleotectonics and Sedimentation in the Rocky Mountain Region, United States: American Association of Petroleum Geologists, Memoir 41, p. 87-118.

WINSTON, D., 2003, Proposed revision of the Helena and Wallace Formations, Mid-Proterozoic Belt Supergroup, Montana and Idaho: Northwest Geology, v. 32, p. 172-178.

Winston, D., AND LiNK, P.K., 1993, Middle Proterozoic rocks of Montana, Idaho, and Washington: The Belt Supergroup, in Reed, J., Bickford, M.E, Houston, R.S, Link, P.K., Rankin, R.W., Sims, P.K., and Van Schmus, W.R., eds., The Geological Society of America, The Geology of North America, Decade of North American Geology, Precambrian of the Conterminous United States, v. C-2, p. 487-521.

Winston, D., LINK, P.K., AND Hathawax, N., 1999, The Yellowjacket is not the Prichard and other heresies: Belt Supergroup correlations, structure and paleogeography, east-central Idaho, in Hughes, S.S., and Thackray, G.D., eds., Guidebook to the Geology of Eastern Idaho: Pocatello, Idaho, Museum of Natural History, p. 3-20.

Wust, S.L., 1986, Extensional deformation with northwest vergence, Pioneer core complex, central Idaho: Geology, v. 14, p. 712-714. 
TABLE 3A.-Summary of SHRIMP U-Pb zircon results for sample BB31.

\begin{tabular}{|c|c|c|c|c|c|c|c|c|c|c|c|c|c|c|c|c|c|c|c|c|c|}
\hline & & & & & & & & Total F & atios & & & Radiogenic & Ratios & & & & & & ge (Ma) & & \\
\hline Grain. & $\underline{U}$ & Th & Th/U & ${ }^{206} \mathrm{~Pb}^{*}$ & ${ }^{204} \mathrm{~Pb} /$ & $\mathbf{f}_{206}$ & ${ }^{238} \mathrm{U} / \mathrm{J}$ & & ${ }^{207} \mathrm{~Pb} /$ & & & ${ }^{207} \mathrm{~Pb}$ & & ${ }^{207} \mathrm{~Pb} /$ & & & ${ }^{20.6} \mathrm{~Pb} /$ & & ${ }^{207} \mathrm{~Pb} /$ & & $\%$ \\
\hline spot & (ppm) & (ppm) & & (ppm) & ${ }^{206} \mathrm{~Pb}$ & $\%$ & ${ }^{208} \mathrm{~Pb}$ & \pm & ${ }^{206} \mathrm{~Pb}$ & \pm & \pm & $235 \mathrm{U}$ & \pm & ${ }^{206} \mathrm{~Pb}$ & \pm & $\rho$ & ${ }^{238} \mathrm{U}$ & \pm & ${ }^{206} \mathrm{~Pb}$ & \pm & Disc \\
\hline & & & & & & & & & & & & & & & & & & & & & \\
\hline 1.1 & 2675 & 164 & 0.06 & 684.0 & 0.000367 & 0.59 & 3.360 & 0.035 & 0.1029 & 0.0002 & 0.0030 & 3.990 & 0.049 & 0.0979 & 0.0006 & 0.840 & 1670 & 15 & 1584 & 12 & -5 \\
\hline 2.1 & 390 & 189 & 0.49 & 100.4 & 0.000025 & 0.04 & 3.334 & 0.037 & 0.0994 & 0.0005 & 0.0033 & 4.095 & 0.051 & 0.0991 & 0.0006 & 0.893 & 1690 & 16 & 1606 & 10 & -5 \\
\hline 3.1 & 199 & 110 & 0.55 & 55.7 & 0.000011 & 0.02 & 3.077 & 0.036 & 0.1086 & 0.0007 & 0.0038 & 4.857 & 0.066 & 0.1084 & 0,0007 & 0.866 & 1814 & 19 & 1773 & 12 & -2 \\
\hline 4.1 & 480 & 58 & 0.12 & 133.1 & 0.000011 & 0.02 & 3.100 & 0.034 & 0.1096 & 0.0005 & 0.0035 & 4.866 & 0.058 & 0.1094 & 0.0005 & 0.925 & 1802 & 17 & 1790 & 8 & -1 \\
\hline 5.1 & 341 & 31 & 0.09 & 86.6 & 0.000025 & 0.04 & 3.383 & 0.045 & 0.0977 & 0.0005 & 0.0039 & 3.976 & 0.057 & 0.0976 & 0.0005 & 0.929 & 1669 & 20 & 1578 & 10 & -6 \\
\hline 6.1 & 177 & 244 & 1.38 & 45.4 & 0.000039 & 0.06 & 3.355 & 0.040 & 0.1022 & 0.0008 & 0.0036 & 4.174 & 0.061 & 0.1016 & 0.0008 & 0.827 & 1681 & 18 & 1654 & 15 & -2 \\
\hline 7.1 & 330 & 168 & 0.51 & 73.5 & 0.000094 & 0.15 & 3.859 & 0.042 & 0.0940 & 0.0005 & 0.0028 & 3.308 & 0.042 & 0.0927 & 0.0006 & 0.859 & 1483 & 15 & 1482 & 12 & 0 \\
\hline 8.1 & 179 & 53 & 0.30 & 43.0 & 0.000025 & 0.04 & 3.576 & 0.043 & 0.0972 & 0.0007 & 0.0033 & $\begin{array}{l}3.733 \\
\end{array}$ & 0.053 & 0.0969 & 0.0007 & 0.840 & 1589 & 17 & 1565 & 14 & -2 \\
\hline 9.1 & 114 & 72 & 0.63 & 29.4 & 0.000016 & 0.03 & 3.334 & 0.043 & 0.1008 & 0.0009 & 0.0039 & 4.160 & 0.065 & 0.1006 & 0.0009 & 0.829 & 1691 & 19 & 1636 & 16 & -3 \\
\hline 10.1 & 22 & 13 & 0.59 & 5.4 & 0.000293 & 0.47 & 3.465 & 0.066 & 0.1010 & 0,0018 & 0.0055 & 3.991 & 0.105 & 0.1004 & 0.0018 & 0.719 & 1633 & 30 & 1631 & 34 & 0 \\
\hline 11.1 & 546 & 88 & 0.16 & 143.9 & - & $<0,01$ & 3.258 & 0.035 & 0.1049 & 0.0004 & 0.0033 & 4.457 & 0.050 & 0.1053 & 0.0004 & 0.947 & 1726 & 16 & 1719 & 7 & 0 \\
\hline 12.1 & 179 & 88 & 0.49 & 43.7 & - & $<0.01$ & 3.520 & 0.043 & 0.0993 & 0.0007 & 0.0035 & 3.889 & 0.055 & \begin{tabular}{|l|l}
0.0993 \\
\end{tabular} & 0.0007 & 0.863 & 1612 & 18 & 1611 & 13 & 0 \\
\hline 13.1 & 187 & 189 & 1.01 & 51.3 & 0.000043 & \begin{tabular}{|l|} 
\\
\end{tabular} & 3.124 & 0.038 & 0.1076 & 0.0008 & 0.0039 & 4.718 & 0.067 & 0.1070 & 0.0008 & 0.855 & 1789 & 19 & 1749 & 13 & -2 \\
\hline 14.1 & 586 & 373 & 0.64 & 138.9 & 0.000029 & 0.05 & 3.624 & 0.054 & $\begin{array}{l}0.0992 \\
\end{array}$ & \begin{tabular}{ll|}
0.0006 \\
\end{tabular} & 0.0041 & 3.758 & 0.061 & 0.0988 & 0.0007 & $\begin{array}{l}0.911 \\
\end{array}$ & 1570 & 21 & 1602 & 13 & 2 \\
\hline 15.1 & 109 & 75 & 0.69 & 23.5 & 0.000134 & \begin{tabular}{|l|} 
\\
\end{tabular} & 3.971 & 0.094 & 0.0936 & 0.0008 & 0.0060 & 3.178 & 0.085 & 0.0917 & 0.0011 & 0.888 & 1445 & 31 & 1462 & 23 & 1 \\
\hline 16.1 & 345 & 319 & 0.92 & 83.4 & - & $<0.01$ & 3.554 & 0.039 & 0.0992 & 0.0005 & 0.0031 & 3.860 & 0.046 & 0.0995 & 0.0005 & 0.907 & 1599 & 15 & 1614 & 9 & 1 \\
\hline 17.1 & 193 & 133 & 0.69 & 59.5 & 0.000022 & 0.03 & 2.788 & 0.032 & 0.1205 & 0.0007 & 0.0041 & 5.941 & 0.076 & 0.1202 & 0.0007 & 0.899 & 1976 & 20 & 1959 & 10 & -1 \\
\hline 18.1 & 227 & 301 & 1.33 & 95.4 & 0.000013 & 0.02 & 2.045 & 0.024 & 0.1710 & 0.0008 & 0.0057 & 11.518 & 0.143 & 0.1709 & 0.0008 & 0.934 & 2566 & 25 & 2566 & 7 & 0 \\
\hline 19.1 & 343 & 271 & 0.79 & 80.5 & 0.000050 & 0.08 & 3.655 & 0.042 & 0.0989 & 0.0006 & 0.0031 & 3.702 & 0.049 & 0.0982 & 0.0006 & 0.874 & 1558 & 16 & 1590 & 12 & 2 \\
\hline 20.1 & 248 & 101 & 0.41 & 64.9 & 0.000010 & 0.02 & 3.281 & 0.039 & 0.1069 & 0.0011 & 0.0036 & 4.485 & 0.071 & $\begin{array}{l}0.1067 \\
\end{array}$ & 0.0011 & 0.745 & 1715 & 18 & 1744 & 19 & 2 \\
\hline 21.1 & 398 & 346 & 0.87 & 94.9 & 0.000043 & \begin{tabular}{l|l|}
0.07 \\
\end{tabular} & 3.600 & 0.044 & 0.0959 & 0.0006 & 0.0034 & $\begin{array}{l}3.646 \\
\end{array}$ & 0.051 & 0.0953 & 0.0006 & 0.874 & 1579. & 17 & 1534 & 13 & -3 \\
\hline 22.1 & 103 & 66 & 0.64 & 25.8 & 0.000139 & 0.22 & 3.425 & 0.049 & 0.1080 & 0.0012 & 0.0042 & 4.263 & 0.083 & 0.1061 & 0.0014 & 0.743 & 1648 & 21 & 1734 & 24 & 5 \\
\hline 23.1 & 235 & 116 & 0.49 & 63.2 & 0.000031 & 0.05 & 3.197 & 0.038 & 0.1107 & 0.0007 & 0.0037 & $\begin{array}{l}4.754 \\
\end{array}$ & 0.064 & 0.1103 & 0.0007 & 0.872 & 1753 & 18 & 1804 & 12 & 3 \\
\hline 24.1 & 292 & 72 & 0.25 & 80.5 & 0.000097 & 0.15 & 3.118 & 0.036 & 0.1098 & 0.0006 & 0.0037 & 4.789 & 0.065 & 0.1085 & 0.0008 & 0.836 & 1791 & 18 & 1774 & 14 & -1 \\
\hline 25.1 & 289 & 262 & 0.91 & \begin{tabular}{l|l|}
62.5 \\
\end{tabular} & 0.000214 & 0.35 & 3.980 & 0.046 & 0.0957 & 0.0006 & 0.0029 & 3.200 & 0.049 & 0.0927 & 0.0010 & 0.745 & 1441 & 15 & 1481 & 19 & 3 \\
\hline 26.1 & 192 & 129 & 0.67 & 52.5 & - & $<0.01$ & 3.142 & 0.043 & 0.1098 & 0.0009 & 0.0043 & 4.819 & 0.077 & 0.1098 & 0.0009 & 0.847 & 1781 & 21 & 1796 & 16 & 1 \\
\hline 27.1 & 154 & 207 & 1.34 & 39 & 0.000004 & 0.01 & 3.440 & 0.041 & 0.1008 & 0.0007 & 0.0035 & 4.038 & 0.056 & 0.1008 & 0.0007 & 0.867 & 1645 & 17 & 1638 & 13 & 0 \\
\hline 28.1 & 485 & 138 & 0.28 & 119 & - & $<0.01$ & 3.502 & 0.039 & 0.0978 & 0.0004 & 0.0032 & 3.851 & 0.046 & 0.0978 & 0.0004 & 0.937 & 1619 & 16 & 1583 & 8 & -2 \\
\hline 29.1 & 176 & 56 & 0.32 & 43.2 & 0.001040 & 1.69 & 3.507 & 0.042 & 0.1048 & 0.0010 & 0.0034 & 3.809 & 0.069 & $\begin{array}{l}0.0977 \\
\end{array}$ & 0.0013 & 0.664 & 1605 & 18 & 1581 & 25 & -1 \\
\hline 30.1 & 140 & 134 & 0.96 & 33.2 & - & $<0.01$ & 3.618 & 0.045 & 0.0991 & 0.0009 & $\mathbf{0 . 0 0 3 5}$ & 3.796 & 0.057 & 0.0996 & 0.0009 & 0.824 & 1574 & 17 & 1616 & 16 & 3 \\
\hline 31.1 & 249 & 163 & 0.65 & 66.5 & 0.000018 & 0.03 & 3.217 & $\begin{array}{l}0.037 \\
\end{array}$ & $\begin{array}{l}0.1067 \\
\end{array}$ & 0.0007 & 0.0036 & 4.559 & 0.060 & 0.1064 & 0.0007 & 0.873 & 1744 & 18 & 1739 & 12 & 0 \\
\hline 32.1 & 84 & 65 & 0.78 & 21.2 & 0.000113 & 0.18 & 3.403 & 0.048 & $\begin{array}{l}0.1003 \\
\end{array}$ & 0.0011 & 0.0041 & 4.131 & 0.075 & 0.1018 & 0.0012 & 0.778 & 1663 & 23 & 1657 & 21 & 0 \\
\hline 33.1 & 216 & 301 & 1.40 & 55 & 0.000012 & 0.02 & 3.384 & 0.039 & 0.0994 & 0.0006 & 0.0034 & 4.045 & 0.053 & 0.0993 & 0.0006 & 0.887 & 1669 & 17 & 1611 & 11 & -4 \\
\hline 34.1 & 484 & 73 & 0.15 & 124.8 & - & $<0.01$ & 3.332 & $\begin{array}{l}0.036 \\
\end{array}$ & 0.1076 & 0.0005 & 0.0033 & 4.456 & 0.054 & 0.1077 & 0.0005 & 0.907 & 1692 & 16 & 1761 & 9 & 4 \\
\hline 35.1 & 257 & 117 & 0.45 & 60.0 & 0.000037 & 0.06 & 3.682 & 0.042 & 0.0999 & 0.0006 & 0.0031 & 3.721 & 0.050 & 0.0994 & 0.0007 & 0.853 & 1548 & 16 & 1613 & 13 & 4 \\
\hline 36.1 & 546 & 341 & 0.63 & 123.2 & 0,000012 & 0.02 & \begin{tabular}{|l|l|}
3.810 \\
\end{tabular} & 0.069 & 0.0963 & 0.0005 & 0.0048 & 3.480 & \begin{tabular}{|l|}
0.066 \\
\end{tabular} & 0.0962 & 0.0005 & 0.960 & 1502 & 24 & 1551 & 10 & 3 \\
\hline 37.1 & 522 & 226 & 0.43 & 136.2 & 0.000015 & 0.02 & 3.290 & 0.036 & 0.1070 & 0.0005 & 0.0033 & 4.473 & 0.053 & 0.1068 & 0.0005 & 0.917 & 1711 & 16 & 1745 & 9 & 2 \\
\hline 38.1 & 84 & 51 & 0.61 & 20.6 & 0.000087 & $\begin{array}{l}0.14 \\
\end{array}$ & $\begin{array}{l}3.498 \\
\end{array}$ & 0.049 & 0.1004 & 0.0011 & 0.0040 & 3.904 & 0.074 & 0.0992 & 0.0013 & 0.736 & 1619 & 20 & 1609 & 24 & -1 \\
\hline 39.1 & 231 & 133 & 0.58 & 59.3 & 0.000018 & $\begin{array}{l}0.03 \\
\end{array}$ & 3.350 & 0.045 & \begin{tabular}{|l|l}
0.1089 \\
\end{tabular} & 0.0008 & 0.0040 & 4.471 & 0.068 & 0.1087 & 0.0008 & 0.883 & 1684 & 20 & 7777 & 13 & 5 \\
\hline 40.1 & 192. & \begin{tabular}{|l|}
140 \\
\end{tabular} & 0.73 & 44.1 & 0.000056 & 0.09 & 3.744 & 0.048 & 0.0955 & 0.0010 & 0.0034 & 3.485 & 0.060 & 0.0947 & 0.0011 & 0.738 & 1525 & 17 & 1522 & 22 & 0 \\
\hline 41.1 & 450 & 49 & 0.11 & 109.6 & 0.000023 & 0.04 & 3.531 & 0.039 & 0.1001 & 0.0005 & 0.0031 & 3.895 & 0.047 & 0.0998 & 0.0005 & 0.905 & 1607 & 16 & 1620 & 10 & 1 \\
\hline 42.1 & 86 & 157 & 1.84 & 20.3 & 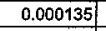 & 0.22 & 3.621 & 0.053 & 0.1015 & 0.0013 & 0.0040 & 3.787 & $\begin{array}{l}0.076 \\
\end{array}$ & 0.0996 & 0.0014 & 0.729 & 1569 & 20 & 1618 & 26 & 3 \\
\hline 43.1 & 198 & 214 & 1.08 & \begin{tabular}{|l|}
45.9 \\
\end{tabular} & 0.000066 & 0.11 & 3.708 & 0.045 & 0.0959 & \begin{tabular}{l|l}
0.0008 \\
\end{tabular} & 0.0033 & 3.576 & 0.052 & \begin{tabular}{|l|}
0.0962 \\
\end{tabular} & 0.0008 & 0.834 & 1540 & 20 & 1551 & 15 & 1 \\
\hline 44.1 & 186 & 95 & 0.51 & 44.7 & 0.000261 & 0.42 & 3.567 & 0.045 & 0.1010 & 0.0008 & 0.0035 & 3.766 & 0.058 & 0.0978 & 0.0009 & 0.818 & 1588 & 19 & 1583 & 17 & 0 \\
\hline 45.1 & 129 & 97 & $\begin{array}{l}0.75 \\
\end{array}$ & 31.1 & 0.000070 & 0.11 & 3.558 & 0.047 & \begin{tabular}{l|l|}
0.0996 \\
\end{tabular} & 0.0009 & 0.0037 & 3.818 & 0.065 & 0.0986 & 0.0011 & 0.771 & 1595 & 19 & 1599 & 20 & 0 \\
\hline 46.1 & 335 & 80 & 0.24 & 87.4 & 0.000014 & 0.02 & 3.297 & 0.038 & $\begin{array}{ll}0.1067 \\
\end{array}$ & 0.0006 & 0.0035 & 4.455 & 0.058 & 0.1066 & 0.0006 & 0.894 & 1707 & 17 & 1741 & 11 & 4 \\
\hline 47.1 & 456 & 359 & 0.79 & 119.2 & 0,000070 & 0.11 & 3.286 & 0.038 & 0.1011 & 0.0005 & 0.0035 & 4.849 & 0.089 & 0.1138 & 0.0016 & 0.621 & 1736 & 19 & 1861 & 26 & 7 \\
\hline 48.1 & 716 & 535 & 0.75 & 169.1 & 0.000025 & 0.04 & 3.637 & 0.039 & 0.0955 & 0.0004 & 0.0029 & 3.640 & 0.041 & 0.0959 & 0.0004 & 0.939 & 1567 & 16 & 1547 & 7 & -1 \\
\hline 49.1 & 374 & 50 & 0.13 & 90.0 & 0.000019 & 0.03 & 3.574 & 0.040 & 0.0982 & 0.0005 & 0.0031 & 3.777 & 0.047 & 0.0979 & 0.0006 & 0.891 & 1590 & 16 . & 1585 & 11 & 0 \\
\hline 50.1 & 39 & 45 & 1.16 & 9.4 & - & $<0.01$ & 3.571 & 0.060 & 0.1020 & 0.0022 & 0.0047 & 3.986 & 0.109 & 0.1031 & 0.0022 & 0.614 & 1593 & 24 & 1681 & 40 & 5 \\
\hline 51.1 & 69 & 60 & 0.86 & $\begin{array}{l}17.3 \\
\end{array}$ & - & $<0.01$ & 3.431 & 0.049 & 0.7004 & 0.0012 & 0.0042 & 4.035 & 0.075 & $\begin{array}{l}0.1004 \\
\end{array}$ & 0.0012 & 0.774 & 1649 & 21 & 1631 & 22 & -1 \\
\hline 52.1 & 571 & 98 & 0.17 & 129.6 & 0.000008 & 0.01 & 3.787 & 0.041 & 0.0960 & 0.0004 & 0.0028 & 3.490 & 0.040 & 0.0959 & 0.0004 & 0.927 & 1510 & 14 & 1545 & 8 & 2 \\
\hline 53.1 & 772 & 152 & 0.20 & 233.3 & - & $<0.01$ & 2,842 & 0.030 & 0.1178 & 0.0004 & 0.0037 & 5.720 & 0.063 & 0.1179 & 0.0004 & 0.957 & 1944 & 18 & 1924 & 6 & -1 \\
\hline 54.1 & 135 & 63 & 0.47 & 38.1 & 0.000033 & 0.05 & 3.040 & 0.037 & 0.1092 & 0.0008 & 0.0040 & 4.932 & 0.072 & 0.1088 & 0.0008 & 0.847 & 1832 & 20 & 1779 & 14 & -3 \\
\hline 55.1 & 188 & 121 & $\begin{array}{ll}0.64 \\
\end{array}$ & 43.2 & 0.000047 & 0.08 & 3.736 & 0.045 & 0.0954 & 0.0008 & 0.0033 & 3.493 & 0.051 & 0.0947 & 0.0008 & 0.827 & 1528 & 17 & 1522 & 16 & 0 \\
\hline 56.1 & 121 & 54 & 0.45 & 30.0 & 0.000155 & 0.25 & 3.466 & 0.045 & 0.1003 & 0.0009 & 0.0037 & 3.969 & 0.063 & $\begin{array}{l}0.0998 \\
\end{array}$ & 0.0009 & 0.809 & 1633 & 20 & 1621 & 17 & -1 \\
\hline 57.1 & 87 & 74 & 0.85 & 21.8 & 0.003618 & 5.86 & 3.429 & 0.049 & 0.1427 & 0.0018 & 0.0040 & 4.362 & 0.177 & 0.1127 & 0.0043 & \begin{tabular}{l|l|}
0.349 \\
\end{tabular} & 1595 & 25 & $\begin{array}{l}1843 \\
\end{array}$ & 69 & 13 \\
\hline 58.1 & 163 & 131 & 0.80 & 39.6 & 0.000046 & 0.07 & 3.535 & 0.044 & 0.1009 & 0.0008 & 0.0035 & 3.906 & 0.059 & 0.1002 & 0.0008 & 0.827 & 1605 & 18 & 1628 & 16 & 1 \\
\hline 59.1 & 106 & 69 & 0.65 & 26.1 & 0.000372 & 0.60 & 3.506 & 0.048 & 0.1001 & 0.0010 & 0.0039 & 3.878 & 0.067 & 0.0988 & 0.0011 & 0.787 & 1615 & 21 & 1601 & 20 & -1 \\
\hline 60.1 & 74 & 37 & 0.50 & 18.1 & 0.000099 & 0.16 & 3.506 & 0.051 & 0.0990 & 0.0012 & 0.0041 & 3.935 & 0.074 & 0.1000 & 0.0012 & 0.774 & 1619 & 22 & 1623 & 22 & 0 \\
\hline 61.1 & 160 & 121 & 0.76 & 38.9 & 0.000028 & 0.04 & 3.534 & 0.044 & 0.0988 & 0.0008 & 0.0035 & 3.838 & 0.058 & 0.0984 & 0.0008 & 0.826 & 1606 & 18 & 1594 & 16 & -1 \\
\hline 62.1 & 436 & 193. & 0.44 & 104.8 & - & $<0.01$ & 3.578 & 0.040 & 0.0999 & 0.0005 & 0.0031 & 3.851 & 0.047 & 0.0999 & 0.0005 & 0.912 & 1589 & 16 & 1623 & $\theta$ & 2 \\
\hline 63.1 & 290 & 76 & 0.26 & 79.2 & 0.000038 & 0.06 & 3.144 & 0.036 & 0.1100 & 0.0006 & 0.0036 & 4.800 & 0.061 & 0.1095 & 0.0006 & 0.891 & 1779 & 18 & 1792 & 11 & \\
\hline & & & & & & & & & & & & & & & & & & & & & \\
\hline & & & & & & & & & & & & & & & & & & & & & \\
\hline Notes & & 1. Unc & irtainties & s given at & one o level. & & & & & & & & & & & & & & & & \\
\hline & & 2. Error & $\pi$ & Eren & (1) & $\mathrm{n}^{2}$ & $8 \%$ & & & & & & & & & & & & & & \\
\hline & & & (not in & (I) & riors b & & then & & & in diffe & it mounts). & & & & & & & & & & \\
\hline & & 3. $\frac{1}{2039}$ & denote & es the per & ntage of ${ }^{200 \mathrm{pb}}$ & b that is & common & & & & & & & & & & & & & & \\
\hline & & 4. For & areas old & der than - & 0 Ma correct & tion for & ommon $\mathrm{P}$ & $b$ made & tg the $m$ & $\mathrm{ed}^{20 \mathrm{Ppb}}$ & Pb ratio. & & & & & & & & & & \\
\hline & & 5. For & areas you & unger tha & $1 \sim 800 \mathrm{Ma}$ corr & rection $t$ & or commo & $\mathrm{nPb}$ mad & using the & sured ${ }^{230} \mathrm{U}$ & ${ }^{200} \mathrm{~Pb}$ and & 10010 & os & & & & & & & & \\
\hline & & & following & Tera and & Wasserburg ( & 1972) as & outlined i & in Williams & (1998). & & & & & & & & & & & & \\
\hline & & 6. For & $\%$ Disc, 0 & $0 \%$ denot & s a concordan & tanalys & & & & & & & & & & & & & & & \\
\hline
\end{tabular}


TABLE 3B.-Summary of SHRIMP U-Pb zircon results for sample 13PL01.

\begin{tabular}{|c|c|c|c|c|c|c|c|c|c|c|c|c|c|c|c|c|c|c|c|c|}
\hline & & & & & & & & Total R & atios & & & & Radiogenic & Ratios & & & & & & (10) \\
\hline Grain. & U & Th & ThN & $\mathbf{P b}^{\mathbf{*}}$ & ${ }^{204} \mathrm{~Pb} /$ & $f_{206}$ & ${ }^{238} \mathrm{U} /$ & & ${ }^{207} \mathrm{~Pb} /$ & & ${ }^{206} \mathrm{~Pb} /$ & & ${ }^{209} \mathrm{~Pb} /$ & & ${ }^{207} \mathrm{~Pb} /$ & & & ${ }^{206} \mathrm{~Pb} /$ & & ${ }^{200} \mathrm{~Pb} /$ \\
\hline spot & (ppm) & (ppm) & & $(\mathrm{ppm})$ & ${ }^{200} \mathrm{~Pb}$ & $\%$ & ${ }^{200} \mathrm{~Pb}$ & \pm & ${ }^{200} \mathrm{~Pb}$ & \pm & ${ }^{238} \mathrm{U}$ & \pm & ${ }^{235} \mathrm{U}$ & \pm & ${ }^{206} \mathrm{~Pb}$ & \pm & $\rho$ & ${ }^{238} \mathrm{U}$ & \pm & ${ }^{206} \mathrm{~Pb}$ \\
\hline & & & & & & & & & & & & & & & & & & & & \\
\hline 1.1 & 556 & 56 & 0.10 & \begin{tabular}{|l|}
147 \\
\end{tabular} & 0.000011 & 0.02 & 3.240 & 0.036 & 0.1048 & 0.0004 & \begin{tabular}{|c|}
0.3086 \\
\end{tabular} & 0.0035 & 4.455 & 0.054 & \begin{tabular}{|l|l|}
0.1047 \\
\end{tabular} & 0.0005 & 0.932 & 1734 & 17 & 1709 \\
\hline 2.1 & 157 & 161 & 1.03 & 33 & 0.000052 & 0.08 & 4.047 & 0.049 & 0.0924 & 0.0008 & $\begin{array}{ll}0.2469 \\
\end{array}$ & 0.0030 & 3.121 & 0.046 & 0.0917 & |0.0008 & 0.810 & 1422 & 15 & 1467 \\
\hline 2.1 & 218 & 242 & 1.11 & 47 & 0.000043 & 0.07 & 3.957 & 0.064 & 0.0923 & 0.0007 & 0.2526 & 0.0041 & 3.194 & 0.058 & 0.0917 & 0.0008 & 0.890 & 1452 & 21 & 1462 \\
\hline 3.1 & 364 & 190 & 0.52 & 92 & 0.000016 & 0.03 & 3.408 & 0.038 & 0.1047 & 0.0006 & 0.2934 & 0.0032 & 4.224 & 0.053 & 0.1044 & 0.0006 & 0.872 & 1658 & 16 & 1704 \\
\hline 4.1 & 341 & 95 & 0.28 & 83 & 0.000006 & 0.01 & 3.534 & 0.040 & 0.1054 & 0.0005 & 0.2829 & 0.0032 & 4.111 & 0.051 & 0.1054 & 0.0005 & 0.919 & 1606 & 16 & 1721 \\
\hline 5.1 & 1573 & 630 & 0.40 & 396 & 0,000008 & 0.01 & 3.408 & 0.036 & 0.1029 & 0.0002 & 0.2934 & 0.0031 & 4.157 & 0.045 & 0.1028 & 0.0003 & 0.974 & 1659 & 15 & 1675 \\
\hline 6.1 & 372 & 109 & 0.29 & 94 & 0.000001 & 0.00 & 3.397 & 0.039 & 0.1044 & 0.0005 & 0.2944 & 0.0034 & 4.238 & 0.053 & 0.1044 & 0.0005 & 0.917 & 1663 & 17 & 1704 \\
\hline 7.1 & 284 & 179 & 0.63 & 61 & 0.000025 & 0.04 & 4.031 & 0.045 & 0.0917 & 0.0006 & 0.2480 & 0.0028 & \begin{tabular}{|l|l|}
3.123 \\
\end{tabular} & 0.041 & 0.0913 & 0.0006 & 0.859 & 1428 & 14 & 1454 \\
\hline 7.1 & 380 & 233 & 0.61 & 80 & 0.000018 & 0.03 & 4.068 & 0.046 & 0.0919 & 0.0006 & \begin{tabular}{l|l|}
0.2457 \\
\end{tabular} & 0.0028 & 3.106 & 0.040 & 0.0917 & 0.0006 & 0.874 & 1416 & 14 & 1461 \\
\hline 7.2 & 9355 & 257 & 0.19 & 229 & 0.000021 & 0.03 & 5.085 & \begin{tabular}{l|l}
0.055 \\
\end{tabular} & 0.0978 & 0.0003 & 0.1966 & 0.0021 & 2.644 & 0.030 & 0.0975 & 0.0003 & 0.955 & 1157 & 11 & 1577 \\
\hline 8.1 & 984 & 147 & 0.15 & 279 & - & $<0.01$ & \begin{tabular}{l|l}
3.025 \\
\end{tabular} & 0.047 & 0.1060 & 0.0017 & 0.3306 & 0.0051 & 4.837 & 0.107 & 0.1061 & 0.0017 & 0.697 & 1841 & 25 & \begin{tabular}{|l|l|}
1734 \\
\end{tabular} \\
\hline 9.1 & 406 & 13 & 0.03 & 110 & - & $<0.01$ & 3.170 & 0.035 & 0.1042 & 0.0004 & 0.3154 & 0.0034 & 4.533 & 0.053 & 0.1042 & 0.0004 & 0.930 & 1767 & 17 & 1700 \\
\hline 10.1 & 271 & 47 & $\begin{array}{l}0.17 \\
\end{array}$ & 71 & 0.000008 & 0.01 & \begin{tabular}{|l|l|}
3,268 \\
\end{tabular} & 0.053 & 0.1061 & 0.0006 & 0.3059 & 0.0050 & 4.473 & 0.076 & 0.1060 & 0.0006 & 0.948 & 1721 & 24 & 1732 \\
\hline 11.1 & 666 & 228 & 0.34 & 191 & 0.000007 & 0.01 & 3.000 & $\begin{array}{l}0.032 \\
\end{array}$ & 0.1060 & 0.0004 & \begin{tabular}{l|}
0.3333 \\
\end{tabular} & 0.0036 & 4.869 & 0.056 & 0.1059 & 0.0004 & 0.941 & 1855 & $\begin{array}{l}17 \\
\end{array}$ & 1731 \\
\hline 12.1 & 180 & 95 & 0.53 & 48 & 0.000005 & 0.01 & \begin{tabular}{l|l}
3.2466 \\
\end{tabular} & \begin{tabular}{l|}
0.037 \\
\end{tabular} & 0.1051 & 0.0007 & 0.3080 & 0.0036 & 4.462 & 0.059 & 0.1051 & 0.0007 & 0.865 & 1731 & 17 & $17+5$ \\
\hline 13.1 & 198 & 92 & 0.46 & 51 & 0.000053 & 0.08 & 3.327 & 0.041 & 0.1044 & 0.0008 & 0.3003 & 0.0037 & 4.292 & 0.063 & 0.1036 & 0.0008 & \begin{tabular}{|l||}
0.842 \\
\end{tabular} & 1693 & 18 & 1690 \\
\hline 14.1 & 228 & 54 & 0.24 & 61 & 0.000032 & 0.05 & 3.208 & 0.036 & 0.1035 & 0.0006 & 0.3115 & 0.0035 & 4.426 & 0.056 & 0.1030 & 0.0006 & 0.893 & 1748 & 17 & 1680 \\
\hline 15.1 & 3007 & 180 & 0.18 & 251 & 0.000003 & 0.01 & 3.444 & 0.036 & 0.1023 & 0.0003 & 0.2904 & 0.0031 & 4.092 & 0.045 & 0.1022 & 0.0003 & 0.961 & 1643 & 15 & 1665 \\
\hline 96.1 & 677 & 283 & 0.42 & $\begin{array}{ll}166 \\
\end{array}$ & 0.000017 & 0.03 & 3.509 & 0.038 & 0.1037 & 0.0004 & 0.2849 & 0.0030 & 4.064 & 0.046 & 0.1034 & 0.0004 & 0.947 & 1616 & 15 & 1687 \\
\hline 17.1 & 283 & 66 & 0.23 & 78 & 0.000002 & $<0.01$ & \begin{tabular}{|l|}
3.103 \\
\end{tabular} & $\begin{array}{ll}0.035 \\
\end{array}$ & 0.1050 & 0.0006 & \begin{tabular}{l|l}
0.3223 \\
\end{tabular} & 0.0037 & 4.662 & 0.060 & 0.1049 & 0.0006 & 0.881 & 1801 & 18 & 1713 \\
\hline 18.1 & 123 & 36 & 0.29 & 35 & - & \begin{tabular}{|c|c|} 
\\
\end{tabular} & 2.985 & 0.038 & 0.1055 & 0.0008 & 0.3351 & 0.0043 & 4.887 & 0.073 & 0.1058 & 0.0008 & 0.861 & 1863 & 21 & 1727 \\
\hline 19.1 & 414 & 62 & 0.15 & 109 & - & $<0.01$ & \begin{tabular}{ll|}
3.256 \\
\end{tabular} & \begin{tabular}{ll|}
0.036 \\
\end{tabular} & 0.1052 & 0.0005 & 0.3072 & 0.0034 & 4.462 & 0.054 & 0.1054 & 0.0005 & 0.909 & 1727 & 17 & 1721 \\
\hline 20.1 & 190 & 105 & 0.55 & 45 & 0.000026 & 0.04 & 3.608 & 0.044 & 0.1027 & 0.0008 & 0.2770 & 0.0034 & 3.910 & 0.056 & 0.1024 & 0.0008 & 0.844 & 9576 & 17 & 1668 \\
\hline 21.1 & 334 & 142 & 0.42 & 69 & 0.000018 & 0.03 & 4.158 & 0.062 & 0.0993 & 0.0007 & 0.2404 & 0.0036 & 3.283 & 0.054 & 0.0990 & 0.0007 & 0.906 & 1389 & 19 & 1606 \\
\hline 22.1 & 405 & 100 & 0.25 & 76 & 0.000018 & 0.03 & 4.566 & 0.051 & 0.0970 & 0.0005 & 0.2190 & 0.0025 & 2.920 & 0.037 & 0.0967 & 0.0006 & \begin{tabular}{l|l}
0.879 \\
\end{tabular} & 1276 & 13 & 1562 \\
\hline 23.1 & 277 & 115 & 0.42 & 71 & & $<0.01$ & 3.364 & 0.038 & 0.1042 & 0.0006 & 0.2974 & 0.0033 & 4.279 & 0.054 & 0.1044 & 0.0006 & 0.883 & 1678 & 17 & 1703 \\
\hline 24.1 & 357 & 108 & 0.30 & 82 & 0.000027 & 0.04 & \begin{tabular}{|l|l|}
3.738 \\
\end{tabular} & 0.041 & 0.1019 & 0.0005 & 0.2674 & 0.0029 & 3.743 & 0.045 & 0.1015 & 0.0005 & 0.904 & 1527 & 15 & 1652 \\
\hline 25.1 & 449 & 120 & 0.27 & 115 & 0.000061 & 0.10 & 3.362 & 0.037 & $\begin{array}{l}0.1057 \\
\end{array}$ & 0.0004 & 0.2971 & 0.0032 & 4.298 & 0.052 & $\begin{array}{ll}0.1049 \\
\end{array}$ & 0.0005 & 0.903 & 1677 & 16 & 1713 \\
\hline 26.1 & 352 & 145 & 0.41 & 79 & - & $<0.01$ & 3.841 & 0.043 & 0.1060 & 0.0006 & 0.2604 & 0.0029 & 3.808 & 0.049 & 0.1061 & 0.0006 & 0.885 & 1492 & 15 & 1733 \\
\hline 27.1 & 642 & 32 & 0.05 & 171 & 0.000009 & 0.01 & 3.235 & 0.035 & 0.1036 & 0.0004 & 0.3091 & 0.0033 & 4.409 & 0.050 & 0.1034 & 0.0004 & 0.946 & 1736 & 16 & 1687 \\
\hline 28.1 & 221 & 102 & 0.46 & 90 & 0.000024 & 0.03 & 2.109 & 0.024 & 0.1593 & 0.0008 & 0.4739 & 0.0054 & 10.390 & 0.130 & 0.1590 & 0.0008 & 0.908 & 2501 & 24 & 2445 \\
\hline 29.1 & 1316 & 160 & 0.12 & 287 & 0.000005 & 0.01 & $\begin{array}{l}3.935 \\
\end{array}$ & 0.045 & 0.0913 & 0.0003 & 0.2541 & 0.0029 & 3.195 & 0.038 & 0.0912 & 0.0003 & \begin{tabular}{|c||}
0.961 \\
\end{tabular} & 1460 & 15 & 1450 \\
\hline 30.1 & 284 & 58 & 0.20 & 79 & 0.000011 & 0.02 & 3.084 & 0.035 & 0.1093 & 0.0006 & 0.3242 & 0.0037 & 4.877 & 0.061 & 0.1091 & 0.0006 & 0.901 & 1810 & 18 & 1784 \\
\hline 31.1 & 393. & 124 & 0.32 & $106:$ & 0.000013 & 0.02 & 3.192 & 0.035 & 0.1099 & 0.0005 & 0.3132 & 0.0034 & 4.736 & 0.056 & 0.1097 & 0.0005 & 0.924 & 1756 & \begin{tabular}{l|l|}
17 \\
\end{tabular} & 1794 \\
\hline 32.1 & 846 & 42 & 0.05 & 225 & - & $<0.01$ & 3.233 & 0.035 & 0.1060 & 0.0006 & 0.3093 & 0.0033 & 4.524 & 0.054 & 0.1061 & 0.0006 & 0.899 & 1737 & 16 & 1733 \\
\hline 33.1 & 146 & 64 & $\begin{array}{ll}0.44 \\
\end{array}$ & 30 & 0.000110 & 0.17 & 4.199 & $\begin{array}{l}0.053 \\
\end{array}$ & 0.1025 & 0.0008 & 0.2378 & 0.0030 & 3.312 & 0.052 & 0.1010 & 0.0009 & 0.807 & 1375 & 16 & 1643 \\
\hline 34.1 & 222 & 30 & 0.14 & 51 & - & $<0.01$ & 3.762 & 0.043 & \begin{tabular}{|l|l|}
0.1086 \\
\end{tabular} & 0.0007 & 0.2659 & 0.0031 & 3.985 & 0.052 & 0.1087 & 0.0007 & 0.877 & 1520 & 16 & 1778 \\
\hline 36.1 & 132 & 88 & 0.66 & 29 & - & $<0.01$ & 3.886 & 0.047 & 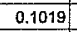 & 0.0010 & 0.2573 & 0.0031 & 3.617 & 0.056 & \begin{tabular}{|l|l|}
0.1019 \\
\end{tabular} & 0.0010 & 0.780 & 1476 & 16 & 1660 \\
\hline 37.1 & 996 & 371 & 0.37 & 273 & 0.000004 & 0.01 & \begin{tabular}{ll|}
3.128 \\
\end{tabular} & 0.033 & $\begin{array}{l}0.1103 \\
\end{array}$ & 0.0003 & 0.3196 & 0.0034 & 4.858 & 0.053 & 0.1102 & 0.0003 & 0.970 & 1788 & 16 & 1803 \\
\hline 38.1 & 359 & 247 & $\begin{array}{ll}0.69 \\
\end{array}$ & 94 & 0.000019 & 0.03 & 3.272 & 0.038 & \begin{tabular}{l|l}
0.1055 \\
\end{tabular} & 0,0004 & 0.3055 & 0.0035 & 4.433 & 0.055 & 0.1052 & 0.0005 & 0.936 & 1749 & 17 & 1719 \\
\hline 39.1 & 72 & 29 & 0.40 & 18 & 0.000037 & 0.06 & 3.347 & $\begin{array}{ll}0.044 \\
\end{array}$ & 0.1074 & 0.0010 & 0.2986 & 0.0039 & 4.399 & 0.073 & 0.1069 & 0.0011 & \begin{tabular}{|l|}
0.793 \\
\end{tabular} & 1684 & 20 & $\begin{array}{l}1747 \\
\end{array}$ \\
\hline 40.1 & 970 & 133 & $\begin{array}{ll}0.14 \\
\end{array}$ & 263 & 0.000002 & $<0.01$ & 3.174 & \begin{tabular}{|c|}
0.034 \\
\end{tabular} & 0.1050 & 0.0004 & 0.3150 & 0.0034 & 4.559 & 0.051 & 0.1050 & 0.0004 & 0.949 & 1765 & 16 & 1714 \\
\hline 41.1 & 115 & 76 & 0.66 & 32 & 0.000123 & \begin{tabular}{|l|l}
0.19 \\
\end{tabular} & \begin{tabular}{l|l}
3.067 \\
\end{tabular} & 0.038 & 0.1054 & 0.0009 & 0.3254 & 0.0040 & 4.654 & 0.075 & 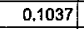 & 0.0011 & 0.776 & 1816 & 20 & 1692 \\
\hline 42.1 & 807 & 55 & 0.07 & 185 & 0.000007 & 0.01 & 3.740 & $\begin{array}{ll}0.042 \\
\end{array}$ & 0.1033 & 0.0003 & 0.2673 & 0.0030 & 3.802 & 0.044 & 0.1032 & 0.0004 & 0.956 & 1527. & 15 & 1682 \\
\hline 43.1 & 146 & \begin{tabular}{|l|l}
53 \\
\end{tabular} & $\begin{array}{l}0.36 \\
0\end{array}$ & 56 & 0.000002 & $<0.01$ & 2.230 & 0.028 & 0.1602 & 0.0008 & 0.4485 & 0.0056 & 9.905 & 0.133 & 0.1602 & 0.0009 & 0.919 & 2389 & 25 & 2458 \\
\hline 44.1 & 399 & $64 \mid$ & 0.16 & 98 & 0.000017 & $\begin{array}{ll}0.03 \\
\end{array}$ & \begin{tabular}{ll|}
3.502 \\
\end{tabular} & 0.040 & 0.1020 & 0.0005 & 0.2855 & 0.0033 & 4.006 & \begin{tabular}{|l|l|}
0.050 \\
\end{tabular} & 0.1018 & 0.0005 & 0.918 & 1619 & 16 & 1657 \\
\hline 45.1 & 1091 & 176 & 0.16 & 279 & - & \begin{tabular}{|c|c|} 
\\
\end{tabular} & \begin{tabular}{l|l}
3.362 \\
\end{tabular} & \begin{tabular}{|l|l|}
0.037 \\
\end{tabular} & 0.1024 & 0.0003 & 0.2975 & 0.0033 & 4.207 & 0.048 & 0.1026 & 0.0003 & 0.965 & 1679 & 16 & 1671 \\
\hline 46.1 & 201 & 70 & $\begin{array}{ll}0.35 \\
\end{array}$ & 46 & 0.000034 & 0.05 & 3.751 & $\begin{array}{l}0.046 \\
\end{array}$ & 0.1009 & 0.0008 & 0.2665 & 0.0033 & 3.691 & 0.054 & 0.1004 & 0.0008 & 0.835 & 1523 & 17 & 1632 \\
\hline 47.1 & 530 & 344 & 0.65 & 123 & 0.000004 & 0.01 & 3.712 & 0.044 & 0.1073 & 0.0005 & $\begin{array}{ll}0.2694 \\
\end{array}$ & 0.0032 & 3.985 & 0.050 & 0.1073 & 0.0005 & 0.938 & 1538 & $\begin{array}{ll}16 \\
\end{array}$ & 1754 \\
\hline 48.1 & 737 & 195 & 0.26 & 158 & - & $<0.01$ & 4.008 & 0.046 & 0.1025 & 0.0005 & 0.2495 & 0.0029 & 3.527 & 043 & 0.1025 & 0005 & 0.934 & 1436 & 15 & 1670 \\
\hline 49.1 & 264 & 77 & 0.29 & 48 & 0.000018 & 0.03 & 4.708 & 0.058 & 0.1017 & 0.0008 & 0.2123 & 0.0026 & 2.970 & 0.044 & 0.1014 & 0.0008 & 0.834 & 1241 & 14. & 1651 \\
\hline 50.1 & 702 & 71 & 0.10 & 173 & 0.000008 & 0.01 & \begin{tabular}{l|l|l}
3.478 & \\
\end{tabular} & 0.041 & 0.1117 & 0.0004 & 0.2875 & 0.0034 & 4.423 & 0.055 & 0.1116 & 0.0004 & 0.950 & 1629 & 17 & 1825 \\
\hline 51.1 & 124 & 102 & \begin{tabular}{l|l|l|}
0.82 \\
\end{tabular} & 23 & 0.000038 & 0.06 & 4.641 & 0.063 & 0.0918 & 0.0010 & 0.2153 & 0.0029 & 2.711 & 0.049 & 0.0913 & 0011 & 0.757 & 1257 & \begin{tabular}{l|l}
15 \\
\end{tabular} & \begin{tabular}{l|l}
1453 \\
\end{tabular} \\
\hline 52.1 & 5453 & 537 & 0.10 & 1052 & 0.000008 & 0.01 & $\begin{array}{ll}4.452 \\
\end{array}$ & 0.046 & 0.0893 & 0.0002 & $\begin{array}{ll}0.2246 \\
\end{array}$ & 0.0023 & 2.761 & 0.029 & 0.0892 & 0.0002 & 0.984 & 1306 & 12 & 1408 \\
\hline 52.2 & 3465 & 444 & 0.13 & \begin{tabular}{l|l|}
648 \\
\end{tabular} & 0.000031 & 0.05 & 4.594 & 0.051 & 0.0893 & 0.0003 & 0.2175 & 0.0024 & 2.666 & 0.031 & 0.0889 & 0.0003 & 0.953 & 1269 & 13 & 1402 \\
\hline 53.1 & 164 & 77 & 0.47 & 41 & - & $<0.01$ & $\begin{array}{l}.443 \\
\end{array}$ & 0.046 & 0.1036 & 0.0008 & 0.2906 & 0.0039 & 4.169 & 0.071 & 0.1040 & 0.0011 & 0.794 & 1644 & 20 & 1698 \\
\hline 54.1 & 109 & 34 & 0.31 & 22 & .000076 & 0.12 & 4.248 & $\begin{array}{ll}0.058 \\
\end{array}$ & 0.1060 & .0012 & 0.2351 & 0.0032 & 3.402 & 0.072 & 0.1049 & 0.0017 & 0.648 & 1361 & 17 & 1713 \\
\hline 55.1 & 170 & 67 & 0.39 & 40 & 0.000001 & 0.00 & 3.620 & $\begin{array}{l}0.046 \\
\end{array}$ & $\begin{array}{l}0.1039 \\
\end{array}$ & 0.0008 & 0.2762 & 0.0035 & 3.957 & 0.061 & $\begin{array}{ll}0.1039 \\
\end{array}$ & 0.0009 & 0.820 & 1572 & 18 & 1695 \\
\hline 56.1 & 312 & 46 & 0.15 & 81 & 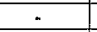 & $<0.01$ & $\begin{array}{l}3.316 \\
\end{array}$ & $\begin{array}{l}0.039 \\
\end{array}$ & 0.1045 & 0.0006 & 0.3017 & .0036 & 4.354 & 0.058 & 0.1047 & 0.0006 & 0.900 & 9700 & 18 & 1709 \\
\hline 57.1 & 592 & 338 & 0.57 & 160 & - & $<0.01$ & 3.172 & 0.036 & 0.1055 & 0.0004 & 0.3152 & .0036 & 4.591 & 0.055 & 然1056 & 0.0004 & 0.947 & 9766 & 18 & 1725 \\
\hline 58.1 & 483 & 301 & 0.62 & 125 & 0.000013 & 0.02 & 3.304 & 0.038 & 0.1061 & 0.0005 & 0.3026 & 0.0035 & 4.421 & 0.055 & 0.1059 & 0.0005 & 0.929 & 1704 & 17 & 1731 \\
\hline 59.1 & 249 & 111 & 0.44 & 70 & - & $<0.01$ & 3.048 & 0.037 & 0.1081 & 0.0007 & 0.3281 & 0.0040 & 4.899 & 0.069 & 0.1083 & 0.0007 & 0.876 & 1829 & 20 & 1771 \\
\hline 60.1 & 186 & 117 & $\begin{array}{l}0.63 \\
0\end{array}$ & 40 & 000035 & 0.06 & 3.978 & 0.050 & 0.0010 & 0.0008 & 0.2612 & 0.0031 & 3.167 & 0.060 & 0.0914 & 0.0000 & 0.800 & 1445 & 16 & 1455 \\
\hline 60.2 & 328 & 99 & 0.30 & 44.3 & 0.000166 & 0.27 & 6.365 & 0.072 & 0.0037 & 0.0007 & 0.1667 & 0.0018 & 1.974 & 0.042 & 0.0914 & 0.0016 & 0.638 & 938 & 10 & 1451 \\
\hline 61.1 & 510 & 246 & 0.48 & 142 & $=$ & $<0.01$ & \begin{tabular}{|l|l}
3.073 \\
\end{tabular} & 0.036 & 0.1268 & 0.0005 & 0.3255 & 0.0038 & \begin{tabular}{|l|l|}
5.692 \\
\end{tabular} & 0.070 & 0.1268 & 0.0005 & 0.943 & 1816 & 18 & 2055 \\
\hline 62.1 & 433 & 184 & 0.42 & 173 & 0.000002 & $<0.01$ & 2.146 & 0.026 & 0.1726 & 0.0006 & 0.4661 & 0.0057 & 11.089 & 0.141 & 0.1726 & \begin{tabular}{|c|}
0.0006 \\
\end{tabular} & 0.956 & 2466 & 25 & 2583 \\
\hline & & & & & & & & & & & & & & & & & & & & \\
\hline & & & & & & & & & & & & & & & & & & & & \\
\hline tes & & 1. Unce & ertainties & s given a & te one o lev & & & & & & & & & & & & & & & \\
\hline & & 2. Error & in FC1 $F$ & Referen: & on calibr & oration & $75 \%$ & $18 \%$ for & e two an & cal sess & & & & & & & & & & \\
\hline & & & & 年 & vorrors & but requI & hence & arling od & Irom dil & ent inoul & & & & & & & & & & \\
\hline & & 3. $\lim _{200} \%$ & ideriole & as lie pe & Cenlage of $\Gamma^{p h}$ & Po that & 3 corrinuen & & & & & & & & & & & & & \\
\hline & & 4. Corm & ection for & or comm & $\mathrm{nPb}$ mado us & ising the & neasured & 206 & alato. & & & & & & & & & & & \\
\hline & & 5. For? & $\%$ Disc, 0 & $0 \%$ ceno & es a concorde & tant anal & & & & & & & & & & & & & & \\
\hline
\end{tabular}


TABLE 3C.-Summary of SHRIMP U-Pb zircon results for sample 95ITz234.

\begin{tabular}{|c|c|c|c|c|c|c|c|c|c|c|c|c|c|c|c|c|c|c|c|c|c|c|c|}
\hline \multirow[b]{2}{*}{ Grain. } & & & & & & & & Total $\mathrm{F}$ & Ratios & & & & Radiogen & ic Ratios & & & & & & & ge (Ma) & & \\
\hline & U & Th & Th/U & ${ }^{206} \mathrm{~Pb}^{4}$ & ${ }^{204} \mathrm{~Pb} /$ & $f_{206}$ & ${ }^{238} \mathrm{UI}$ & & ${ }^{207} \mathrm{~Pb} /$ & & ${ }^{206} \mathrm{Pbl}$ & & ${ }^{207} \mathrm{~Pb} /$ & & ${ }^{207} \mathrm{~Pb}$ & & & & $208 \mathrm{pb}$ & & ${ }^{207} \mathrm{~Pb} /$ & & $\%$ \\
\hline spot & (ppm) & $(\mathrm{ppm}$ & & $(\mathrm{ppm})$ & ${ }^{206} \mathrm{~Pb}$ & $\%$ & ${ }^{206} \mathrm{~Pb}$ & \pm & ${ }^{206} \mathrm{~Pb}$ & \pm & ${ }^{238} \mathrm{U}$ & \pm & ${ }^{235} \mathrm{U}$ & \pm & ${ }^{208} \mathrm{~Pb}$ & \pm & $\rho$ & $\rho$ & ${ }^{238} \mathrm{U}$ & \pm & ${ }^{208} \mathrm{~Pb}$ & \pm & Disc \\
\hline & & & & & & & & & & & & & & & & & & & & & & & \\
\hline 1.1 & 386 & 151 & 0.39 & 109 & 0.000083 & 0.15 & 3.054 & 0.054 & 0.1144 & 0.0006 & 0.3270 & 0.0058 & 5.106 & 0.095 & 0.1133 & 0.0007 & 0.950 & 1.950 & 1824 & 28 & 1852 & 5 & 2 \\
\hline 2.1 & 659 & 131 & 0.20 & 180 & 0.000060 & 0.11 & 3.147 & 0.045 & 0.1103 & 0.0004 & 0.3174 & 0.0045 & 4,793 & 0.071 & 0.1095 & 0.0005 & 0.954 & 1.954 & 1777 & 22 & 1792 & 4 & 1 \\
\hline 3.1 & 291 & 242 & 0.83 & 80 & 0.000103 & 0.19 & 3.122 & 0.048 & 0.1118 & 0.0007 & 0.3197 & 0.0049 & 4.864 & 0.084 & 0.1104 & 0.0009 & 0.887 & 1.887 & 1788 & 24 & 1805. & 7 & -1 \\
\hline 4.1 & 308 & 164 & 0.53 & 82 & 0.000145 & 0.26 & 3.223 & 0.044 & 0.1039 & 0.0007 & 0.3095 & 0.0042 & 4,348 & 0.069 & 0.1019 & 0.0008 & 0.855 & 1.855 & 1738 & 21 & 1659 & 8 & -5 \\
\hline 5.1 & 252 & 98 & 0.39 & 68 & 0.000145 & 0.26 & 3.161 & 0.049 & 0.1094 & 0.0007 & 0.3156 & 0.0049 & 4.672 & 0.088 & 0.1074 & 0.0012 & 0.820 & 1.820 & 1768 & 24 & 1756 & 10 & -1 \\
\hline 6.1 & 217 & 129 & 0.59 & 94 & 0.000141 & 0.25 & 1.970 & 0.030 & 0.1842 & 0.0009 & 0.5062 & 0.0076 & 12.739 & 0.207 & 0.1825 & 0.0011 & 0.924 & 1.924 & 2641 & 33 & 2676 & 5 & . \\
\hline 8.1 & 225 & 142 & 0.63 & 55 & 0.000430 & 0.23 & 3.503 & 0.048 & 0.1002 & 0.0017 & 0.2848 & 0.0039 & 3.866 & 0.089 & 0.0985 & 0.0018 & 0.598 & 1.598 & 1616 & 20 & 1595 & 17 & -1 \\
\hline 9.1 & 592 & 268 & 0.45 & 155 & 0.000083 & 0.15 & 3.285 & 0.054 & 0.1084 & 0.0005 & 0.3040 & 0.0050 & 4.494 & \begin{tabular}{|l|}
0.077 \\
\end{tabular} & 0.1072 & 0.0006 & 0.954 & 1.954 & 1711 & 25 & 1753 & 5 & 2 \\
\hline 10.1 & 227 & 136 & 0.60 & 49 & 0.000035 & 0.06 & 3.979 & 0.060 & 0.0936 & $\mathbf{0 . 0 0 0 8}$ & 0.2512 & 0.0038 & 3.224 & $\begin{array}{ll}0.057 \\
\end{array}$ & 0.0931 & 0.0009 & 0.852 & 1.852 & 1445 & 20 & 1490 & 9 & 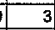 \\
\hline 11.1 & 218 & 65 & 0.30 & 79 & 0.000139 & 0.25 & 2.385 & 0.066 & 0.1739 & 0.0009 & 0.4183 & 0.0115 & 9.930 & 0.284 & $\begin{array}{ll}0.1722 \\
\end{array}$ & 0.0013 & 0.966 & 1.966 & 2253 & 52 & 2579 & 6 & 13 \\
\hline 12.1 & 235 & 94 & 0.40 & 54 & 0.000186 & 0.34 & 3.762 & 0.090 & 0.1114 & 0.0008 & 0.2649 & 0.0063 & 3.976 & 0.103 & 0.1088 & 0.0011 & 0.924 & 1.924 & 1515 & 32 & 1780 & 9 & 15 \\
\hline 13.1 & 76 & 46 & 0.60 & 19 & 0.000286 & 0.52 & 3.540 & 0.053 & 0.1133 & 0.0014 & 0.2810 & 0.0043 & 4.240 & 0.117 & 0.1094 & 0.0025 & 0.556 & 1.556 & $\begin{array}{l}1597 \\
\end{array}$ & 22 & 1790 & 21 & 11 \\
\hline $\begin{array}{l}14.1 \\
\end{array}$ & 554 & 264 & 0.48 & 141 & 0.000048 & \begin{tabular}{|l|}
0.09 \\
\end{tabular} & 3.386 & 0.048 & 0.1065 & 0.0005 & $\begin{array}{l}0.2950 \\
\end{array}$ & 0.0042 & 4.307 & 0.066 & 0.1059 & 0.0006 & $\begin{array}{l}0.939 \\
\end{array}$ & 1.939 & 1667 & 21 & 1729 & 5 & 4 \\
\hline 15.1 & 306 & 268 & 0.88 & 70 & 0.000237 & 0.43 & 3.768 & 0.055 & 0.1004 & 0.0007 & 0.2642 & 0.0038 & 3.540 & 0.063 & 0.0972 & 0.0010 & 0.812 & 1.812 & 1512 & 20 & 1570 & 10 & -1 \\
\hline 16.1 & 120 & 90 & 0.75 & 31 & 0.000241 & 0.43 & 3.282 & 0.052 & 0.1074 & 0.0010 & 0.3034 & 0.0048 & 4.355 & $\begin{array}{l}0.089 \\
\end{array}$ & 0.1041 & 0.0013 & 0.776 & 1.776 & 1708 & 24 & 1699 & 12 & -1 \\
\hline 17.1 & 170 & 85 & 0.50 & 49 & 0.000167 & 0.30 & 2.986 & 0.045 & 0.1132 & 0.0012 & 0.3338 & 0.0051 & 5.105 & 0.118 & 0.1109 & 0.0019 & 0.659 & 1.659 & 1857 & 25 & $\begin{array}{l}1814 \\
\end{array}$ & 16 & -2 \\
\hline 18.1 & 180 & 75 & 0.42 & 52 & 0.000080 & 0.14 & 2.963 & 0.047 & 0.1152 & 0.0009 & 0.3370 & 0.0053 & 5.300 & \begin{tabular}{l|l}
0.094 \\
\end{tabular} & 0.1141 & 0.0009 & 0.894 & 1.894 & 1872 & 26 & 1865 & 7 & 0 \\
\hline 19.1 & 182 & 81 & 0.45 & 47 & 0.000143 & 0.26 & 3.287 & 0.051 & 0.1086 & 0.0013 & 0.3034 & 0.0047 & 4.460 & $\begin{array}{l}0.096 \\
\end{array}$ & 0.1066 & 0.0016 & 0.722 & 1.722 & 1708 & 23 & 1742 & 14 & 2 \\
\hline 20.1 & 150 & 59 & 0.39 & 40 & 0.000122 & 0.22 & 3.207 & 0.046 & 0.1075 & 0.0009 & 0.3111 & 0.0045 & 4.538 & 0.084 & 0.1058 & 0.0012 & 0.779 & 1.779 & 1746 & 22 & 1728 & 11 & -1 \\
\hline 21.1 & 277 & 119 & 0.43 & 76 & 0.000048 & 0.09 & 3.141 & 0.046 & \begin{tabular}{l|l}
0.1127 \\
\end{tabular} & 0.0007 & 0.3181 & 0.0046 & 4.916 & 0.077 & 0.1121 & 0.0007 & 0.925 & 1.925 & 1780 & 23 & $\begin{array}{l}1833 \\
\end{array}$ & 5 & 3 \\
\hline 22.1 & 500 & 145 & 0.29 & 154 & 0.000059 & 0.11 & 2.789 & 0.038 & 0.1183 & 0.0005 & 0.3582 & 0.0049 & 5.804 & \begin{tabular}{l|}
0.084 \\
\end{tabular} & 0.1175 & 0.0006 & 0.934 & 1.934 & 1974 & 23 & 1919 & 5 & -3 \\
\hline 23.1 & 208 & 228 & $\begin{array}{l}0.62 \\
\end{array}$ & 56 & 0.000512 & 0.92 & 3.184 & 0.046 & 0.1088 & 0.0012 & 0.3111 & 0.0045 & 4.364 & \begin{tabular}{l|l}
0.108 \\
\end{tabular} & 0.1017 & 0.0021 & 0.584 & 1.584 & 1746 & 22 & 1656 & 19 & -5 \\
\hline 24.1 & 153 & 70 & 0.46 & 41 & 0.000253 & 0.46 & 3.208 & 0.049 & 0.1069 & 0.0009 & 0.3102 & 0.0048 & 4.422 & 0.087 & 0.1034 & 0.0013 & 0.786 & 1.786 & 1742 & 24 & 1686 & 11 & -3 \\
\hline 25,1 & 382 & 215 & 0.56 & 152 & 0.000016 & 0.03 & 2.162 & 0.030 & 0.1581 & 0.0006 & 0.4624 & 0.0065 & 10.066 & 0.147 & $\begin{array}{l}0.1579 \\
\end{array}$ & 0.0006 & 0.963 & 1.963 & 2450 & 29 & 2433 & 3 & -1 \\
\hline 26.1 & 122 & 454 & 3.72 & 29 & 0.000537 & 0.97 & 3.616 & 0.049 & 0.0993 & 0.0010 & 0.2739 & 0.0038 & 3.468 & 0.086 & 0.0918 & 0.0019 & 0.555 & 1.555 & 1560 & 19 & 1464 & 20 & -7 \\
\hline 27.1 & 315 & 72 & 0.23 & 88 & 0.000137 & 0.25 & 3.058 & 0.042 & 0.1100 & 0.0007 & 0.3262 & 0.0045 & 4.862 & 0.076 & 0.1081 & 0.0008 & 0.871 & 1.871 & 1820 & 22 & 1768 & 7 & -3 \\
\hline 28.1 & 429 & 54 & 0.13 & 119 & 0.000071 & 0.13 & 3.093 & \begin{tabular}{|l|l|}
0.044 \\
\end{tabular} & 0.1110 & 0.0006 & 0.3229 & 0.0046 & 4.897 & 0.075 & 0.1100 & 0.0006 & 0.931 & 1.931 & 1804 & 22 & 1799 & 5 & 0 \\
\hline 29.1 & 190 & \begin{tabular}{|l|l|}
113 \\
\end{tabular} & 0.59 & 47 & 0.000208 & 0.37 & 3.446 & 0.048 & 0.1050 & 0.0009 & 0.2891 & 0.0040 & 4.072 & 0.084 & 0.1022 & 0.0016 & 0.673 & $\begin{array}{l}1.673 \\
\end{array}$ & 1637 & 20 & 1664 & 14 & 2 \\
\hline 30.1 & 80 & 105 & 1.32 & 16 & 0.000868 & 1.57 & $\begin{array}{l}4.239 \\
\end{array}$ & 0.079 & 0.0964 & 0.0029 & 0.2322 & 0.0045 & 2.697 & 0.175 & 0.0842 & 0.0052 & 0.300 & 1.300 & 1346 & 24 & 1298 & 60 & -4 \\
\hline 31.1 & 175 & 76 & 0.44 & 48 & 0.000220 & 0.40 & 3.140 & 0.064 & 0.1126 & 0.0008 & 0.3172 & 0.0064 & 4.793 & 0.109 & 0.1096 & 0.0011 & 0.890 & 1.890 & 1776 & 32 & 1793 & 10 & -1 \\
\hline 32.1 & 199 & 65 & 0.33 & 54 & 0.000148 & 0.27 & 3.156 & 0.064 & 0.1096 & 0.0008 & 0.3161 & 0.0064 & 4.690 & 0.105 & 0.1076 & 0.0010 & 0.905 & 1.905 & 1770 & 31 & 1759 & 9 & -1 \\
\hline 33.1 & 197 & 185 & 0.94 & 41 & 0.000217 & 0.39 & 4.120 & 0.063 & 0.0934 & 0.0012 & 0.2418 & 0.0037 & $3.0+1$ & 0.068 & 0.0903 & 0.0015 & 0.677 & 1.677 & 1396 & 19 & 1432 & 16 & 3 \\
\hline 34.1 & 276 & 95 & 0.34 & 73 & 0.000072 & 0.13 & 3.267 & $\begin{array}{l}0.047 \\
\end{array}$ & 0.1103 & 0.0007 & 0.3057 & $\begin{array}{l}0.0044 \\
\end{array}$ & 4.610 & 0.075 & 0.1094 & 0.0008 & 0.883 & 1.883 & 1720 & 22 & 1789 & 7 & 4 \\
\hline 35.1 & 246 & 155 & 0.63 & 68 & 0.000206 & 0.37 & 3.088 & 0.054 & $\begin{array}{l}0.1099 \\
\end{array}$ & 0.0008 & $\begin{array}{l}0.3227 \\
\end{array}$ & 0.0056 & 4.763 & 0.094 & 0.1071 & 0.0010 & 0.880 & 1.880 & 1803 & 27 & 1750 & 9 & -3 \\
\hline 36.1 & 229 & 80 & 0.35 & 59 & 0.000118 & 0.21 & 3.350 & 0.047 & \begin{tabular}{|l|}
0.1047 \\
\end{tabular} & 0.0007 & \begin{tabular}{|c|}
0.2979 \\
\end{tabular} & 0.0042 & 4.234 & 0.070 & 0.1031 & 0.0009 & 0.844 & 1.844 & 1681 & 21 & 1680 & 8 & 0 \\
\hline 37.1 & 187 & 78 & 0.42 & 48 & 0.000142 & 0.26 & 3.328 & 0.045 & 0.1041 & 0.0008 & 0.2997 & 0.0041 & 4.221 & 0.070 & 0.1021 & 0.0010 & 0.822 & 1.822 & 1690 & 20 & 1663 & 9 & -2 \\
\hline 38.1 & 145 & 89 & 0.62 & 40 & 0.000216 & 0.39 & 3.088 & 0.047 & 0.1095 & 0.0009 & 0.3226 & 0.0050 & 4,741 & 0.100 & 0.1066 & 0.0015 & 0.732 & 1.732 & 1802 & 24 & 1742 & 13 & -3 \\
\hline 39.1 & 381 & \begin{tabular}{|l|}
175 \\
\end{tabular} & 0.46 & 108 & 0.000085 & 0.15 & $\begin{array}{l}3.038 \\
\end{array}$ & \begin{tabular}{|l|l|}
0.054 \\
\end{tabular} & $\begin{array}{l}0.1089 \\
\end{array}$ & 0.0006 & 0.3287 & 0.0058 & 4.883 & 0,092 & 0.1078 & 0.0007 & 0.939 & 1.939 & 1832 & 28 & 1762 & 6 & -4 \\
\hline 40.1 & 334 & 171 & 0.51 & \begin{tabular}{l|l|}
87 \\
\end{tabular} & 0.000112 & 0.20 & 3.286 & 0.049 & \begin{tabular}{|l|}
0.1037 \\
\end{tabular} & 0.0007 & 0.3037 & 0.0046 & 4.277 & 0.075 & 0.4021 & 0.0009 & 0.858 & 1.858 & 1710 & 23 & 1663 & 8 & -3 \\
\hline 41.1 & 553 & 348 & 0.63 & 140 & 0.000097 & 0.17 & 3.391 & 0.050 & \begin{tabular}{|l|l}
0.0997 \\
\end{tabular} & 0.0006 & 0.2944 & 0.0043 & 3.993 & $\begin{array}{ll}0.065 \\
\end{array}$ & 0.0984 & 0.0007 & \begin{tabular}{|c|}
0.897 \\
\end{tabular} & $\begin{array}{l}1.897 \\
\end{array}$ & 1663 & 22 & 1594 & 7 & -4 \\
\hline 42.1 & 387 & 186 & 0.48 & 111 & 0.000116 & 0.21 & 3.002 & 0.043 & $\begin{array}{ll}0.1108 \\
\end{array}$ & 0.0006 & 0.3325 & 0.0047 & 5.005 & 0.079 & 0.1092 & 0.0007 & 0.904 & \begin{tabular}{|l|}
1.904 \\
\end{tabular} & 1850 & 23 & 1786 & 6 & -4 \\
\hline 43.1 & 386 & 121 & 0.31 & 115 & 0.000047 & 0.09 & 2.880 & 0.066 & 0.1164 & 0.0006 & 0.3470 & 0.0079 & 5.540 & $\begin{array}{l}0.132 \\
\end{array}$ & 0.1158 & 0.0007 & 0.963 & 1.963 & 1920 & 38 & 1892 & 6 & -1 \\
\hline 44.1 & 177 & 96 & 0.55 & 49 & 0.000135 & 0.24 & 3.086 & 0.046 & 0.1111 & 0.0014 & 0.3233 & 0.0048 & 4.870 & 0.100 & 0.1093 & 0.0016 & 0.719 & 4.719 & 1806 & 23 & 1787 & 13 & -1 \\
\hline 45.1 & 204 & 82 & 0.40 & 58 & 0.000201 & 0.36 & 3.005 & 0.041 & 0.1120 & 0.0009 & 0.3316 & 0.0045 & 4.997 & 0.086 & \begin{tabular}{|l|l|}
0.1093 \\
\end{tabular} & 0.0011 & 0.794 & 1.794 & 1846 & 22 & 1788 & 9 & -3 \\
\hline 46.1 & 211 & 199 & 0.94 & 46 & 0.000119 & 0.21 & 3.943 & 0.054 & 0.0931 & 0.0008 & 0.2531 & 0.0034 & 3.190 & 0.055 & 0.0914 & 0.0010 & 0.783 & 1.783 & 1454 & 18 & 1455 & 10 & 0 \\
\hline 47.1 & 466 & 102 & 0.22 & 131 & 0.000065 & 0.12 & 3.063 & 0.042 & 0.1094 & 0.0006 & 0.3260 & 0.0044 & 4.880 & 0.073 & 0.1086 & 0.0007 & 0.911 & 1.911 & 1819 & 22 & 1775 & 6 & -2 \\
\hline 48.1 & 1405 & 902. & 0.64 & 390 & 0.000027 & 0.05 & 3.095 & 0.045 & 0.1076 & 0.0003 & 0.3230 & 0.0047 & 4.775 & 0.071 & 0.1072 & 0.0003 & 0.977 & 1.977 & \begin{tabular}{|l|l|}
1804 \\
\end{tabular} & 23 & $\begin{array}{l}1753 \\
\end{array}$ & 3 & -3 \\
\hline 49.1 & 551 & 294 & 0.53 & 144 & 0.000109 & 0.20 & 3.299 & 0.045 & 0.1044 & 0.0005 & 0.3025 & 0.0041 & 4.291 & 0.063 & \begin{tabular}{l|l|}
0.1029 \\
\end{tabular} & 0.0006 & 0.925 & 1.925 & 1704 & 20 & 1677 & 5 & -2 \\
\hline 50.1 & 159 & 110 & 0.69 & 44 & 0.000210 & 0.38 & 3.122 & 0.050 & 0.1090 & 0.0009 & 0.3191 & 0.0052 & 4.670 & 0.098 & $\begin{array}{ll}0.1062 \\
\end{array}$ & 0.0014 & 0.768 & 1.768 & 1785 & 25 & 1735 & 12 & -3 \\
\hline 51.1 & 525 & 321 & 0.61 & 194 & 0.000074 & 0.13 & $\begin{array}{l}2.329 \\
\end{array}$ & 0.037 & 0.1679 & 0.0006 & 0.4289 & 0.0068 & 9.871 & 0.163 & \begin{tabular}{l|l|}
0.1669 \\
\end{tabular} & $\begin{array}{l}0.0008 \\
\end{array}$ & 0.959 & 1.959 & 2301 & 31 & \begin{tabular}{|l|}
2527 \\
\end{tabular} & 4 & 9 \\
\hline 52.1 & 265 & 124 & 0.47 & 70 & 0.000154 & 0.28 & 3.276 & 0.044 & 0.1087 & 0.0007 & 0.3044 & 0.0041 & 4.473 & 0.071 & 0.1066 & 0.0009 & $\begin{array}{l}0.857 \\
\end{array}$ & 1.857 & 1713 & 20 & 1742 & 7 & 2 \\
\hline 53.1 & 228 & 83 & $\begin{array}{ll}0.36 \\
\end{array}$ & 58 & 0.000203 & 0.37 & 3.353 & 0.048 & 0.1061 & 0.0008 & 0.2971 & 0.0042 & 4.233 & 0.075 & \begin{tabular}{|l|l|}
0.1033 \\
\end{tabular} & 0.0011 & 0.811 & 1.811 & 9677 & 21 & 1685 & 10 & 0 \\
\hline 54.1 & 452 & 155 & 0.34 & 122 & 0.000156 & 0.28 & 3.193 & 0.045 & 0.1092 & 0.0007 & 0.3123 & 0.0044 & 4.610 & 0.073 & 0.1071 & 0.0008 & 0.883 & 1.883 & 1752 & 22 & 1750 & 7 & 0 \\
\hline 55.1 & 1322 & 340 & 0.26 & 363 & 0.000036 & $\begin{array}{l}0.07 \\
\end{array}$ & 3.128 & 0.043 & 0.1060 & 0.0003 & 0.3195 & 0.0044 & 4.649 & 0.066 & 0.1055 & 0.0003 & $\begin{array}{ll}0.974 \\
\end{array}$ & 1.974 & 1787 & 22 & 1724 & 3 & -4 \\
\hline 56.1 & 135 & 54 & 0.40 & 39 & 0.000220 & 0.40 & 2.988 & 0.041 & 0.1091 & 0.0010 & 0.3333 & 0.0046 & 4.876 & 0.095 & 0.1061 & 0.0015 & 0.705 & 1.705 & 1854 & 22 & $\begin{array}{l}1733 \\
\end{array}$ & 13 & -7 \\
\hline 57.1 & 161 & 127 & 0.79 & 46 & 0.000290 & 0.52 & 2.988 & \begin{tabular}{|c|}
0.049 \\
\end{tabular} & 0.1101 & 0.0010 & 0.3329 & 0.0056 & 4.871 & 0.138 & 0.1061 & 0.0024 & 0.593 & 1.593 & 1853 & 27 & 1734 & 21 & -7 \\
\hline 58.1 & 502 & 308 & 0.61 & 113 & 0.000143 & 0.26 & 3.820 & \begin{tabular}{l|}
0.057 \\
\end{tabular} & 0.0929 & 0.0005 & 0.2611 & 0.0039 & 3.274 & 0.054 & 0.0909 & 0.0007 & 0.893 & 1.893 & 1496 & 20 & 1445 & 7 & -3 \\
\hline 59.1 & 271 & 79 & 0.29 & 71 & 0.000162 & 0.29 & 3.278 & 0.049 & 0.1090 & 0.0007 & 0,3041 & 0.0046 & 4.477 & 0.077 & 0.1068 & 0.0009 & 0.876 & 1.876 & 1712 & 23 & 1745 & 8 & -1 \\
\hline 60.1 & 653 & 250 & 0.38 & 161 & 0.000076 & 0.44 & 3.484 & 0.047 & 0.1034 & 0.0005 & 0.2867 & 0.0039 & 4.047 & 0.059 & 0.1024 & 0.0005 & 0.934 & 1.934 & 1625 & 19 & 1668 & 5 & 2 \\
\hline & & & & & & & & & & & & & & & & & & & & & & & \\
\hline & & & & & & & & & & & & & & & & & & & & & & & \\
\hline tes : & & 1. Unc & rtalnties & glven & ne one o lev & & & & & & & & & & & & & & & & & & \\
\hline & & 2. Emro & $r \ln R 33$ & referenc & zircon calibr & ation w & $0.66 \%$ & for the an & tical sess & & & & & & & & & & & & & & \\
\hline & & & \{ not inel & Luded In & bove emors b & but requ & Ired when & comparin & & data & rent & & & & & & & & & & & & \\
\hline & & 3. $t_{208}$ & \% denote & os the pe & rcentage of ${ }^{200}$ & Fb tha & is comm & of Pb. & & & & & & & & & & & & & & & \\
\hline & & 4. For & eas of & der than & $-800 \mathrm{Ma}$ corr & ection & or commo & $\mathrm{Pb}$ mad & using the & ${ }_{\text {neasured }}{ }^{20}$ & $\mathrm{~Pb} / 200 \mathrm{~Pb}$ ra & & & & & & & & & & & & \\
\hline & & 5 & areas yo & sunger th & an $-800 \mathrm{Ma}$ & -5 & n for com & non $\mathrm{Pb}$ & de using & 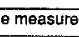 & 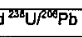 & - & b ra & & & & & & & & & & \\
\hline & & & following & Tera an & d Wasserburg & $(1972$ & as outtin & d In Willia & Ims (1998). & & & & & & & & & & & & & & \\
\hline & & 6. For & $\%$ Disc, & $0 \%$ deno & tes a concord & lant an & |ysls. & & & & & & & & & & & & & & & & \\
\hline
\end{tabular}


TABLE 3D.-Summary of SHRIMP U-Pb zircon results for sample 02RL888.

\begin{tabular}{|c|c|c|c|c|c|c|c|c|c|c|c|c|c|c|c|c|c|c|c|c|c|c|}
\hline & & & & & & & & Total R & atios & & & & Radiogeni & Ratios & & & & & & e (Ma) & & \\
\hline Grain. & $u$ & $\mathrm{Th}$ & $\mathrm{Th} / \mathrm{U}$ & $\mathrm{Pb}^{*}$ & ${ }^{204} \mathrm{~Pb} /$ & $f_{208}$ & ${ }^{238} \mathrm{U} /$ & & ${ }^{207} \mathrm{~Pb} /$ & & ${ }^{206} \mathrm{~Pb} /$ & & ${ }^{207} \mathrm{~Pb} /$ & & ${ }^{207} \mathrm{~Pb} /$ & & & $206 \mathrm{~Pb} /$ & & ${ }^{207} \mathrm{~Pb} /$ & & $\%$ \\
\hline spot & (ppm) & (ppm) & & (ppm) & ${ }^{206} \mathrm{~Pb}$ & $\%$ & ${ }^{206} \mathrm{~Pb}$ & \pm & ${ }^{208} \mathrm{~Pb}$ & \pm & ${ }^{238} \mathrm{U}$ & \pm & ${ }^{235} \mathrm{U}$ & \pm & ${ }^{200} \mathrm{~Pb}$ & \pm & $\rho$ & ${ }^{230} \mathrm{U}$ & \pm & ${ }^{206} \mathrm{pb}$ & \pm & Disc \\
\hline & & & & & & & & & & & & & & & & & & & & & & \\
\hline 1.1 & 346 & 157 & 0.45 & 90 & 0.000021 & 0.03 & 3.296 & 0.038 & 0.1054 & 0.0005 & 0.3033 & 0.0035 & 4.396 & $\begin{array}{l}0.055 \\
\end{array}$ & \begin{tabular}{|c|}
0.1051 \\
\end{tabular} & 0,0005 & 0.922 & 1708 & 17 & \begin{tabular}{|l|l|}
1716 \\
\end{tabular} & $\mathbf{9}$ & 1 \\
\hline 2.1 & 253 & 38 & 0.15 & 68 & 0.000017 & 0.03 & 3.214 & 0.053 & 0.1083 & 0.0006 & 0.3110 & 0.0052 & \begin{tabular}{|l|}
4.633 \\
\end{tabular} & 0.081 & 0.1080 & 0.0006 & 0.949 & 1746 & 25 & 1767 & 10 & 1 \\
\hline 3.1 & 264 & 129 & 0.49 & 78 & 0.000004 & 0.01 & 2.915 & 0.035 & 0.1140 & 0.0005 & 0.3430 & 0.0041 & 5.390 & 0.070 & 0.1140 & 0.0006 & 0.928 & 1901 & 20 & 1864 & 9 & -2 \\
\hline 4.1 & 861 & 2063 & 2.40 & 190 & 0,000005 & 0.01 & 3.896 & 0.042 & 0.0933 & 0.0004 & 0.2567 & 0.0027 & 3.301 & 0.038 & 0.0933 & 0.0004 & 0.937 & 1473 & 14 & 1494 & 8 & 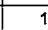 \\
\hline 5.1 & 232 & 163 & 0.70 & 51 & 0,000055 & 0.09 & 3.904 & 0.047 & 0.0990 & 0.0008 & 0.2559 & 0.0031 & 3.469 & 0.050 & 0.0983 & 0.0008 & 0.832 & 1469 & 16 & 1592 & 15 & 8 \\
\hline 6.1 & 591 & 67 & 0.11 & 153 & 0.000021 & 0.03 & 3.329 & 0.038 & 0.1039 & 0.0004 & 0.3003 & 0.0035 & 4.290 & 0.053 & 0.1036 & 0.0005 & 0.925 & 1693 & 17 & 1690 & 9 & 0 \\
\hline 7.1 & 208 & 78 & 0.38 & 55 & 0.000060 & 0.09 & 3.277 & 0.040 & 0.1036 & 0.0007 & 0.3049 & 0.0038 & 4.323 & 0.062 & 0.1028 & 0.0008 & 0.855 & 1715 & 19 & 1676 & 14 & -2 \\
\hline 8.1 & 199 & 84 & 0.42 & 55 & 0.000009 & 0.01 & 3.090 & $\begin{array}{l}0.038 \\
\end{array}$ & 0.1084 & 0.0007 & 0.3236 & 0.0040 & 4.832 & 0.068 & 0.1083 & 0.0007 & 0.878 & 1807 & 19 & 1771 & 12 & -2 \\
\hline 9.1 & 745 & 152 & 0.20 & 199 & 0.000006 & 0.01 & 3.216 & 0.036 & 0.1059 & 0.0004 & 0.3109 & 0.0035 & 4.538 & 0.054 & 0.1059 & 0.0004 & 0.949 & 1745 & 17 & 1729 & 7 & -1 \\
\hline 10.1 & 175 & 63 & 0.36 & 37 & - & $<0.01$ & 4.108 & 0.058 & 0.1099 & 0.0010 & 0.2434 & 0,0034 & 3.689 & 0.062 & 0.1099 & 0.0010 & 0.834 & 1404 & 18 & 1798 & 17 & 22 \\
\hline 11.1 & 237 & 76 & 0.32 & 65 & 0.000044 & 0.07 & 3.130 & $\begin{array}{l}0.047 \\
\end{array}$ & 0.1092 & 0.0006 & 0.3193 & 0.0048 & 4.782 & $\begin{array}{l}0.079 \\
\end{array}$ & 0.1086 & 0.0007 & 0.915 & $\begin{array}{l}1786 \\
\end{array}$ & 24 & 1777 & 12 & -1 \\
\hline 12.1 & 995 & 153 & 0.15 & 280 & 0.000018 & 0.03 & 3.051 & 0.035 & 0.1059 & 0.0003 & 0.3277 & 0.0038 & 4.772 & 0.058 & 0.1056 & 0.0004 & 0,960 & 1827 & 18 & 1725 & 6 & -6 \\
\hline 13.1 & 274 & 80 & 0.29 & 73 & 0.000062 & 0.10 & 3.214 & 0.038 & 0.1049 & 0.0006 & 0.3109 & 0.0037 & 4.460 & 0.060 & 0.1040 & 0.0007 & 0,884 & 1774 & 18 & 9698 & 12 & -3 \\
\hline 14.1 & 368 & 195 & 0.53 & 94 & 0.000019 & 0.03 & 3.375 & 0.041 & 0.1082 & 0.0005 & 0.2962 & 0.0036 & 4.407 & 0.057 & 0.1079 & 0.0005 & 0.928 & 1673 & 18 & 1764 & 9 & 5 \\
\hline 15.1 & 165 & 90 & 0.55 & 46 & 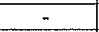 & $<0.01$ & 3.083 & 0.039 & 0.1090 & 0.0008 & 0.3245 & 0.0041 & 4.887 & 0.072 & 0.1092 & 0.0009 & 0.848 & 1811 & 20 & 1787 & 14 & -1 \\
\hline 16.1 & 366 & 98 & 0.27 & 92 & 0.000052 & 0.08 & 3.432 & 0.039 & 0.1059 & 0.0005 & 0.2911 & 0.0033 & \begin{tabular}{|l|l|}
4.223 \\
\end{tabular} & 0.053 & 0.1052 & 0.0006 & 0.908 & 1647 & 17 & 1718 & 10 & 4 \\
\hline 17.1 & 983 & 160 & 0.16 & 276 & 0.000017 & 0.03 & 3.057 & 0.034 & 0.1136 & 0.0003 & 0.3270 & 0.0036 & 5.111 & 0.059 & 0.1134 & 0.0003 & 0.965 & 1824 & 18 & 1854 & 5 & 2 \\
\hline 18.1 & 533 & 27 & 0.05 & 129 & 0.000014 & 0.02 & 3.535 & 0.040 & 0.1023 & 0.0004 & 0.2828 & 0.0032 & 3.983 & 0.050 & 0.1021 & 0.0005 & 0.919 & 1606 & 16 & 1663 & 9 & 3 \\
\hline 19.1 & 148 & 44 & 0.30 & 38 & 0.000050 & 0.08 & 3.302 & 0.048 & 0.1054 & 0.0008 & $\begin{array}{c}0.3026 \\
\end{array}$ & 0.0044 & 4.369 & 0.074 & 0.1047 & 0.0009 & 0.865 & 1704 & 22 & 1709 & 16 & 0 \\
\hline 20.1 & 181 & 75 & 0.41 & 47 & 0.000007 & 0.01 & 3.335 & 0.053 & 0.1073 & 0.0009 & 0.2998 & 0.0047 & $\begin{array}{l}4.432 \\
\end{array}$ & 0.079 & 0.1072 & 0.0009 & 0.890 & 1690 & 23 & \begin{tabular}{|l|}
1753 \\
\end{tabular} & 15 & 4 \\
\hline 21.1 & 210 & 91 & 0.44 & 55 & 0.000052 & 0.08 & 3.253 & 0.039 & 0.1072 & 0.0007 & 0.3072 & 0,0037 & 4.510 & 0.063 & 0.1065 & 0.0008 & 0.860 & $\begin{array}{l}1727 \\
\end{array}$ & 18 & \begin{tabular}{|l|}
1740 \\
\end{tabular} & 13 & -1 \\
\hline 22.1 & 142 & 83 & 0.58 & 30 & 0.000050 & 0.08 & 4.053 & 0.053 & 0.0929 & 0.0009 & 0.2465 & 0.0032 & 3.135 & 0.052 & 0.0922 & 0.0009 & $\begin{array}{l}0.786 \\
\end{array}$ & 1420 & 17 & 1472 & $\begin{array}{l}19 \\
\end{array}$ & 4 \\
\hline 23.1 & 917 & 209 & 0.23 & 258 & 0.000007 & 0.01 & 3.058 & 0.034 & 0.1109 & 0.0003 & 0.3270 & 0.0036 & 4.995 & 0.057 & 0.1108 & 0.0003 & 0.965 & 1824 & 18 & 1813 & 5 & -1 \\
\hline 24.1 & 726 & 34 & 0.05 & 206 & 0.000043 & 0.07 & 3.024 & 0.034 & 0.1059 & 0.0004 & 0.3305 & 0.0037 & 4.800 & 0.058 & 0.1053 & 0.0004 & 0.942 & 1841 & 18 & 1720 & 7 & .7 \\
\hline 25.1 & 103 & 56 & 0.54 & 38 & - & $<0.01$ & 2.316 & 0.031 & 0.1614 & 0.0011 & 0.4322 & 0.0057 & 9.659 & 0.146 & 0.1621 & 0.0012 & 0.874 & 2316 & 26 & 2478 & 12 & 7 \\
\hline 26.1 & 289 & 244 & 0.85 & 62 & 0.000007 & 0.01 & 3.997 & 0.046 & 0.0912 & 0.0006 & 0.2501 & 0.0029 & \begin{tabular}{|l|l|}
3.142 \\
\end{tabular} & 0.044 & 0.0911 & 0.0007 & 0.836 & 1439 & 15 & 1449 & 15 & 1 \\
\hline 27.1 & 484 & 175 & 0.36 & 141 & 0.000011 & 0.02 & 2.950 & 0.034 & 0.1087 & 0.0004 & 0.3389 & 0.0039 & 5.071 & 0.062 & 0.1085 & 0.0005 & 0.935 & 1881 & 19 & 1775 & 8 & -6 \\
\hline 28.1 & 295 & 123 & 0.42 & 74 & 0.000085 & 0.14 & 3.427 & 0.040 & 0.1032 & 0.0007 & 0.2914 & 0.0034 & 4.100 & 0.056 & 0.1020 & 0.0007 & 0.848 & 1649 & 17 & 1661 & 13 & 1 \\
\hline 29.1 & 58 & 48 & 0.84 & 14 & 0.000096 & 0.15 & \begin{tabular}{|l|l|}
3.627 \\
\end{tabular} & 0.058 & 0.1011 & 0.0015 & 0.2753 & 0.0044 & \begin{tabular}{|l|}
3.787 \\
\end{tabular} & 0.083 & 0.0998 & 0.0015 & 0.734 & 1568 & 22 & 1620 & 28 & 3 \\
\hline 30.1 & 388 & 143 & 0.37 & 102 & 0.000036 & 0.06 & \begin{tabular}{|l|}
3.264 \\
\end{tabular} & \begin{tabular}{|c|}
0.038 \\
\end{tabular} & 0.1048 & 0.0005 & 0.3062 & 0.0036 & 4.404 & \begin{tabular}{|c|}
0.056 \\
\end{tabular} & 0.1043 & 0.0005 & 0.912 & 1722 & 18 & 1702 & 10 & -1 \\
\hline 31.1 & 566 & 92 & 0.16 & 153 & 0.000013 & 0.02 & \begin{tabular}{|l|l|}
3.179 \\
\end{tabular} & 0.037 & 0.1071 & 0.0004 & 0.3145 & 0.0036 & 4.637 & 0.057 & 0.1069 & 0.0005 & 0.934 & 4763 & 18 & 1748 & 8 & -1 \\
\hline 32.1 & 446 & 41 & 0.09 & 119 & - & $<0.01$ & 3.229 & 0.038 & 0.1050 & 0.0005 & 0.3097 & 0.0036 & 4.487 & 0.057 & 0.1051 & 0.0005 & 0.928 & $\begin{array}{l}1739 \\
\end{array}$ & 18 & 1716 & 9 & -1 \\
\hline 33.1 & 231 & 51 & 0.22 & 48 & 0.000340 & \begin{tabular}{|l|l|}
0.54 \\
\end{tabular} & 4.111 & 0.052 & 0.1071 & 0.0014 & 0.2420 & 0.0031 & 3.417 & 0.076 & 0.1024 & 0.0019 & 0.575 & 1397 & 16 & \begin{tabular}{|c|}
1669 \\
\end{tabular} & 34 & 16 \\
\hline 34.1 & 733 & 99 & 0.14 & 207 & 0.000019 & 0.03 & 3.039 & 0.034 & 0.1105 & 0.0004 & $\begin{array}{l}0.3292 \\
\end{array}$ & 0.0037 & 5.026 & 0.059 & 0.1107 & 0.0004 & 0.958 & 1834 & 18 & 1812 & 6 & -1 \\
\hline 35.1 & 378 & 197 & 0.52 & 97 & 0.000002 & $<0.01$ & 3.340 & 0.039 & 0.1015 & 0.0005 & 0.2994 & 0.0035 & 4.189 & 0.053 & 0.1015 & 0.0005 & 0.923 & 1688 & 17 & 1651 & 9 & -2 \\
\hline 36.1 & 1419 & 8 & 0.01 & 373 & 0.000028 & 0.05 & 3.273 & \begin{tabular}{l|l}
0.036 \\
\end{tabular} & 0.1010 & 0.0003 & 0.3054 & 0.0034 & 4.235 & 0.049 & 0.1006 & 0.0003 & 0.966 & 1718 & 17 & \begin{tabular}{|l|}
1635 \\
\end{tabular} & 6 & -5 \\
\hline 37.1 & 365 & 172 & 0.47 & 88 & 0.000096 & 0.15 & 3.556 & 0.043 & 0.0971 & 0.0006 & 0.2808 & 0.0034 & 3.709 & 0.053 & 0.0958 & 0.0008 & 0.834 & 1595 & 17 & 1544 & 15 & -3 \\
\hline 38.1 & 293 & 46 & 0.16 & 80 & 0.000073 & 0.11 & 3.147 & 0.038 & 0.1088 & 0.0006 & 0.3175 & 0.0038 & 4.739 & 0.063 & 0.1082 & 0.0006 & 0.904 & 1778 & 19 & 1770 & 10 & 0 \\
\hline 39.1 & 308 & 97 & 0.31 & 60 & 0.000131 & 0.20 & 4.381 & 0.066 & 0.1232 & 0.0029 & 0.2244 & 0.0034 & 3.397 & 0.117 & 0.1098 & 0.0034 & 0.433 & 1305 & 19 & \begin{tabular}{|l|}
1796 \\
\end{tabular} & 57 & 27 \\
\hline 40.1 & 152 & 67 & 0.44 & 43 & 0.000065 & 0.10 & 3.043 & 0.040 & 0.1094 & 0.0000 & 0.3283 & 0.0043 & 4.914 & 0.076 & 0.1086 & 0.0000 & 0.849 & 1830 & 21 & 1776 & 15 & -3 \\
\hline 41.1 & 554 & 218 & 0.39 & 155 & 0.000029 & 0.05 & 3.069 & $\begin{array}{l}0.036 \\
\end{array}$ & 0.1099 & 0.0005 & 0.3257 & 0.0038 & 4.918 & 0.062 & 0.1095 & 0.0005 & 0.929 & 1817 & 18 & 1791 & 8 & -1 \\
\hline 42.1 & 782 & 252 & \begin{tabular}{l|l|}
0.32 \\
\end{tabular} & 210 & 0.000046 & 0.07 & 3.197 & 0.036 & 0.1067 & 0.0004 & 0.3126 & 0.0036 & 4.573 & 0.055 & 0.1061 & 0.0004 & 0.943 & 1753 & 17 & 1734 & 7 & -1 \\
\hline 43.1 & 134 & 440 & 1.05 & 33 & 0.000041 & 0.06 & 3.461 & \begin{tabular}{|c|}
0.047 \\
\end{tabular} & 0.1040 & 0.0010 & 0.2887 & 0.0039 & 4.118 & 0.069 & 0.1034 & 0.0010 & 0.807 & 1635 & 20 & 1687 & 18 & 3 \\
\hline 44.1 & 330 & 108 & 0.33 & 96 & 0.000062 & 0.10 & 2.955 & 0.037 & 0.1113 & \begin{tabular}{l||}
0.0006 \\
\end{tabular} & 0.3381 & 0.0042 & 5.152 & 0.071 & 0.1105 & 0.0006 & 0.907 & 1878 & 20 & 1808 & 10 & -4 \\
\hline 45.1 & 1021 & 432 & $\begin{array}{l}0.42 \\
\end{array}$ & 274 & 0.000050 & 0.08 & 3.204 & 0.037 & 0.1042 & 0.0004 & 0.3119 & 0.0036 & 4.451 & 0.054 & 0.1035 & 0.0004 & 0.945 & 1750 & 18 & 1688 & 7 & -4 \\
\hline 46.1 & 450 & 96 & 0.21 & \begin{tabular}{l|}
138 \\
\end{tabular} & 0.000062 & 0.09 & 2.800 & 0.032 & 0.1229 & 0.0009 & 0,3568 & 0.0041 & 6.005 & 0.085 & 0.1221 & 0.0010 & 0.820 & 1967 & 20 & 1987 & 14 & $\overline{1}$ \\
\hline 47.1 & 215 & 310 & 1.44 & 49 & 0.000019 & 0.03 & 3.750 & 0.047 & 0.0942 & 0.0007 & 0.2666 & 0.0033 & 3.452 & 0.051 & 0.0939 & 0.0008 & $\begin{array}{ll}0.842 \\
\end{array}$ & 1524 & 17 & 1506 & 15 & -1 \\
\hline 48.1 & 100 & 46 & 0.46 & 29 & 0.000054 & 0.08 & 2.911 & 0.040 & 0.1170 & 0.0010 & 0.3433 & 0.0047 & 5.504 & 0.102 & 0.1163 & 0.0014 & 0.747 & 1902 & 23 & 1900 & 22 & 0 \\
\hline 49.1 & 406 & 73 & 0.18 & 108 & 0.000000 & 0.00 & 3.236 & 0.038 & 0.1041 & 0.0005 & 0.3090 & 0.0036 & 4.436 & 0.057 & 0.1041 & 0.0005 & 0.919 & 1736 & 18 & 1699 & 9 & -2 \\
\hline 50.1 & 743 & 112 & \begin{tabular}{l|l}
0.15 \\
\end{tabular} & 192 & 0.000022 & 0.04 & 3.326 & $\begin{array}{l}0.038 \\
\end{array}$ & 0.1036 & 0.0004 & 0.3007 & 0.0034 & 4.299 & 0.051 & 0.1037 & 0.0004 & 0.953 & 1695 & 17 & 1691 & 7 & 0 \\
\hline 51.1 & 222 & 69 & 0.31 & 45 & 0.000008 & 0.01 & 4.265 & 0.051 & 0.0914 & 0.0008 & 0.2344 & 0.0028 & 2.950 & 0.044 & 0.0913 & 0.0008 & 0.802 & 1358 & 15 & $\begin{array}{l}1452 \\
\end{array}$ & 17 & 7 \\
\hline 52.1 & 283 & 79 & 0.28 & 78 & 0.000032 & 0.05 & 3.094 & 0.037 & 0.1097 & 0.0006 & 0.3230 & 0.0039 & 4.866 & 0.065 & 0.1093 & 0.0006 & 0.896 & 1804 & 19 & 1787 & 11 & -1 \\
\hline 53.1 & 736 & 84 & 0.11 & 194 & 0.000007 & 0.01 & 3.257 & 0.037 & 0.1035 & 0.0004 & $\begin{array}{l}0.3070 \\
\end{array}$ & $\begin{array}{ll}0.0035 \\
\end{array}$ & \begin{tabular}{|l|}
4.377 \\
\end{tabular} & 0.052 & 0.1034 & 0.0004 & 0.951 & 1726 & $17 \mid$ & 1686 & 7 & -2 \\
\hline 54.1 & 513 & 121 & 0.24 & 113 & 0.000041 & 0.07 & 3.895 & 0.045 & 0.0933 & 0.0005 & 0.2566 & 0.0030 & 3.279 & 0.043 & 0.0927 & 0.0006 & 0.888 & 1472 & 15 & 1481 & 111 & 1 \\
\hline 54.1 & 626 & 133 & 0.21 & 142 & 0.000024 & 0.04 & 3.787 & 0.041 & 0.0912 & 0.0004 & 0.2639 & 0.0029 & 3.305 & 0.040 & 0.0908 & 0.0005 & \begin{tabular}{ll|}
0.908 \\
\end{tabular} & 1510 & 15 & 1443 & 10 & -5 \\
\hline 55.1 & 142 & 62 & 0.44 & 39 & - & $<0.01$ & \begin{tabular}{|l|}
3.089 \\
\end{tabular} & \begin{tabular}{|l|}
0.040 \\
\end{tabular} & 0.1098 & 0.0010 & 0,3237 & 0.0042 & 4.908 & 0.078 & 0.1099 & 0.0010 & 0.815 & 1808 & 20 & 4799 & \begin{tabular}{|r|}
17 \\
\end{tabular} & -1 \\
\hline 56.1 & 418 & 129 & 0.31 & 109 & 0.000021 & 0.03 & 3.298 & 0.038 & 0.1046 & 0.0005 & 0.3031 & 0.0035 & 4.361 & $\begin{array}{l}0.055 \\
\end{array}$ & 0.1044 & 0.0005 & 0.920 & 1707 & 17 & 1703 & 9 & 0 \\
\hline 57.1 & 49 & 27 & 0.56 & 13 & 0.000032 & 0.05 & 3.136 & 0.050 & 0.1055 & 0.0014 & \begin{tabular}{|l|}
0.3187 \\
\end{tabular} & 0,0051 & 4.618 & 0.111 & 0.1051 & 0.0019 & 0.662 & 1783 & 25 & 1796 & 33 & -4 \\
\hline 58.1 & 36 & 27 & 0.75 & 10 & - & $<0.01$ & 3.202 & 0.053 & 0.1080 & 0.0016 & 0.3129 & 0.0052 & 4.724 & 0.116 & 0.1095 & 0.0020 & 0.680 & 1755 & 26 & 1791 & 33 & 2 \\
\hline 58.2 & 67 & 77 & 1.14 & 16 & - & $<0.01$ & 3.506 & 0.051 & 0.1031 & 0.0012 & 0.2853 & 0.0041 & 4.067 & 0.075 & 0.1034 & 0.0012 & 0.786 & 1618 & 21 & 1686 & 21 & 4 \\
\hline 59.1 & 248 & 200 & 0.80 & 56 & 0.000066 & 0.11 & 3.781 & 0.046 & 0.0933 & 0.0006 & 0.2642 & 0.0032 & 3.365 & 0.049 & 0.0924 & 0.0007 & 0.832 & 1511 & 16 & 1475 & 15 & -2 \\
\hline 60.1 & 234 & 63 & 0.27 & 68 & $\pi$ & $<0.01$ & 2.959 & 0.036 & 0.1096 & 0.0007 & 0.3380 & 0.0042 & 5.106 & 0.071 & 0.1096 & 0.0007 & 0.882 & 1877 & 20 & 1792 & 12 & -5 \\
\hline 61.1 & 535 & 93 & 0.17 & 135 & 0.000035 & 0.06 & 3.397 & 0.039 & 0.1035 & 0.0004 & 0.2942 & 0.0033 & 4.179 & 0.051 & 0.1030 & 0.0004 & 0.934 & 1662 & 17 & 1679 & 8 & 1 \\
\hline 62.1 & 384 & 292 & 0.76 & 81 & 0.000066 & 0.11 & 4.083 & 0.053 & 0.0909 & 0.0005 & 0.2449 & 0.0032 & 3.064 & 0.044 & 0.0908 & 0.0005 & 0.907 & 1412 & 18 & 1442 & 12 & 2 \\
\hline 63.1 & 418 & 145 & 0.35 & 112 & 0.000027 & 0.04 & 3.219 & 0.039 & 0.1092 & 0.0005 & 0.3105 & 0.0037 & 4.660 & 0.061 & 0.1088 & 0.0006 & 0.921 & 1743 & 18 & 1780 & 9 & 2 \\
\hline & & & & & & & & & & & & & & & & & & & & & & \\
\hline tes : & & 1. Uncer & tainties $\mathrm{g}$ & given a & one o leve & & & & & & & & & & & & & & & & & \\
\hline & & 2. Error is & $\mathrm{nFC1} \mathrm{Re}$ & eference & zircon calibre & ration we & $.75 \%$ & $48 \%$ for & the two ar & tical se & & & & & & & & & & & & \\
\hline & & 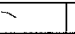 & (not incl & luded in & above errors & but req & ired when & comparin & g data fron & different $m$ & ounts). & & & & & & & & & & & \\
\hline & & 3. $f_{206} \%$ & denotes & the per & entage of ${ }^{206} \mathrm{P}$ & $\mathrm{Pb}$ that & common & & & & & & & & & & & & & & & \\
\hline & & 4. Correc & ction for c & commor & $\mathrm{Pb}$ made usi & Sing the & רeasured & ${ }^{4} \mathrm{~Pb} / 206 \mathrm{Cb}$ & ratio. & & & & & & & & & & & & & \\
\hline & & 5. For $\%$ & Disc, $0 \%$ & $6 \mathrm{denot}$ & s a concorda & ant analy & & & & & & & & & & & & & & & & \\
\hline
\end{tabular}


TABLE 3E.-Summary of SHRIMP U-Pb zircon results for sample SS-95-19A.

\begin{tabular}{|c|c|c|c|c|c|c|c|c|c|c|c|c|c|c|c|c|c|}
\hline & & & & & & & & Total F & atios & & & & Radiogeni & Ratios & & & \\
\hline Grain. & $\mathrm{u}$ & In & Thu & $\mathrm{Pb}^{*}$ & $20 \mathrm{pbl}$ & $f_{200}$ & ${ }^{20} \mathrm{U} /$ & & ${ }^{207} \mathrm{~Pb} /$ & & $\mathrm{Fb} /$ & & & & $200 \mathrm{~Pb} /$ & & \\
\hline spot & ppm) & $(\mathrm{ppm})$ & & \begin{tabular}{|l|l}
$(\mathrm{ppm})$ \\
\end{tabular} & $20 \times p$ & $\%$ & $20 \mathrm{pob}^{2}$ & \pm & ${ }^{20 \mathrm{pb} b}$ & \pm & 200 & \pm & ह5i & \pm & ${ }^{200 \mathrm{~Pb}}$ & \pm & $p$ \\
\hline & 629 & 251 & 0.40 & 165 & & 0.02 & 3.27 & & 0.10 & 000 & .30 & 0.0032 & 4.52 & & & & 92 \\
\hline 2.1 & $\overleftarrow{884}$ & 517 & 076 & 188 & & 0 & 3.494 & & & 0004 & 028 & & & & 0.0994 & & 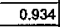 \\
\hline 3.1 & 633 & 247 & 0.39 & 77 & & & - & & 0.106 & & $\overline{0.324}$ & 0041 & & & & & \\
\hline & 278 & 104 & 0.37 & 75! & 00250 & 0,39 & 201 & & 0.11 & 0.0010 & & 0042 & 4.6 & 089 & 0.1084 & & 702 \\
\hline & $\frac{8183}{723}$ & $\frac{1942}{169}$ & $\begin{array}{l}0.37 \\
0.23\end{array}$ & $\begin{array}{c}1685 \\
190\end{array}$ & 0.0000008 & 0.01 & $\begin{array}{l}3.153 \\
3.376\end{array}$ & $\begin{array}{l}0.035 \\
0.037\end{array}$ & D..0999 & 0.0003 & 0.317 & 0.0035 & $\begin{array}{r}4.441 \\
478 \mathrm{~B}\end{array}$ & 0.051 & $\begin{array}{l}0.1014 \\
0.0046\end{array}$ & $\frac{0.0003}{0.00005}$ & 0.960 \\
\hline & 487 & 318 & 0.65 & 125 & 0.000083 & \begin{tabular}{|l|}
$|0.43|$ \\
\end{tabular} & 3.351 & 0.0039 & 0.1061 & $\frac{0.0007}{0.0007}$ & 0.2980 & 0.0035 & 4.314 & 0.059 & 0.1050 & 0.0008 & 0.952 \\
\hline 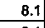 & & & 0.45 & 176 & 0.0000061 & \begin{tabular}{|l|l|} 
\\
\end{tabular} & 3.318 & 0.042 & $\begin{array}{l}0.1013 \\
\end{array}$ & $\begin{array}{l}0.0006 \\
\end{array}$ & 0.0 .3022 & 0.0038 & 4 & 0.062 & $\begin{array}{l}0.1036 \\
\end{array}$ & 0.0007 & 0.882 \\
\hline 3 & 665 & 263 & $\begin{array}{l}0.39 \\
\end{array}$ & 153 & 0.000052 & 0.08 & & 0.046 & 0.1083 & & 0.2678 & 0.0033 & 3.4 & $\begin{array}{l}057 \\
77\end{array}$ & 0.1056 & 0.0008 & 0.837 \\
\hline 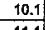 & & & 0.96 & 497| & & & 2.934 & 0.035 & & & & & & & & & 0.863 \\
\hline 111.1 & $\frac{1378}{861}$ & $\begin{array}{l}3666 \\
366 \\
\end{array}$ & 0.27 & $\begin{array}{l}560 \\
28\end{array}$ & & & 2.109 & & 0.1637 & 0005 & 474 & .0054 & & & 0.1637 & & 0.963 \\
\hline 13.1 & 867 & $\begin{array}{c}366 \\
72 \\
72\end{array}$ & . 0.42 & $\begin{array}{r}228 \\
30\end{array}$ & 0.000093 & 0.15 & $\begin{array}{l}3.2445 \\
3.555\end{array}$ & 0.05 & 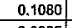 & 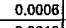 & 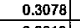 & 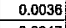 & In & & 0.1067 & & 0.866 \\
\hline 14. & 500 & 202 & 0.40 & 134. & 0.000005 & \begin{tabular}{|l|l|}
0.01 \\
0.01
\end{tabular} & $\begin{array}{l}3.555 \mid \\
3.239 \\
\end{array}$ & $\frac{0.059}{0.041}$ & 0.098 & 0.001 & 0.2813 & 0.0447 & 3.82 & 0.089 & 0.0985 & 0.0. & 0715] \\
\hline & 328 & 136 & 0.42 & 87 & & \begin{tabular}{|l|}
$<0.01$ \\
\end{tabular} & 3.253 & 0.043 & $\begin{array}{l}0.10569 \\
0.1056\end{array}$ & $\begin{array}{l}0.000018 \\
0.00010\end{array}$ & $\begin{array}{l}0.3087 \\
0.3079\end{array}$ & $\frac{0.0398}{0.0041}$ & $\begin{array}{r}-4.470 \\
4.546\end{array}$ & $\frac{0.066}{0.0811}$ & $\mid \frac{0.1050}{0.1071}$ & $\frac{0.00008}{0.0013}$ & $\begin{array}{l}0.856 \\
0.747\end{array}$ \\
\hline 16. & & 451! & 0.65 & 154 & 0.00041 & 0.07 & 976 & 0.045 & 0.0920 & 0.0005 & 0.2514 & 0.0029 & 3.170 & 0.042 & 0.0915 & 0.0006 & 0.866 \\
\hline & 602 & 3081 & 0.51 & 155 & 0.000005 & 0.08 & 3.3.311 & 0.038 & 0.1082 & 0006 & $\mathbf{0 . 3 0 0 0}$ & 0.0034 & 4.3 & 0.057 & 0.10 & & 0.879 \\
\hline & & & 0.53 & & 0.0000391 & & & .034 & & & & 0.0036 & & 0.056 & & & 0.923 \\
\hline $\begin{array}{l}20.1 \\
20.1\end{array}$ & 年 & 20 & 0,10 & 141 & & 00.01 & & 1039 & 1083 & & 0.3289 & 0.0042 & 4.5 & & 0.106 & & 333. \\
\hline 21.1 & 348 & 106 & 0 & | & 0.000072 & 0.11 & 2.639 & & 0.1345 & 0.0007 & 0.3785 & 0.0048 & 6.9 & 0.097 & 0.1335 & 0.00 & 0.907 \\
\hline 22.1 & 1288 & 910 & 0.09 & 351 & 0.000004 & $\mid \frac{\mid c .01}{0.01}$ & $\frac{2.1515}{3155}$ & 0.029 & $\begin{array}{c}0.1808 \\
0\end{array}$ & $\begin{array}{c}0.0012 \\
0.00004\end{array}$ & $\mid \begin{array}{c}0.4653 \\
0.3159\end{array}$ & $\frac{0.0062}{0.00234}$ & $\frac{11.6344}{4.655 \mid}$ & 0.773 & $\frac{0.1813}{0.1038}$ & 0.00 & 0.893 \\
\hline 23.1 & 660 & 389 & \begin{tabular}{c|c}
0.59 \\
\end{tabular} & 176 & 0.000032 & \begin{tabular}{|l|}
0.05 \\
\end{tabular} & 3.225 & 0.039 & 0.1062 & 0.0007 & 0.3099 & 0.0038 & 4.519 & 0.064 & 0.1058 & 0.0008 & 0.862 \\
\hline & 366 & 665 & 1.82 ] & 92 & 0.000097 & \begin{tabular}{|l|} 
\\
\end{tabular} & 3.412 & 0.052 & 0.1008 & 0.0012 & 0.2956 & 0.0045 & 4.392 & 0.090 & 0.1078 & & 0.750 \\
\hline 2.3 & 年 & 2167 & 0.84: & $\frac{61}{350}$ & 0.0000095 & 0.17 & (3.666) & 48 & 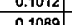 & 0.0009 & $\frac{0.2400}{0300}$ & 0.0035 & 3.7 & .0601 & 1003 & & 0.807 \\
\hline & 0003 & & 0.77 & & 0.00000 & 0.01 & $\frac{3.0464}{3.319}$ & 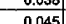 & 108996 & 0.0007 & 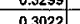 & $\frac{0.0041}{0.0445}$ & & 0771 & $\frac{1116}{10916}$ & 100 & 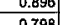 \\
\hline 28. & 656 & 254 & 0.3 & 年 & 0.000032 & $\mid 0.05$ & 年 & 0.03 & $\mid \begin{array}{l}0.736 \\
0.1048\end{array}$ & $\frac{0.010}{0.0007}$ & 0 & 0.00 & $\begin{array}{l}4.3 \\
4.7\end{array}$ & 0.067 & $\mid \frac{0.1471}{0.1066}$ & 0.00 & $\frac{0.19696}{0.869}$ \\
\hline 29. & 2080 & 897 & 0.43 & 555 & 0.000023 & \begin{tabular}{|l|l|}
0.04 \\
\end{tabular} & 3.217 & 0.034 & 0.1060 & 0.0003 & 0.3107 & 0.003 & 4.5 & 0.051 & 0.1057 & 0.0004 & 0.955 \\
\hline & 198 & 136 & 0.69 & 52 & 0.000040 & \begin{tabular}{|l|l|} 
\\
\end{tabular} .06 & 3.281 & 0.053 & 0.0995 & 0.0016 & 0.3062 & 0.0050 & 4.354 & 0.098 & 0.1031 & 0.00 & 0.721 \\
\hline 31. & 2800 & 41 & 0.16 & 68 & & $\leq 0.01$ & 3.277 & .046 & 0.1006 & $0.0011 \mid$ & 0.3053 & 0.004 & 4.253 & 0.077 & 0.1010 & 0.0012 & 0.776 \\
\hline 31. & 228 & 37 & 0.16 & 57 & 0.000121 & \begin{tabular}{|l|l|} 
\\
\end{tabular} .9 & 3.435! & 0.045 & 0.1039 & 0.0010 & 0.2905 & 0.00 & 4.05 & & 0.1022 & 0.0011 & .769 \\
\hline 32. & tour & $61 \%$ & 0,61 & $242 !$ & 0001114 & 0.18 & 3.573 & 445] & 1007 & & 0.2793 & 0.00 & & 597 & 0999 & & .836 \\
\hline 33. & 4999] & $197 \mid$ & 0.39 & 1441] & 000111 & $|0.17|$ & 3.045[ & 0.037 & 0.121 & 3006 & 0.3281 & 0.06 & & & .1115 & 0.06 & 0.903 \\
\hline & 1736] & 767 & 0.44 & 450 & 10024 & \begin{tabular}{|l|}
0.04 \\
\end{tabular} & 3.313 & 0.03 & 0.1034 & & .3018 & & & & 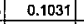 & & \\
\hline 35. & 282 & 159 & 0.56 ] & 80 & 50073 & 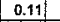 & 3.030 & 0.04 & 0.1108 & 0.0011 & 0.3305 & 0.004 & & & 0.1121 & 0.0011 & 0.830 \\
\hline 36. & 566 & 42 & 0.07 & 134 & 00032 & 0.05 & $3.62=$ & 0.04 & 0.103 & 0.0008 & 0.2760 & 0.003 & 3.8 & 059) & $0.1031\}$ & 0.00 & 0.837 \\
\hline & 135 & 92 & 0.69 & 35 & 00327 & 0.52 & 3.319 & 0.05 & 0.1068 & 0.0018 & 0.30255 & 0.00 & 4.55 & 0.107 & $0.1101\}$ & 0.00 & $\begin{array}{l}0.690 \\
\end{array}$ \\
\hline 38. & 272 & 188 & 0.61 & $-\frac{99}{215}$ & 0.000078 & \begin{tabular}{|l|l|} 
\\
\end{tabular} & 2.350 & 0.02 & 0.1527 & 0.0009 & 0.4251 & 0.00 & 8.88. & & & 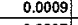 & 0.8977 \\
\hline & 8033) & $\frac{108}{4}$ & 0.13 & 215 & & $\langle 0,07\}$ & 3.215 & 0.0388 & 0.1056 & 0.00065 & 0.31118 & 0.00 & 4.63. & 0.062 & 0.10 & 0.0 & \\
\hline 40.4 & 2017 & 719 & $\begin{array}{l}0.35 \\
0.57\end{array}$ & $\begin{array}{r}66 \\
\end{array}$ & 00002 & $<0.01$ & 2.628 & 0.038 & 0.1283 & 0.0013 & 0 & 0.0 .0 & 8.76 & 0.1 & 0.12 & 0.00 & 0.813 \\
\hline 42.1 & $\frac{0<4}{645}$ & 240 & 0.37 & $\begin{array}{l}1600 \\
163\end{array}$ & Do0037? & & 8.407 & & 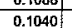 & 007 & 29033 & 0.0 & & & & & \\
\hline 43. & 262 & 103 & 0.41 & \begin{tabular}{|l|}
68 \\
\end{tabular} & , & 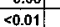 & 年 & 041 & \begin{tabular}{|c|c|}
0.1063 \\
\end{tabular} & 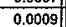 & 0 & 0.00 & & & 0.10 & $\frac{0.00}{0.0}$ & \\
\hline 44 & 799: & 616 & 0.77 & 216 . & 100020 & 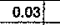 & 3.179 & 0.040 & 0.1050 & 0.0006 & 0.3159 & 0.00 & 4.730 & 0.068 & 0.1086 & 0.0008 & n? \\
\hline ר & 1899 | & 511] & 0.27 & 482 & 0.000002 & 0.00 & 3.530 & 0.038 & D.1.100 & 0.0000 & 0.2833 & 0.002 & 4.02 & 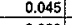 & 0.1030 & 0.0003 & 0.954 \\
\hline - -46.3 & 324 & $\begin{array}{r}94 \\
\end{array}$ & 0.29 & 78 & 0707 & 0. & 3.560] & (4) & 0.1066 & 0.0008 & 0.2808 & 0.00 & 4.1 & 0.0 & 0.10 & & 0.8 \\
\hline 47.1 & $\frac{476}{47655}$ & 4977 & \begin{tabular}{|c|}
1.04 \\
0.50
\end{tabular} & $\begin{array}{l}\frac{138}{505} \\
505\end{array}$ & 0.0000035 & 0.05 & 2.9566 & & 0.1124 & & \begin{tabular}{|c|c|c|c|c|} 
\\
\end{tabular} & 0.00 & 5.3 & & 0.1 & & 0.876 \\
\hline $\mid$ & 250 & \begin{tabular}{rl|}
886 \\
82
\end{tabular} & 0.33 & \begin{tabular}{r|}
$565 \mid$ \\
67
\end{tabular} & $\begin{array}{r}0.0600032 \\
0.000088\end{array}$ & $\begin{array}{l}0.05 \\
0.11\end{array}$ & $\begin{array}{l}3.0 \\
3.1\end{array}$ & & $\begin{array}{l}0.14141 \\
0.1066\end{array}$ & & $\begin{array}{l}0.3326 \\
0.3140\end{array}$ & 0.00 & 5.2 & & & & 0.942 \\
\hline 50.1 & 2588 & \begin{tabular}{|l|l|}
124 \\
\end{tabular} & 0.48 & 70 & 0.000028 & $0.04 \mid$ & \begin{tabular}{|c|}
3.168 \\
\end{tabular} & & 0.0000 & 0.00009 & 0.3155 & 0.0 & & & & & 0.04 \\
\hline 51.1 & 720] & 350 ] & 0.49 | & 184 & & $<0.01$ & 3.364 & 440 & 0.1031 & 0.0008 & 0.2973 & 0.00 & 4.230 & 0.6 & 0.1032 & 0.00 & 0.847 \\
\hline 52. & 305! & 139 & & 82 & 00097 & & 3.18 & |344. & 0.1086 & 0.0011 & 0.3138 & & 4.5 & 0.8 & 0.10 & 0.0 & 0. \\
\hline 53 & 612 & 244 & $0.40]$ & 174 & B0126] & 0. & 3.029 & 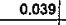 & 0.1125 & 000080 & 0.32 & & & & & & \\
\hline 55 & 5377 & 25 & (4B). & $\frac{132}{353}$ & 0015 & 0.02 & 3.502 & 0. & 0.1056 & 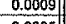 & 0.2 & & 4.1. & - & & & 0.786 \\
\hline ב3, & $\frac{1277}{51483}$ & 374 & . 0.30 & 353. & & 0.07 & 3.111 & & 0.1122 & & & & & & & 0.0 & 0.9 \\
\hline 57. & $\mid$ & $\frac{24 / 1}{105}$ & 0.22 & $\frac{0.44}{54}$ & 00051 & $\frac{50.01}{0.08}$ & $\frac{3.243}{3.139}$ & & -0.1029 & & & & & 0.00 & & 0.0 & \\
\hline 58. & 614 & 60 & 0.10 & 168 & & 0.11 & 3 & & 0.1090 & 0.0006 & 0.3151 & 0.00 & & 3 & & 0.00 & 0.884 \\
\hline 59. & 137. & 48 & 0.35 & 36 & & 0.12 & 3.2 & & & & & & & & & & 0.721 \\
\hline 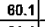 & 260 & 172 & 0.86 & 95 & & & 2.349 & & 0.1841 & & & & & & 10:3 & & \\
\hline 61. & 329 & 108 & $\begin{array}{l}0.33 \\
\end{array}$ & $\begin{array}{l}112 \\
\end{array}$ & & & 2.520 & & 0.1560 & 0.0 & 0.3966 & & 8.5 & 0.066 & $0.1555 \mid$ & & \\
\hline 62. & 202 & 111 & 0.55 & 54 & & 0.161 & \begin{tabular}{|c|}
3.244 \\
\end{tabular} & & 0.1076 & 0.0 & 0.3 & 0.0 & 4.02 & 0.0 & 0.10002 & 0.0011 & 0.795 \\
\hline 64 & \begin{tabular}{|l|l|}
2187 & \\
9367
\end{tabular} & \begin{tabular}{l|l|l|}
1114 \\
345
\end{tabular} & $\begin{array}{l}0.51 \\
0.37\end{array}$ & $\begin{array}{ll}592 \\
261\end{array}$ & & 0.07 & \begin{tabular}{|c|}
3.174 \\
3083
\end{tabular} & & 0.1 & 0.0003 & & & 1 & n & 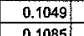 & 00 & 0.5 \\
\hline$\frac{64.1}{65.1}$ & $\mid$ & $\frac{345}{47}$ & $|0.37|$ & $\mid \frac{261}{127}$ & & $\mid$ & $\mid$\begin{tabular}{|c|c|c|}
3.083 \\
3442
\end{tabular} & & $\frac{0.1089}{0.1040}$ & $007 \|$ & & & $\begin{array}{l}4.852 \\
4.965\end{array}$ & 9) & 0.1 & $0.0005 \mid$ & 0.923 \\
\hline$\frac{65 .}{67 .}$ & $\frac{3048}{778}$ & $\frac{4 !}{40}$ & \begin{tabular}{|c|}
0.09 \\
0.05
\end{tabular} & 年2 & $\begin{array}{c}0.000012 \\
0.000018\end{array}$ & $\begin{array}{l}0.02 \\
0.03\end{array}$ & \begin{tabular}{|}
3.442 \\
3.300
\end{tabular} \mid & 381 & $\frac{0.1040}{0.1088}$ & o.000007 & 0.36 & & 4.1956 & & 0.1 & & \\
\hline 68. & & 376 & 0.43 & 221 & & $<0.0$ & 3.3. & & $\frac{1.01000}{0.1059}$ & & 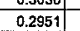 & $\frac{0.00}{0.00}$ & & & & & \\
\hline 69. & 489 ? & 492 & 1.01 & 124 & $t$ & 0.07 & 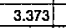 & & & & 0.2 & & & & & & \\
\hline 70.1 & 1398 & 521 & 0.37 & 354 & & 0.02 & 3.3 & & & & & & & & & & \\
\hline 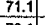 & 882 & 493 & 0.56 & 239 & & 0.06 & 3.171 & & & & 0.31 & & 4.7 & & & & \\
\hline & 447 & 200 & 0.45 & 96 & & 0.04 & $\begin{array}{l}4.019 \\
\end{array}$ & 0.048 & & & 0.2 & & & & & & \\
\hline 73.1 & 184 & $90 \mid$ & $\overline{0.49}$ & 1.t & & 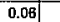 & & & & & & & & & & & \\
\hline 74. & 1867? & 1312 & 070 & 404 & & 0.02 & 3.968 & 0.1 & 0.0 & & 0.25 & & 3.1 & & & & \\
\hline & 259 & 136 & 1.52 & 64 & & 0.1 & 3.4 & 0. & & & & & & & & & \\
\hline 76.1 & 254 & 65 & 0.26 & 63 & & 0.1 & 3.484 & & & & 0.2866 & & 4.168 & & & & \\
\hline 77 & 337] & 184 & 0.54 & 86] & 0.00 & 0.03 & 3.363 & 0.4 & & & 0.200 & & 4.420 & & & & \\
\hline 78,1 & 16900] & 291 & 0.17 & 489. & 0.000020 & 0.03 & 2.969 & 0.0 & & & 0.336 & & 5.161 & & & & \\
\hline 79.1 & 432 & 145 & 0.34 & 127 & $\cdot$ & 00.01 & 3.074 & 0.038 & 0.1102 & 0.0008 & 0.3255] & 0.0040 & 4.970 & 0.077 & 0.1107 & 0.0008 & 0.860 \\
\hline & & & & & & & & & & & & & & & & & \\
\hline & & & ntiog & & & & & & & & & & & & & & \\
\hline & & & & & & & & & & & & & & & & & \\
\hline & & & & & & & & & & & & & & & & & \\
\hline & & $60 \%$ & Anol & he percent & th & hat I & maman $\mathrm{Pb}$ & & & & & & & & & & \\
\hline & & & & & 45 & & & & & & & & & & & & \\
\hline & & & & & & & & & & & & & & & & & \\
\hline
\end{tabular}


TABLE 3F.-Summary of SHRIMP U-Pb zircon results for sample 39PL02.

\begin{tabular}{|c|c|c|c|c|c|c|c|c|c|c|c|c|c|c|c|c|c|c|c|c|c|c|}
\hline \multirow[b]{2}{*}{ Grain. } & \multirow[b]{2}{*}{ U } & & & & & & & Total F & atios & & & & Radiogenic & Ratios & & & & & & e (Ma) & & \\
\hline & & Th & $T h / \mathrm{U}$ & $\mathrm{Pb}^{*}$ & ${ }^{204} \mathrm{~Pb} /$ & $f_{206}$ & ${ }^{238} \mathrm{UI}$ & & ${ }^{207} \mathrm{~Pb} /$ & & ${ }^{206} \mathrm{~Pb} /$ & & ${ }^{207} \mathrm{~Pb} /$ & & ${ }^{207} \mathrm{~Pb} /$ & & & ${ }^{206} \mathrm{~Pb} /$ & & ${ }^{207} \mathrm{~Pb} /$ & & $\%$ \\
\hline spot & (ppm) & (ppm) & & $(\mathrm{ppm})$ & ${ }^{208} \mathrm{~Pb}$ & $\%$ & ${ }^{206} \mathrm{~Pb}$ & \pm & ${ }^{206} \mathrm{~Pb}$ & \pm & ${ }^{238} \mathrm{U}$ & \pm & ${ }^{235} \mathrm{U}$ & \pm & ${ }^{200} \mathrm{~Pb}$ & \pm & $\rho$ & ${ }^{238} \mathrm{U}$ & \pm & ${ }^{206} \mathrm{~Pb}$ & \pm & Disc \\
\hline & & & & & & & & & & & & & & & & & & & & & & \\
\hline 1.1 & 536 & 322 & 0.60 & 145 & - & $<0.01$ & 3.166 & 0.034 & 0.1089 & 0.0004 & 0.3159 & 0.0034 & 4.745 & 0.054 & 0.1089 & 0.0004 & 0.936 & 1770 & 17 & 1782 & 7 & 1 \\
\hline 2.1 & 136 & 90 & 0.66 & 34 & 0.000053 & 0.08 & 3.458 & 0.044 & 0.1026 & 0.0009 & 0.2889 & 0.0037 & 4.059 & 0,066 & 0.1019 & 0.0010 & 0.780 & 1636 & 18 & 1659 & 19 & $t$ \\
\hline 3.1 & 187 & 77 & 0.41 & 50 & 0.000029 & 0.04 & 3.231 & 0.038 & 0.1057 & 0.0008 & 0.3094 & 0.0037 & 4.492 & 0.063 & 0.1053 & 0.0008 & 0.842 & 1738 & 18 & 1720 & 14 & -1 \\
\hline 4.1 & 335 & 168 & 0.50 & 90 & 0.000047 & 0.07 & 3.181 & 0.035 & 0.1059 & 0.0006 & 0.3141 & 0.0035 & 4.560 & 0.059 & 0.1053 & 0.0007 & 0.852 & 1761 & 17 & 1720 & 12 & -2 \\
\hline 5.1 & 652 & 318 & 0.49 & 181 & 0.000008 & 0.01 & 3.102 & 0.033 & 0.1087 & 0.0004 & 0.3224 & 0.0034 & 4.825 & 0.054 & 0.1085 & 0.0004 & 0.840 & 1801 & 17 & 1775 & 7 & -1 \\
\hline 6.1 & 363 & 61 & 0.17 & 103 & 0.000023 & 0.04 & 3.030 & 0.033 & 0.1099 & 0.0006 & 0.3301 & 0.0036 & 5.009 & 0.061 & 0.1100 & 0.0006 & 0.907 & 1839 & 18 & 1800 & 9 & -2 \\
\hline 7.1 & 3212 & 457 & 0.14 & 756 & 0.000034 & 0.05 & 3.650 & 0.038 & 0.0982 & 0.0002 & 0.2738 & 0.0028 & 3.689 & 0.039 & 0.0977 & 0.0002 & 0.973 & 1560 & 14 & 1581 & 5 & 1 \\
\hline 8.1 & 142 & 49. & 0.34 & 38 & - & $<0.01$ & 3.219 & 0.039 & 0.1052 & 0.0009 & 0.3107 & 0.0038 & \begin{tabular}{l|l}
4.511 \\
\end{tabular} & $\begin{array}{l}0,067 \\
\end{array}$ & 0.1053 & 0.0009 & 0.828 & 1744 & 19 & 1719 & 15 & -1 \\
\hline 9.1 & 411 & 76 & 0.18 & 116 & - & $<0.01$ & 3.060 & 0.033 & 0.1097 & 0.0005 & 0.3269 & 0.0036 & 4.954 & 0.059 & 0.1099 & 0.0005 & 0.910 & 1823 & 17 & 1798 & 9 & -1 \\
\hline 10.1 & 589 & 144 & 0.24 & 260 & 0.000007 & 0.01 & 1.947 & 0.021 & 0.1646 & 0.0007 & 0.5137 & 0.0056 & 11.649 & 0.136 & 0.1645 & 0.0007 & 0.937 & 2672 & 24 & 2502 & 7 & -7 \\
\hline 11.1 & 350 & 81 & 0.23 & 92 & - & $<0.01$ & 3.283 & 0.037 & 0.1053 & 0.0006 & 0.3047 & 0.0035 & $\begin{array}{l}4.425 \\
\end{array}$ & $\begin{array}{l}0.056 \\
\end{array}$ & 0.1054 & 0.0006 & 0.904 & 1714 & 17 & 1721 & 10 & 0 \\
\hline 12.1 & 483 & 143 & 0.30 & 129 & 0.000014 & $\begin{array}{l}0.02 \\
\end{array}$ & $\begin{array}{ll}3.216 \\
\end{array}$ & 0,035 & 0.1060 & 0,0006 & 0.3109 & 0.0034 & 4.536 & 0.057 & 0.1058 & 0.0006 & 0.878 & 1745 & 17 & 1729 & 11 & -1 \\
\hline 13.1 & 768 & 154 & 0.20 & 249 & 0.000015 & 0.02 & 2.651 & 0.028 & 0.1230 & 0.0004 & 0.3771 & 0.0040 & \begin{tabular}{|l|l|}
6.383 \\
\end{tabular} & 0.071 & 0.1228 & 0.0004 & 0.952 & 2063 & 19 & 1997 & 6 & -3 \\
\hline 14.1 & 482 & 160 & $\begin{array}{ll}0.33 \\
\end{array}$ & 134 & 0.000002 & 0.00 & 3.089 & 0.035 & 0.1056 & 0.0005 & 0.3237 & 0.0036 & 4.712 & 0.057 & 0.1056 & 0.0005 & 0.923 & 1808 & 18 & 1724 & 9 & -5 \\
\hline 15.1 & 329 & 90 & 0.27 & 85 & - & $<0.01$ & \begin{tabular}{|c|}
3.333 \\
\end{tabular} & 0.037 & $\begin{array}{ll}0.1053 \\
\end{array}$ & 0.0006 & 0.3001 & 0.0034 & 4.368 & 0.055 & 0.1056 & 0.0006 & 0.884 & 1692 & 17 & 1724 & 11 & 2 \\
\hline 16,1 & 510 & 115 & 0.22 & 124 & 0.000021 & 0.03 & 3.546 & 0.038 & 0.1008 & 0.0005 & 0.2819 & 0.0031 & 3.905 & 0.047 & 0.1005 & 0.0005 & 0.910 & 1601 & 15 & 1633 & g & 2 \\
\hline 17.1 & 246 & 158 & 0.64 & $\begin{array}{ll}67 \\
\end{array}$ & - & \begin{tabular}{|c|} 
\\
\end{tabular} & 3.160 & 0.036 & 0.1050 & 0.0007 & 0.3165 & 0.0037 & 4.585 & 0.061 & 0.1051 & 0.0007 & 0.871 & 1772 & 18 & 1716 & 12 & -3 \\
\hline 18.1 & 279 & 139 & 0.50 & 77 & 0.000090 & \begin{tabular}{|l|l|}
0.14 \\
\end{tabular} & 3.115 & 0.034 & 0.1101 & 0.0005 & 0.3205 & 0.0035 & 4.810 & 0.061 & 0.1088 & 0.0007 & 0.864 & 1792 & 17 & 1780 & 12 & -1 \\
\hline 19.1 & 314 & 260 & 0.83 & 73 & - & $<0.01$ & 3.692 & 0.040 & 0.1029 & 0.0005 & 0.2709 & 0.0029 & \begin{tabular}{|l|l|}
3.847 \\
\end{tabular} & $\begin{array}{l}0.046 \\
\end{array}$ & 0.1030 & 0.0005 & 0.910 & 1545 & 15 & 1679 & 9 & 8 \\
\hline 20.1 & 524 & 101 & 0.19 & 133 & $=$ & $<0.01$ & $\begin{array}{l}3.385 \\
\end{array}$ & $\begin{array}{l}0.036 \\
\end{array}$ & 0.1024 & 0.0004 & 0.2955 & 0.0031 & 4.171 & 0.047 & 0.1024 & 0.0004 & 0.934 & 1669 & 16 & 1668 & 8 & 0 \\
\hline 21.1 & 323 & 47 & 0.15 & 79 & 0.000026 & 0.04 & $\begin{array}{l}3.525 \\
\end{array}$ & 0.038 & 0.1022 & 0.0005 & 0.2836 & 0.0031 & \begin{tabular}{|l|}
3.983 \\
\end{tabular} & 0.049 & 0.1019 & 0.0006 & 0.883 & 1609 & 16 & 1659 & 11 & 3 \\
\hline 22.1 & 261 & 112 & 0.43 & 66 & 0.000109 & $\begin{array}{l}0.17 \\
\end{array}$ & 3.391 & 0.040 & 0.1036 & 0.0006 & 0.2944 & 0.0034 & 4.143 & 0.058 & 0.1021 & 0.0008 & 0.830 & $\begin{array}{l}1663 \\
\end{array}$ & 17 & 1662 & 15 & 0 \\
\hline 23.1 & 99 & 36 & 0.37 & 40 & 0.000031 & 0.04 & 2.094 & 0.027 & 0.1691 & 0.0011 & 0.4773 & 0.0060 & 11.101 & 0.158 & 0.1687 & 0.0011 & 0.891 & 2516 & 26 & 2545 & 11 & 1 \\
\hline 24.1 & 112 & 53 & 0.47 & 30 & 0.000183 & 0.29 & 3.223 & 0.044 & 0.1122 & 0.0011 & 0.3094 & 0.0043 & 4.678 & 0.096 & 0.1097 & 0.0017 & 0.675 & 1738 & 21 & 1794 & 27 & 3 \\
\hline 25.1 & 458 & 30 & 0.06 & 120 & 0.000037 & 0.06 & 3.279 & 0.035 & 0.1044 & 0.0005 & 0.3048 & $\begin{array}{l}0.0033 \\
\end{array}$ & 4.366 & 0.052 & $\begin{array}{l}0.1039 \\
\end{array}$ & 0.0005 & 0.905 & $\begin{array}{l}1715 \\
\end{array}$ & 16 & 1695 & 9 & -1 \\
\hline 26.1 & 2072 & 1443 & 0.70 & 556 & 0.000003 & $<0.01$ & 3.207 & 0.033 & $\begin{array}{l}0.1033 \\
\end{array}$ & 0.0002 & 0.3118 & 0.0032 & 4.439 & 0.047 & 0.1033 & 0.0002 & 0.974 & 1749 & 16 & 1684 & 4 & -4 \\
\hline 27.1 & 227 & 56 & 0.25 & 62 & 0.000018 & \begin{tabular}{|l|l}
0.03 \\
\end{tabular} & \begin{tabular}{|l|l|}
3.124 \\
\end{tabular} & 0.036 & 0.1096 & 0.0007 & 0.3200 & 0.0037 & 4.825 & 0.065 & 0.1094 & 0.0008 & 0.856 & 1790 & 18 & 1789 & 13 & 0 \\
\hline 28.1 & 127 & 57 & 0.45 & 37 & 0.000015 & 0.02 & 2.973 & 0.037 & 0.1088 & 0.0009 & 0.3363 & 0.0042 & 5.038 & $\begin{array}{l}0.079 \\
\end{array}$ & 0.1086 & 0.0011 & 0.787 & 1869 & 20 & 1777 & 18 & -5 \\
\hline 29.1 & 228 & 163 & 0.71 & 96 & 0.000036 & 0.05 & 2.043 & 0.024 & 0.1605 & 0.0008 & 0,4892 & 0.0056 & \begin{tabular}{l|l}
10.797 \\
\end{tabular} & 0.135 & 0.1601 & 0.0008 & 0.918 & 2567 & 24 & 2456 & 8 & -5 \\
\hline 30.1 & \begin{tabular}{|l|l|}
463 \\
\end{tabular} & 204 & 0.44 & 128 & 0.000070 & 0.11 & 3.118 & 0.034 & 0.1084 & 0.0005 & 0.3209 & 0.0035 & 4.812 & 0.057 & 0.1088 & 0.0005 & 0.923 & 1794 & 18 & 1779 & 8 & -1 \\
\hline 31.1 & 230 & 193 & 0.84 & 59 & 0.000006 & 0.01 & \begin{tabular}{|l|l|}
3.327 \\
\end{tabular} & 0.040 & 0.1059 & 0.0007 & 0.3005 & 0.0036 & 4.386 & 0.060 & 0.1059 & 0.0007 & 0.875 & 1694 & 18 & 1729 & 12 & 2 \\
\hline 32.1 & 295 & 344 & 1.16 & 61 & 0.000033 & $\begin{array}{ll}0.05 \\
\end{array}$ & 4.181 & 0.047 & 0.0897 & 0.0006 & 0.2390 & 0.0027 & 2.940 & $\begin{array}{l}0.041 \\
\end{array}$ & 0.0892 & 0.0007 & 0.817 & 1382 & 14 & 1409 & 15 & 2 \\
\hline 33.1 & 788 & 62 & 0.08 & 212 & - & $<0.01$ & \begin{tabular}{|l|l|}
3.194 \\
\end{tabular} & $\begin{array}{l}0.034 \\
\end{array}$ & 0.1097 & 0,0004 & 0.3131 & 0.0033 & $\begin{array}{l}4.736 \\
\end{array}$ & 0.053 & 0.1097 & 0.0004 & 0.953 & 1756 & 16 & 1794 & 6 & 2 \\
\hline 34.1 & 274 & 218 & 0.80 & 74 & 0.000014 & 0.02 & 3.169 & 0.036 & 0.1089 & 0.0006 & 0.3155 & 0.0036 & 4.730 & 0.060 & 0.1087 & 0.0006 & 0.888 & 1768 & 17 & 1778 & 11 & 1 \\
\hline 35.1 & 214 & 85 & 0.40 & 69 & 0.000056 & 0.08 & 2.678 & 0.031 & 0.1251 & 0.0007 & 0.3731 & 0.0043 & 6.399 & 0.087 & 0.1244 & 0.0009 & \begin{tabular}{|c|c|}
0.861 \\
\end{tabular} & 2044 & 20 & 2020 & 12 & -1 \\
\hline 36.1 & 279 & 93 & $\begin{array}{l}0.33 \\
\end{array}$ & 79 & 0.000027 & $\begin{array}{ll}0.04 \\
\end{array}$ & 3.355 & 0.038 & 0.1069 & 0.0006 & 0.2979 & 0.0034 & 4.376 & $\begin{array}{l}0.057 \\
\end{array}$ & 0.1065 & 0.0007 & 0.868 & 1681 & 17 & 1741 & 12 & 3 \\
\hline 37.1 & 847 & 340 & 0.40 & 2266 & 0.000298 & 0.46 & $\begin{array}{l}3.223 \\
\end{array}$ & \begin{tabular}{|l|l|}
0.034 \\
\end{tabular} & 0.1175 & 0.0009 & 0.3089 & 0.0033 & 4.834 & $\begin{array}{ll}0.072 \\
\end{array}$ & 0.1135 & 0.0012 & 0.720 & 1735 & 16 & 1856 & 19 & 7 \\
\hline 38.1 & 905 & 640 & 0.71 & 234 & 0.000021 & 0.03 & 3.322 & 0.035 & 0.1064 & 0.0004 & 0.3009 & 0.0032 & 4.404 & $\begin{array}{l}0.049 \\
\end{array}$ & 0.1061 & 0.0004 & 0.944 & 1696 & 16 & 1734 & 7 & 2 \\
\hline 39.1 & 940 & 383 & 0.41 & 259 & 0.000018 & 0.03 & 3.122 & 0.033 & 0.1056 & 0.0004 & 0.3202 & 0.0034 & 4.650 & 0.052 & 0.1053 & 0.0004 & 0.948 & 1791 & 16 & 1720 & 7. & -4 \\
\hline 40.1 & 325 & 155 & 0.48 & 80 & 0.000043 & 0.07 & 3.493 & 0.039 & 0.1026 & 0.0006 & 0.2861 & 0.0032 & 4.023 & 0.052 & 0.1020 & 0.0007 & 0.854 & 1622 & 16 & 1661 & 13 & 2 \\
\hline $\begin{array}{l}41.1 \\
\end{array}$ & 89 & 61 & 0.69 & 23 & 0.000002 & 0.00 & $\begin{array}{ll}3.296 \\
\end{array}$ & $\begin{array}{l}0.046 \\
\end{array}$ & 0.1015 & 0.0011 & 0.3034 & 0.0042 & 4.243 & 0.081 & 0.1014 & 0.0013 & 0.727 & 1708 & 21 & 1651 & 24 & -3 \\
\hline 42.1 & 302 & 199 & 0.66 & 78 & 0.000032 & \begin{tabular}{l|}
0.05 \\
\end{tabular} & \begin{tabular}{|l|}
3.317 \\
\end{tabular} & 0.038 & 0.1046 & 0.0006 & 0.3014 & 0.0034 & 4.329 & $\begin{array}{l}0.056 \\
\end{array}$ & 0.1042 & 0.0006 & 0.878 & 1698 & 17 & 1700 & 11 & 0 \\
\hline 43.1 & 140 & 33 & 0.23 & 38 & 0.000059 & 0.09 & 3.208 & 0.040 & 0.1097 & 0.0009 & 0.3114 & 0.0039 & 4.675 & 0.077 & 0.1089 & 0.0012 & 0.761 & 1748 & 19 & 1781 & 19 & 2 \\
\hline 44.1 & 131 & 60 & 0.46 & \begin{tabular}{l|l}
33 \\
\end{tabular} & 0.000080 & 0.13 & 3.352 & 0.045 & 0.1056 & 0.0009 & 0.2980 & 0.0040 & 4.293 & 0.075 & 0.1045 & 0.0012 & 0.767 & 1681 & 20 & 1706 & 21] & 1 \\
\hline \begin{tabular}{l|l|}
45.1 \\
\end{tabular} & 267 & 78 & 0.29 & $\begin{array}{l}79 \\
\end{array}$ & 0.000022 & 0.03 & \begin{tabular}{|l|}
2.920 \\
\end{tabular} & $\begin{array}{l}0.033 \\
\end{array}$ & 0.1144 & 0.0007 & 0.3424 & 0.0039 & \begin{tabular}{|l|l}
5.384 \\
\end{tabular} & 0.070 & 0.1141 & 0.0007 & 0.876 & 1898 & 19 & 1865 & 11 & -2 \\
\hline 46.1 & 181 & 79 & 0.44 & 52 & 0.000014 & 0.02 & 2.985 & 0.037 & 0.1124 & 0.0008 & 0.3350 & 0.0042 & \begin{tabular}{|l|l|}
5.183 \\
\end{tabular} & $\begin{array}{l}0.076 \\
\end{array}$ & 0.1122 & 0.0009 & 0.852 & 1862 & 20 & 1836 & 14 & -1 \\
\hline 47.1 & 456 & 70 & 0.15 & 117 & 0.000021 & 0.03 & \begin{tabular}{|l|}
3.362 \\
\end{tabular} & 0.038 & 0.1061 & 0.0005 & 0.2973 & 0.0033 & 4.339 & \begin{tabular}{ll|l}
0.054 & \\
\end{tabular} & 0.1058 & 0.0006 & 0.897 & 1678 & 17 & \begin{tabular}{ll|}
1729 \\
\end{tabular} & 10 & 3 \\
\hline 48.1 & 466 & 235 & 0.51 & 115 & 0.000100 & 0.16 & 3.481 & 0.038 & 0.1030 & 0.0005 & 0.2863 & 0.0031 & 3.950 & 0.050 & 0.1001 & 0.0006 & 0.864 & 1623 & 17 & 1625 & 12 & 0 \\
\hline 49.1 & 94 & 59 & 0.63 & 23 & 0.000177 & 0.28 & 3.563 & 0.049 & 0.1041 & 0.0012 & 0.2787 & 0.0038 & 3.784 & 0.074 & 0.0985 & 0.0014 & 0.699 & 1585 & 21 & 1595 & 26 & 1 \\
\hline 50.1 & 199 & 84 & 0.42 & 51 & 0.000006 & 0.01 & 3.361 & 0.042 & 0.1119 & 0.0011 & 0.2975 & 0.0037 & 4.586 & 0.074 & 0.1118 & 0.0011 & 0.780 & 1679 & 19 & 1829 & 18 & 8 \\
\hline 51.1 & 264 & 122 & 0.46 & 73 & 0.000098 & 0.15 & 3.112 & 0.038 & 0.1089 & 0.0007 & 0.3209 & 0.0039 & 4.760 & 0.070 & 0.1076 & 0.0009 & 0.824 & 1794 & 19 & 1759 & 15 & -2 \\
\hline 52.1 & 292 & 77 & 0.26 & 79 & 0.000064 & 0.10 & 3.183 & 0.037 & 0.1075 & 0.0007 & 0.3139 & 0.0036 & 4.615 & 0.064 & 0.1066 & 0.0008 & 0.829 & 1760 & 18 & 1743 & 14 & -1 \\
\hline 53.1 & 76 & 69 & 0.90 & 22 & 0.000076 & 0.12 & 2.987 & 0.048 & 0.1113 & 0.0013 & 0.3344 & 0.0054 & 5.086 & 0.109 & 0.1103 & 0.0016 & 0.751 & 1860 & 26 & 1804 & 26 & -3 \\
\hline 54.1 & 319 & 34 & 0.11 & 66 & 0.000039 & 0.06 & 4.119 & 0.048 & 0.0956 & 0.0007 & 0.2426 & $\begin{array}{l}0.0028 \\
\end{array}$ & 3.178 & 0.044 & 0.0950 & 0.0007 & 0.850 & 1400 & 15 & 1528 & 14 & 8 \\
\hline 55.1 & 193 & 83 & 0.43 & 52 & 0.000147 & 0.23 & 3.186 & 0.038 & 0.1084 & 0.0008 & 0.3133 & 0.0037 & 4.620 & 0.066 & 0.1070 & 0.0008 & 0.836 & 1757 & 19 & 1748 & 14 & 0 \\
\hline 56.1 & 220 & 120 & 0.55 & 67 & 0.000044 & 0.07 & 2.840 & \begin{tabular}{l|l|l}
0.033 \\
\end{tabular} & 0.1194 & 0.0008 & 0.3518 & 0.0041 & 5.763 & 0.079 & 0.1188 & 0.0008 & 0.857 & 1943 & 20 & 1938 & 13 & 0 \\
\hline 57.1 & 744 & 22 & 0.03 & 194 & 0.000013 & 0.02 & 3.303 & 0.036 & 0.1053 & 0.0004 & 0.3027 & 0.0033 & 4.388 & 0.051 & 0.1051 & 0.0004 & 0.933 & 1705 & 16 & 1717 & 8 & 1 \\
\hline 58.1 & 150 & 86 & 0.57 & 60 & - & $<0.01$ & 2.155 & 0.027 & 0.1652 & 0.0010 & 0.4642 & 0.0058 & 10.587 & 0.147 & 0.1654 & 0.0010 & 0.891 & 2458 & 25 & 2512 & 11 & 2 \\
\hline 59.1 & 99 & 50 & 0.50 & 26 & 0.000066 & 0.10 & 3.273 & 0.046 & 0.1063 & 0.0012 & 0.3052 & 0.0043 & 4.436 & 0.083 & 0.1054 & 0.0013 & 0.743 & 1717 & 21 & 1722 & 23 & 0 \\
\hline 60.1 & 428 & 105 & 0.25 & 112 & - & $<0.01$ & 3.287 & $\begin{array}{ll}0.037 \\
\end{array}$ & 0.1059 & 0.0006 & 0.3043 & 0.0034 & 4.446 & 0.055 & 0.1060 & 0.0006 & 0.898 & 1713 & 17 & 1731 & 10 & 1 \\
\hline 61.1 & 235 & 51 & 0.22 & 58 & 0.000120 & 0.19 & 3.585 & 0.042 & 0.0995 & 0.0007 & 0.2784 & \begin{tabular}{ll|}
0.0033 \\
\end{tabular} & 3.756 & 0.059 & 0.0978 & 0.0010 & 0.756 & 1583 & 17 & 1583 & 19 & 0. \\
\hline & & & & & & & & & & & & & & & & & & & & & & \\
\hline & & & & & & & & & & & & & & & & & & & & & & \\
\hline Notes : & & 1. Uncert & ainties $\mathrm{g}$ & given at & he one $\sigma$ leve & & & & & & & & & & & & & & & & & \\
\hline & & 2. $f_{200} \% d$ & lenotes $t$ & the perc & entage of ${ }^{206} \mathrm{P}$ & $b$ that $i$ & common & & & & & & & & & & & & & & & \\
\hline & & 3. Correct & tion for 0 & common & $\mathrm{Pb}$ made usir & ing the $m$ & easured & ${ }^{04} \mathrm{~Pb} /{ }^{\circ 00}$ & & & & & & & & & & & & & & \\
\hline & & 4. For $\%$ & Disc, $0 \%$ & o denote & s a concordar & int analys & & & & & & & & & & & & & & & & \\
\hline
\end{tabular}


TABLE 3G.-Summary of SHRIMP U-Pb zircon results for sample 23PL92.

\begin{tabular}{|c|c|c|c|c|c|c|c|c|c|c|c|c|c|c|c|c|c|c|c|c|c|c|}
\hline & & & & & & & & Total R & atios & & & & adiogeni & Ratios & & & & & & e (Ma) & & \\
\hline Grain. & U & Th & $\mathrm{Th} / \mathrm{U}$ & $\mathrm{Pb}^{*}$ & ${ }^{204} \mathrm{~Pb} /$ & $f_{200}$ & ${ }^{238} \mathrm{U} /$ & & ${ }^{208} \mathrm{~Pb} /$ & & ${ }^{206} \mathrm{~Pb} /$ & & ${ }^{207} \mathrm{~Pb} /$ & & ${ }^{205} \mathrm{~Pb} /$ & & & ${ }^{206} \mathrm{~Pb} /$ & & ${ }^{207} \mathrm{~Pb} /$ & & $\%$ \\
\hline spot & (ppm) & (ppm) & & (ppm) & ${ }^{208} \mathrm{~Pb}$ & $\%$ & ${ }^{206} \mathrm{~Pb}$ & \pm & ${ }^{266} \mathrm{~Pb}$ & \pm & ${ }^{238} \mathrm{U}$ & \pm & ${ }^{235} \mathrm{U}$ & \pm & ${ }^{208} \mathrm{~Pb}$ & \pm & $\rho$ & ${ }^{238 \mathrm{U}}$ & \pm & ${ }^{206} \mathrm{pb}$ & \pm & Disc \\
\hline & & & & & & & & & & & & & & & & & & & & & & \\
\hline 1.1 & 488 & 126 & 0.26 & 120.1 & 0.000169 & \begin{tabular}{|l|}
0.29 \\
\end{tabular} & 3.488 & 0.038 & 0.1039 & 0.0005 & 0.2859 & 0.0031 & 4.002 & 0.052 & 0.1015 & 0.0007 & 0.838 & 1621 & 16 & 1653 & 13 & 2 \\
\hline 2.1 & 868 & 360 & 0.41 & 215.8 & 0.000031 & \begin{tabular}{|l|}
0.05 \\
\end{tabular} & 3.454 & 0.036 & $\begin{array}{l}0.1067 \\
\end{array}$ & 0.0003 & 0.2894 & 0.0030 & 4.241 & 0.046 & 0.1063 & 0.0003 & 0.957 & 1639 & 15 & 1737 & 6 & 6 \\
\hline 3.1 & 649 & 147 & 0.23 & 167.9 & 0.000030 & 0.05 & 3.319 & 0.036 & 0.1152 & 0.0004 & 0.3012 & 0.0033 & 4.768 & 0.054 & 0.1148 & 0.0004 & 0.953 & 1697 & 16 & 1877 & 6 & 10 \\
\hline 4.1 & 183 & 101 & 0.55 & $\begin{array}{ll}46.2 \\
\end{array}$ & 0.000166 & \begin{tabular}{|l|}
0.28 \\
\end{tabular} & 3.400 & 0.040 & 0.1065 & 0.0007 & 0.2933 & 0.0035 & 4.216 & 0.063 & 0.1043 & 0.0009 & 0.798 & 1658 & 17 & 1701 & 17 & 3 \\
\hline 5.1 & 300 & 85 & 0.28 & 78.2 & 0.000083 & 0.14 & 3.297 & 0.037 & 0.1049 & 0.0006 & 0.3028 & 0.0034 & 4.331 & 0.057 & 0.1037 & 0.0007 & 0.866 & 1705 & 17 & 1692 & 12 & -1 \\
\hline 6.1 & 904 & 313 & 0.35 & $\begin{array}{ll}222.2 \\
\end{array}$ & 0.000043 & 0.07 & 3.493 & 0.037 & 0.1045 & 0.0003 & 0.2860 & 0.0030 & 4.098 & 0.046 & 0.1039 & 0.0003 & \begin{tabular}{|l|l|}
0.954 \\
\end{tabular} & 1622 & 15 & 1695 & 6 & 4 \\
\hline 7.1 & 2202 & 40 & 0.02 & 248.2 & 0.000874 & 1.48 & 7.624 & 0.079 & 0.1125 & 0.0006 & 0.1292 & 0.0013 & 1.790 & 0.038 & 0.1004 & 0.0019 & \begin{tabular}{|l|l}
0.484 \\
\end{tabular} & 783 & 8 & 1632 & 35 & 52 \\
\hline 8.1 & 697 & 271 & 0.39 & 74.6 & 0.000660 & 1.14 & $\begin{array}{l}8.019 \\
\end{array}$ & 0.086 & 0.0928 & 0.0005 & 0.1233 & 0.0013 & 1.449 & \begin{tabular}{l|l|}
0.032 \\
\end{tabular} & 0.0835 & 0.0016 & 0.484 & 750 & 8 & 1280 & 38 & 41 \\
\hline 9.1 & 526 & 142 & 0.27 & 705.5 & 0.000043 & $\begin{array}{l}0.07 \\
\end{array}$ & 4.286 & 0.047 & 0.1064 & 0.0005 & 0.2332 & 0.0025 & 3.403 & 0.041 & 0.1058 & 0.0005 & 0.904 & 1351 & 13 & 1729 & 9 & 22 \\
\hline 10.1 & 315 & 183 & 0.58 & 70.2 & 0.000119 & 0.20 & 3.849 & 0.044 & 0.1049 & 0.0007 & 0.2593 & 0.0030 & 3.691 & 0.054 & 0.1032 & 0.0009 & 0.794 & 1486 & 15 & 1683 & 16 & 12 \\
\hline 11.1 & 380 & 147 & 0.39 & 67.0 & 0.000092 & 0.15 & 4.881 & 0.056 & 0.1033 & 0.0006 & 0.2045 & 0.0023 & 2.877 & 0.040 & 0.1020 & 0.0008 & 0.827 & 1200 & 13 & 1861 & 14 & 28 \\
\hline 12.1 & 606 & 261 & 0.43 & 142.3 & 0.000031 & 0.05 & 3.658 & 0.041 & 0.1569 & 0.0007 & 0.2732 & 0.0030 & 5.897 & 0.071 & 0.1565 & 0.0007 & 0.922 & 1557 & 15 & 2419 & 8 & 36 \\
\hline 13.1 & 128 & 122 & 0.95 & 21.1 & 0.000198 & 0.33 & \begin{tabular}{|l|l|}
5.224 \\
\end{tabular} & $\begin{array}{ll}0.073 \\
\end{array}$ & 0.1028 & 0.0012 & 0.1908 & 0.0027 & 2.633 & $\begin{array}{l}0.060 \\
\end{array}$ & 0.1001 & 0.0018 & 0.615 & 1126 & 15. & 1626 & 34 & 31 \\
\hline 14.1 & 550 & 284 & 0.52 & $10 \div .0$ & 0.000053 & 0.09 & $\begin{array}{l}4.679 \\
\end{array}$ & $\begin{array}{l}0.051 \\
\end{array}$ & 0.1035 & 0.0008 & 0.2135 & 0.0023 & 3.024 & $\begin{array}{l}0.042 \\
\end{array}$ & 0.1027 & 0.0009 & \begin{tabular}{|l||}
0.795 \\
\end{tabular} & 1248 & 12 & 1674 & 15 & 25 \\
\hline 15.1 & 545 & 300 & 0.55 & 126.9 & 0.000106 & 0.18 & 3.692 & $\begin{array}{l}0.039 \\
\end{array}$ & 0.1048 & 0.0010 & 0.2704 & 0.0029 & 3.853 & 0.059 & $\begin{array}{l}0.1033 \\
\end{array}$ & 0.0011 & \begin{tabular}{l|l}
0.693 \\
\end{tabular} & 1543 & 15 & 1685 & 20 & 8 \\
\hline 15.2 & 923 & 287 & 0.31 & 96.7 & 0.001155 & 1.95 & 8.193 & 0.090 & 0.0929 & 0.0012 & 0.1197 & 0.0013 & 1.262 & 0.051 & 0.0765 & 0.0030 & 0,274 & 729 & 8 & 1108 & 78 & 34 \\
\hline 16.1 & 224 & 177 & 0.79 & 50.6 & 0.000023 & 0.04 & 3.800 & 0.045 & 0.0998 & 0.0007 & 0.2631 & 0.0031 & 3.609 & 0.052 & \begin{tabular}{|c|}
0.0995 \\
\end{tabular} & 0.0008 & 0.830 & 1506 & 16 & 1614 & 15 & 7 \\
\hline 16.2 & 125 & 60 & 0.48 & 32.7 & 0.000304 & 0.51 & 3.285 & 0.045 & 0.1041 & 0.0010 & 0.3063 & 0.0042 & 4.603 & 0.081 & 0.1090 & 0.0012 & 0.779 & 1722 & 22 & 1783 & 20 & 3 \\
\hline 17.1 & 1068 & 204 & 0.19 & 129.9] & 0.000743 & 1.26 & 7.063 & 0.080 & 0.0954 & 0.0005 & 0.1398 & 0.0016 & 1.638 & 0.041 & 0.0850 & 0.0019 & 0.460 & 844 & 9) & 1314 & 43 & 36 \\
\hline 17.2 & 471 & 65 & 0.14 & 101.8 & 0.000139 & 0.24 & 3.971 & 0.047 & 0.0998 & 0.0008 & 0.2512 & 0.0030 & 3.391 & 0.053 & \begin{tabular}{l|l}
0.0979 \\
\end{tabular} & 0.0010 & 0.770 & 1445 & 15 & 1584 & 19 & 9 \\
\hline 18.1 & 208 & 116 & 0.56 & 52.7 & 0.000015 & $\begin{array}{l}0.03 \\
\end{array}$ & 3.395 & 0.039 & 0.1027 & 0.0006 & 0.2945 & 0.0034 & 4.163 & 0.055 & 0.1025 & 0.0007 & 0.873 & 1664 & 17 & 1671 & 12 & 0 \\
\hline 18.2 & 583 & 157 & 0.27 & 96.9 & 0.000541 & 0.91 & 5.175 & 0.056 & 0.0987 & 0.0005 & 0.1915 & 0.0021 & 2.407 & 0.045 & 0.0912 & 0.0014 & 0.585 & 1129 & 11 & 1450 & 29 & 22 \\
\hline \begin{tabular}{l|l|}
19.1 \\
\end{tabular} & 143 & 46 . & 0.32 & 38.3 & 0.000105 & 0.18 & 3.216 & 0.039 & 0.1059 & 0.0007 & 0.3116 & 0.0038 & 4.627 & 0.066 & 0.1077 & 0.0008 & 0.863 & 1749 & 20 & 1761 & 13) & 1 \\
\hline 20.1 & 1961 & 482 & 0.25 & 210.8 & 0.000767 & 1.30 & 7.993 & 0.093 & 0.0968 & 0.0009 & 0.1235 & 0.0015 & 1.465 & 0.046 & 0.0861 & 0.0025 & 0.380 & 751 & 8 & 1340 & 56 & 44 \\
\hline 21.1 & 216 & 100 & 0.50 & 56.4 & 0.000005 & 0.01 & 3.294 & 0.038 & 0.1012 & 0.0006 & 0.3035 & \begin{tabular}{l|l}
0.0035 \\
\end{tabular} & 4.231 & 0.055 & 0.1011 & 0.0006 & 0.888 & 1709 & 17 & 1644 & 11 & -4 \\
\hline 21.2 & 530 & 126 & 0.24 & 89.4 & 0.003500 & 5.91 & 5.097 & 0.065 & 0.1322 & 0.0066 & \begin{tabular}{l|l|}
0.1846 \\
\end{tabular} & 0.0028 & 2.111 & $\begin{array}{l}0.293 \\
\end{array}$ & 0.0829 & 0.0114 & 0.108 & 1092 & 15 & 1267 & 269 & 14 \\
\hline 22.1 & 389 & 322 & 0.83 & 106.4 & 0.000048 & 0.08 & 3.141 & 0.036 & 0.1061 & 0.0005 & 0.3228 & 0.0037 & 5.219 & 0.088 & 0.1173 & 0.0014 & 0.678 & 1803 & 20 & 1915 & 22 & 6 \\
\hline 23.1 & 404 & 192 & 0.47 & 111.2 & 0.000049 & 0.08 & 3.123 & 0.034 & 0.1052 & 0.0005 & 0.3201 & 0.0035 & 4.638 & 0.055 & 0.1051 & 0.0005 & 0.929 & 1790 & 18 & \begin{tabular}{|l|l|}
1716 \\
\end{tabular} & 8 & -4 \\
\hline 24.1 & 242 & 208 & 0.86 & 44.5 & 0.001430 & 2.42 & 4.676 & 0.055 & 0.1150 & 0.0008 & 0.2087 & 0.0025 & 2.737 & 0.102 & 0.0951 & 0.0034 & 0.320 & 1222 & 13 & 1530 & 67 & 20 \\
\hline 25.1 & 364 & 166 & 0.46 & 99.4 & 0.000012 & $\begin{array}{ll}0.02 \\
\end{array}$ & \begin{tabular}{|l|l|}
3.148 & \\
\end{tabular} & 0.035 & \begin{tabular}{|l|l}
0.1036 \\
\end{tabular} & 0.0005 & 0.3176 & 0.0035 & 4.530 & 0.054 & 0.1034 & 0.0005 & \begin{tabular}{l|l}
0.922 \\
\end{tabular} & 1778 & 17 & \begin{tabular}{ll|}
1687 \\
\end{tabular} & 9 & -5 \\
\hline 26.1 & 115 & 54 & 0.47 & 35.4 & 0.000483 & 0.82 & 2.801 & 0.037 & 0.1156 & 0.00111 & 0.3591 & \begin{tabular}{|c|}
0.0048 \\
\end{tabular} & \begin{tabular}{|l|l}
5.956 \\
\end{tabular} & 0.101 & 0.1203 & 0.0013 & 0.781 & 1978 & 24 & 1960 & 19 & -1 \\
\hline 27.1 & 195 & 59 & 0.30 & 49.6 & 0.000056 & 0.10 & 3.379 & 0.040 & \begin{tabular}{l|l|l}
0.1026 \\
\end{tabular} & 0.0007 & 0.2956 & 0.0035 & \begin{tabular}{ll|}
4.152 \\
\end{tabular} & $\begin{array}{ll}0.063 \\
\end{array}$ & 0,1019 & 0.0010 & 0.781 & 1670 & 17 & 1658 & 17 & -1 \\
\hline 28.1 & 205 & 94. & 0.46 & 56.0 & 0.000004 & 0.01 & \begin{tabular}{|l|l|}
3.143 \\
\end{tabular} & 0.037 & 0.1037 & 0.0006 & \begin{tabular}{|l|}
0.3181 \\
\end{tabular} & 0.0037 & 4.546 & 0.061 & 0.1036 & 0.0007 & \begin{tabular}{ll|l}
0.876 \\
\end{tabular} & 1781 & 18 & 1690 & 12 & -5 \\
\hline 29.1 & 814 & 246 & 0.30 & 134.1 & 0.000324 & 0.55 & 5.214 & 0.055 & 0.1089 & 0.0005 & 0.1907 & 0.0020 & 2.747 & 0.039 & 0.1044 & 0.0010 & 0.759 & 1125 & 11 & 1705 & 17 & 34 \\
\hline 30.1 & 221 & 32 & 0.15 & 46.2 & 0.000128 & $\begin{array}{ll}0.22 \\
\end{array}$ & 4.101 & 0.052 & $\begin{array}{ll}0.1046 \\
\end{array}$ & 0.0008 & 0.2433 & 0.0031 & 3.451 & 0.056 & 0.1029 & 0.0010 & 0.787 & 1404 & 16 & 1676 & 19 & 16 \\
\hline 31.1 & 1103 & 374 & 0.34 & 240.5 & 0.000328 & 0.55 & 3.940 & 0.041 & 0.1081 & 0.0003 & 0.2524 & 0.0026 & 3.606 & 0.048 & 0.1036 & 0.0008 & 0.789 & 1451 & 14. & 1690 & 15 & 14 \\
\hline 32.1 & 312 & 58 & 0.19 & 89.9 & 0.000020 & 0.03 & 2.980 & 0.034 & 0.1054 & 0.0006 & 0.3356 & 0.0038 & 4.875 & 0.062 & 0.1054 & 0.0006 & 0.901 & 1865 & 19 & 1721 & 10 & -8 \\
\hline 33.1 & 478 & 60 . & 0.13 & 125.7 & 0.000017 & 0.03 & 3.267 & \begin{tabular}{|l|l|}
0.037 \\
\end{tabular} & $\begin{array}{ll}0.1067 \\
\end{array}$ & 0.0006 & 0.3060 & 0.0035 & 4.491 & $\begin{array}{ll}0.058 \\
\end{array}$ & 0.1064 & 0.0006 & 0.889 & 1721 & 17) & 1739 & 11 & 1 \\
\hline 34.1 & 492 & 174 & 0.35 & 119.7 & 0.000004 & 0.01 & 3.529 & 0.041 & \begin{tabular}{l|l}
0.1106 \\
\end{tabular} & 0.0007 & 0.2833 & 0.0033 & 4.320 & $\begin{array}{l}0.056 \\
\end{array}$ & 0.1106 & 0.0007 & 0.887 & 1608 & \begin{tabular}{l|l}
16 \\
\end{tabular} & 1809 & 11 & 11 \\
\hline 35.1 & 348 & 227 & 0.65 & 66.0 & 0.000081 & 0.14 & $\begin{array}{ll}4.528 \\
\end{array}$ & $\begin{array}{l}0.056 \\
\end{array}$ & $\begin{array}{ll}0.0922 \\
\end{array}$ & 0.0008 & 0.2206 & 0.0027 & 2.770 & 0.046 & 0.0911 & 0.0010 & 0.745 & 1285 & 14 & 1448. & 21 & 11 \\
\hline 36.1 & 1573 & 214 & 0.14 & \begin{tabular}{|l|l|}
339.0 \\
\end{tabular} & 0.000034 & $\begin{array}{ll}0.06 \\
\end{array}$ & 3.985 & 0.042 & 0.1069 & 0.0004 & 0.2508 & 0.0026 & 3.681 & 0.042 & 0.1065 & 0.0004 & 0.936 & 1443 & 14 & 1740 & 7 & 17 \\
\hline 37.1 & 794 & 322 & 0.41 & \begin{tabular}{|l|l|}
185.9 & \\
\end{tabular} & 0.000085 & 0.14 & 3.670 & 0.041 & 0.1086 & 0.0006 & 0.2721 & \begin{tabular}{l|l}
0.0030 \\
\end{tabular} & $\begin{array}{l}.032 \\
\end{array}$ & 0.052 & 0.1075 & 0.0007 & 0.868 & 1551 & 15 & 1757 & 12 & 12 \\
\hline 38.1 & 110 & 29 & 0.27 & 31.3 & - & $<0.01$ & \begin{tabular}{|l|}
3.023 \\
\end{tabular} & \begin{tabular}{|l|l|}
0.043 \\
\end{tabular} & \begin{tabular}{|l|l|l} 
\\
\end{tabular} & 0.0011 & \begin{tabular}{|l|l|l|}
0.3309 \\
\end{tabular} & 0.0047 & $\begin{array}{l}5.270 \\
\end{array}$ & 0.092 & 0.1155 & 0.0011 & \begin{tabular}{l||}
0.822 \\
\end{tabular} & 1843 & \begin{tabular}{l|l|}
23 & \\
\end{tabular} & \begin{tabular}{l|l|}
1888 \\
\end{tabular} & \begin{tabular}{l|l}
18 \\
\end{tabular} & 2 \\
\hline 39.1 & 1924 & 122 & 0.06 & 364.2 & 0.000093 & 0.16 & 4.539 & 0.047 & 0.1027 & 0.0003 & \begin{tabular}{l|l|}
0.2199 \\
\end{tabular} & 0.0023 & 3.075 & 0.033 & 0.1014 & 0.0004 & 0.943 & 1282 & \begin{tabular}{l|l}
12 \\
\end{tabular} & 1650 & 7 & 22 \\
\hline 40.1 & 245 & 104 & 0.42 & 67.6 & 0.000011 & 0.02 & 3.116 & $\begin{array}{l}0.037 \\
\end{array}$ & 0.1067 & 0.0007 & 0.3209 & \begin{tabular}{|l|l|}
0.0038 \\
\end{tabular} & \begin{tabular}{ll|}
4.716 \\
\end{tabular} & 0.068 & 0.1066 & 0.0008 & 0.835 & 1794 & \begin{tabular}{l|l|}
19 & \multicolumn{1}{|c|}{} \\
\end{tabular} & 1742 & 14 & -3 \\
\hline 41.1 & 172. & 76 & 0.44 & 46.8 & $=$ & $<0.01$ & 3.161 & 0.047 & 0.1072 & 0.0011 & 0.3164 & 0.0047 & 4.676 & 0.084 & 0.1072 & 0.0011 & 0.834 & $\begin{array}{l}1772 \\
\end{array}$ & 23 & 1752 & 18 & -1 \\
\hline 42.1 & 213 & 45 & 0.21 & 55.4 & 0.000092 & 0.14 & 3.299 & 0.046 & 0.1054 & 0.0009 & 0.3027 & 0.0042 & $\begin{array}{l}4.347 \\
\end{array}$ & 0.078 & 0.1041 & 0.0012 & 0.777 & 1705 & 21 & 1699 & 21 & 0 \\
\hline 43.1 & 397 & $\begin{array}{ll}126 \\
\end{array}$ & 0.32 & 91.0 & 0.000061 & 0.10 & 3.742 & 0.047 & 0.1045 & 0.0007 & 0.2670 & 0.0033 & 3.815 & 0.059 & $\begin{array}{l}0.1036 \\
\end{array}$ & 0.0009 & 0.816 & 1525 & 17 & 1690 & 16 & 10 \\
\hline 44.1 & 413 & 142 & 0.34 & 105.3 & - & $<0.01$ & 3.373 & 0.041 & 0.1047 & 0.0006 & 0.2965 & $\begin{array}{l}0.0036 \\
\end{array}$ & 4.286 & $\begin{array}{ll}0.059 \\
\end{array}$ & \begin{tabular}{l|l|}
0.1048 \\
\end{tabular} & $\begin{array}{l}0.0006 \\
\end{array}$ & 0.892 & $\begin{array}{l}1674 \\
\end{array}$ & 18 & 1711 & 11 & 2 \\
\hline 45.1 & 197 & 129 & 0.66 & 50.0 & 0.000269 & 0.43 & $\begin{array}{l}3.384 \\
\end{array}$ & 0.050 & 0.1060 & 0.0011 & 0.2943 & 0.0044 & 4.153 & $\begin{array}{l}0.089 \\
\end{array}$ & $\begin{array}{ll}0.1024 \\
\end{array}$ & 0.0016 & \begin{tabular}{ll|}
0.691 \\
\end{tabular} & 1663 & 22 & 1667 & 29 & 0 \\
\hline 46.1 & 484 & 178 & \begin{tabular}{|l|l|}
0.37 \\
\end{tabular} & 123.4 & 0.000020 & 0.03 & 3.373 & 0.041 & 0.1033 & 0.0006 & 0.2963 & $\begin{array}{l}0.0036 \\
\end{array}$ & 4.211 & 0.059 & 0.1031 & 0.0007 & 0.861 & 1673 & 18 & 1680 & 13 & 0 \\
\hline 47.1 & 1725 & 502 & $\begin{array}{ll}0.29 \\
\end{array}$ & 268.9 & 0.000492 & 0.78 & 5.510 & 0.059 & 0.1091 & 0.0004 & 0.1801 & 0.0019 & 2.542 & 0.040 & 0.1024 & 0.0012 & 0.682 & 1067 & 11 & 1668 & 21 & 36 \\
\hline 48.1 & 93 & 47 & 0.51 & 24.2 & 0.000048 & 0.08 & 3.297 & 0.063 & 0.1063 & 0.0015 & 0.3031 & 0.0058 & 4.414 & 0.106 & 0.1056 & 0.0015 & 0.799 & 1707 & 29 & 1725 & 27 & 1 \\
\hline 50,1 & 265 & 147 & 0.55 & 67.4 & $=$ & $<0.01$ & 3.384 & 0.046 & 0.1047 & 0.0009 & 0.2957 & 0.0040 & \begin{tabular}{ll|}
4.289 \\
\end{tabular} & 0.073 & 0.1052 & 0.0011 & 0.802 & 1670 & 20 & 1718 & 19 & 3 \\
\hline 54.1 & 189 & 77 & \begin{tabular}{l|l|}
0.41 \\
\end{tabular} & 50.2 & 0.000010 & 0.01 & 3.236 & 0.046 & 0.1080 & 0.0010 & 0.3090 & 0.0044 & $\begin{array}{l}.598 \\
\end{array}$ & 0.078 & 0.1079 & 0.0010 & \begin{tabular}{l|l}
0.834 \\
\end{tabular} & $\begin{array}{l}7366 \\
\end{array}$ & 22 & 1765 & 17 & 2 \\
\hline 52.1 & 209 & 100 & 0.48 & 50.1 & 0.000040 & 0.06 & 3.585 & 0.051 & 0.1036 & 0.0009 & 0.2787 & 0.0040 & 3.960 & 0.068 & 0.1030 & $\begin{array}{l}0.0010 \\
\end{array}$ & 0.828 & 1585 & 20 & $\begin{array}{l}1679 \\
\end{array}$ & 18 & 6 \\
\hline 53.1 & 108 & 77 & 0.71 & 27.2 & - & $<0.01$ & 3.415 & 0.057 & 0.1037 & 0.0013 & 0.2930 & $\begin{array}{l}0.0049 \\
\end{array}$ & \begin{tabular}{l|l|}
4.222 \\
\end{tabular} & 0.093 & 0.1045 & 0.0015 & 0.767 & 1657 & 25 & 1705 & 26 & 3 \\
\hline 54.1 & 233 & 58 & 0.25 & $\begin{array}{l}54.9 \\
\end{array}$ & 0.000064 & 0.10 & $\begin{array}{ll}3.651 \\
\end{array}$ & $\begin{array}{l}0.050 \\
\end{array}$ & 0.1034 & 0.0009 & $\begin{array}{l}0.2736 \\
\end{array}$ & 0.0038 & \begin{tabular}{l|l}
3.868 \\
\end{tabular} & 0.068 & 0.1025 & 0.0011 & 0.782 & 1559 & 19 & 1670 & 20 & 7 \\
\hline 55.1 & 378 & 83 & 0.22 & 91.5 & - & $<0.01$ & 3.550 & 0.044 & 0.1055 & 0.0007 & 0.2818 & 0.0035 & 4.111 & 0.059 & 0.1058 & 0.0007 & 0.872 & 1600 & 18 & 1729 & 13 & 7 \\
\hline 56.1 & 1463 & 940 & 0.64 & 299.6 & 0.000096 & 0.15 & 4.196 & 0.045 & 0.1028 & 0.0004 & 0.2379 & 0.0025 & 3.330 & 0.039 & 0.1015 & 0.0005 & 0.913 & $\begin{array}{ll}1376 \\
\end{array}$ & 13 & 1652 & 9 & 17 \\
\hline $\begin{array}{l}57.1 \\
\end{array}$ & 1723 & 298 & 0.17 & 175.5 & 0.001149 & 1.88 & 8.436 & \begin{tabular}{|l|l|}
0.092 \\
\end{tabular} & 0.1035 & 0.0004 & 0.1163 & 0.0013 & 1.402 & 0.042 & 0.0874 & 0.0024 & 0.370 & 709 & 7 & $\begin{array}{l}1370 \\
\end{array}$ & 53 & 48 \\
\hline 58.1 & 117 & 38 & 0.32 & 29.6 & 0.000094 & 0.15 & 3.394 & 0.056 & \begin{tabular}{l|l|}
0.1055 \\
\end{tabular} & 0.0012 & 0.2942 & 0.0049 & $\begin{array}{l}4.227 \\
\end{array}$ & 0.107 & 0.1042 & 0.0020 & 0.654 & $\begin{array}{ll}1662 \\
\end{array}$ & 24 & 1701 & 35 & 2 \\
\hline 59.1 & 223 & 138 & 0.62 & 54.2 & $\begin{array}{l}0.000045 \\
\end{array}$ & 0.07 & 3.535 & 0.049 & 0.1045 & 0.0009 & 0.2827 & 0.0039 & 4.049 & 0.070 & 0.1039 & 0.0011 & 0.799 & 1605 & 20 & 1695 & 19 & 5 \\
\hline 60.1 & 867 & 242 & $\begin{array}{l}0.28 \\
\end{array}$ & 134.3 & 0.000393 & 0.63 & 5.549 & 0.062 & 0.1045 & 0.0005 & 0.1791 & 0.0020 & 2.447 & 0.039 & 0.0991 & 0.0011 & 0.695 & 1062 & 11 & 1608 & 22 & 34 \\
\hline & & & & & & & & & & & & & & & & & & & & & & \\
\hline & & & & & & & & & & & & & & & & & & & & & & \\
\hline es: & & 1. Unes & ertainties: & 3 given at 1 & one o level. & & & & & & & & & & & & & & & & & \\
\hline & & 2. Error & in FC1 & Reference & on calibratic & tion was & $0.89 \% \& 0$ & $.50 \%$ for & e analytical & sessions. & & & & & & & & & & & & \\
\hline & & & (not ind & uded in ab & ve errors but & required & when $\infty$ & nparing da & ta from diffe & ont mounts) & & & & & & & & & & & & \\
\hline & & 3. $\mathrm{f}_{2005} \%$ & \% denote & is the perc & ntage of ${ }^{200} \mathrm{~Pb}$ & 6 that is & common $P$ & & & & & & & & & & & & & & & \\
\hline & & 4. For 2 & areas old & der than -8 & O Ma corracti & tion for $\mathrm{c}$ & ommon $\mathrm{Pb}$ & made usi & ng the mee & $\operatorname{red}^{204} \mathrm{pb} / 2$ & pbratio. & & & & & & & & & & & \\
\hline & & 5. For & $\%$ Disc, & \% denote & concordant & it analysi: & & & & & & & & & & & & & & & & \\
\hline
\end{tabular}


TABLE 3H.-Summary of SHRIMP U-Pb zircon results for sample 95ITz101.

\begin{tabular}{|c|c|c|c|c|c|c|c|c|c|c|c|c|c|c|c|c|c|c|c|c|c|c|}
\hline & & & & & & & & Total R & atios & & & & adiogenic & Satios & & & & & & (Ma) & & \\
\hline Grain. & U & Th & Th/U & ${ }^{206} \mathrm{~Pb}^{4}$ & ${ }^{204} \mathrm{~Pb} /$ & $f_{206}$ & ${ }^{230} \mathrm{U} /$ & & ${ }^{207} \mathrm{~Pb} /$ & & ${ }^{200} \mathrm{~Pb} /$ & & ${ }^{207} \mathrm{~Pb} /$ & & ${ }^{207} \mathrm{~Pb} /$ & & & ${ }^{205} \mathrm{~Pb} /$ & & $207 \mathrm{~Pb} /$ & & $\%$ \\
\hline spot & (ppm) & (ppm) & & (ppm) & ${ }^{206} \mathrm{~Pb}$ & $\%$ & ${ }^{206} \mathrm{~Pb}$ & \pm & ${ }^{205} \mathrm{~Pb}$ & \pm & ${ }^{238} \mathrm{U}$ & \pm & ${ }^{235} \mathrm{U}$ & \pm & ${ }^{206} \mathrm{~Pb}$ & \pm & $\rho$ & ${ }^{238} \mathrm{U}$ & \pm & $208 \mathrm{~Pb}$ & \pm & Disc \\
\hline & & & & & & & & & & & & & & & & & & & & & & \\
\hline 1.1 & 219 & 96 & 0.44 & 58 & 0.000161 & 0.29 & 3.274 & 0.047 & 0.1076 & 0.0006 & 0.3046 & 0.0044 & 4.426 & 0.072 & 0.1054 & 0.0008 & 0.889 & 1714 & 22 & 1721 & 7 & 0 \\
\hline 2.1 & 278 & 135 & 0.48 & 73 & 0.000067 & 0.12 & 3.287 & 0.047 & 0.1057 & 0.0005 & 0.3039 & 0.0043 & 4.392 & $\begin{array}{l}0.067 \\
\end{array}$ & 0.1048 & 0.0006 & 0.928 & 1711 & 21 & 1711 & 5 & 0 \\
\hline 2.2 & 1049 & 446 & 0.43 & 138 & 0.000402 & 0.73 & 6.549 & 0.091 & 0.1013 & 0.0005 & 0.1516 & 0.0021 & 2.000 & $\begin{array}{l}0.033 \\
\end{array}$ & 0.0957 & 0.0008 & 0.848 & 910 & 12 & 1542 & 8 & 41 \\
\hline 3.1 & 70 & 38 & 0.55 & 18) & 0.000359 & 0.65 & 3.302 & 0.052 & 0.1071 & 0.0011 & 0.3009 & 0.0049 & 4.240 & 0.124 & 0.1022 & 0.0025 & 0.550 & 1696 & 24 & 1665 & 23 & -2 \\
\hline 4.1 & 473 & 131 & 0.28 & 113 & 0.000041 & 0.07 & 3.597 & 0.050 & 0.1040 & 0.0004 & 0.2778 & 0.0039 & \begin{tabular}{l|l|}
3.963 \\
\end{tabular} & 0.058 & 0.1035 & 0.0005 & 0.949 & 1580 & 20 & 1687 & 4 & 6 \\
\hline 5.1 & 162 & 58 & 0.35 & 42 & 0.000081 & 0.15 & 3.304 & 0.048 & 0.1065 & 0.0007 & 0.3023 & 0.0044 & 4.392 & 0.073 & 0.1054 & 0.0008 & 0.885 & 1703 & 22 & 1721 & 7 & 1 \\
\hline 6.1 & 181 & 91 & 0.50 & 46 & 0.000145 & 0.26 & 3.387 & 0.049 & 0.1069 & 0.0007 & 0.2945 & 0.0043 & 4.261 & 0.073 & 0.1049 & 0.0009 & 0.850 & 1664 & 21 & \begin{tabular}{|c|}
1713 \\
\end{tabular} & 8 & 3 \\
\hline 7.1 & 149 & 188 & 1.26 & 40 & 0.000085 & 0.15 & 3.198 & 0.047 & \begin{tabular}{|c|}
0.1059 \\
\end{tabular} & 0.0007 & 0.3122 & 0.0046 & 4.507 & $\begin{array}{ll}0.076 \\
\end{array}$ & \begin{tabular}{|l|l|l|l}
0.1047 \\
\end{tabular} & 0.0009 & 0.873 & $175 t$ & 23 & 1709 & 8 & -2 \\
\hline 8.1 & 121 & \begin{tabular}{|l|}
42 \\
\end{tabular} & 0.35 & 31 & 0.000302 & 0.55 & 3.317 & 0.050 & 0.1073 & 0.0012 & 0.2998 & 0.0045 & 4.264 & 0.086 & 0.1031 & 0.0014 & 0.746 & 1690 & 22 & 1681 & 12 & -1 \\
\hline 9.1 & \begin{tabular}{l|l|}
1179 \\
\end{tabular} & \begin{tabular}{|l|l|}
98 \\
\end{tabular} & 0.08 & 296 & 0.000036 & 0.07 & 3.425 & 0.047 & 0.1035 & 0.0003 & 0.2918 & 0.0040 & 4.143 & 0,059 & 0.1030 & 0.0004 & 0.970 & 1650 & 20 & $\begin{array}{l}1679 \\
\end{array}$ & 3 & 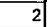 \\
\hline 10.1 & 761 & 392 & 0.52 & 278 & 0.000066 & 0.12 & 2.353 & 0.035 & \begin{tabular}{|l|l|}
0.1977 \\
\end{tabular} & 0.0005 & \begin{tabular}{|l|l|}
0.4246 \\
\end{tabular} & 0.0063 & 11.528 & $\begin{array}{l}0.172 \\
\end{array}$ & 0.1969 & 0.0005 & 0.985 & 2281 & 28 & 2801 & 2 & 19 \\
\hline 11.1 & 276 & 99 & 0.36 & 73 & 0.000132 & 0.24 & 3.245 & 0.046 & 0.1074 & 0.0007 & \begin{tabular}{l|l|}
0.3074 \\
\end{tabular} & 0.0044 & 4.475 & 0.073 & $\begin{array}{ll}0.1056 \\
\end{array}$ & 0.0008 & 0.880 & 1728 & 22 & $\begin{array}{l}1724 \\
\end{array}$ & 7 & 0 \\
\hline 12.1 & 397 & 99 & 0.25 & 171 & 0.000070 & 0.13 & 1.992 & 0.030 & 0.1877 & 0.0007 & \begin{tabular}{|l|}
0.5014 \\
\end{tabular} & \begin{tabular}{l|l}
0.0075 \\
\end{tabular} & 12.919 & 0.200 & \begin{tabular}{|c|}
0.1869 \\
\end{tabular} & 0.0008 & 0.963 & 2620 & 32 & 2715 & 3 & 4 \\
\hline 13.1 & 175 & 78 & 0.45 & 47 & 0.000149 & $\begin{array}{ll}0.27 \\
\end{array}$ & 3.192 & 0.043 & 0.1065 & 0.0008 & 0.3125 & 0.0042 & 4.500 & 0.074 & 0.1045 & 0.0010 & \begin{tabular}{l||}
0.824 \\
\end{tabular} & 1753 & 21 & 1705 & 9 & -3 \\
\hline 14.1 & 1268 & 47 & 0.04 & 346 & 0.000025 & 0.04 & 3.153 & 0.045 & 0.1081 & 0.0003 & \begin{tabular}{l|l|l}
0.3170 \\
\end{tabular} & 0.0045 & 4.708 & $\begin{array}{l}0.069 \\
\end{array}$ & \begin{tabular}{|l|}
0.1077 \\
\end{tabular} & 0.0003 & 0.978 & $\begin{array}{l}1775 \\
\end{array}$ & 22 & 1761 & 3 & -1 \\
\hline 15.1 & 178 & 73 & 0.41 & 52 & 0.000092 & 0.17 & 2.931 & 0,043 & 0.1137 & 0.0008 & 0.3406 & 0.0050 & 5.280 & $\begin{array}{l}0.087 \\
\end{array}$ & 0.1124 & 0.0009 & 0.886 & 1889 & 24 & 1839 & 7 & -3 \\
\hline 16.1 & 199 & \begin{tabular}{l|l}
63 \\
\end{tabular} & 0.32 & 50 & 0.000145 & 0.26 & 3.383 & 0.058 & 0.1060 & 0.0008 & 0.2948 & 0.0051 & 4.226 & 0.083 & 0.1040 & 0.0010 & 0.880 & 1665 & 25 & 1696 & 9 & 2 \\
\hline \begin{tabular}{|l|}
77.1 \\
\end{tabular} & 225 & 52 & $\begin{array}{ll}0.23 \\
\end{array}$ & 50 & 0.000264 & 0.48 & 3.838 & 0.052 & 0.1052 & 0.0008 & 0.2593 & 0.0035 & 3.632 & $\begin{array}{l}0.0633 \\
\end{array}$ & 0.1016 & 0.0011 & \begin{tabular}{|l|l|}
0.783 \\
\end{tabular} & \begin{tabular}{l|l}
1486 \\
\end{tabular} & 18 & 1653 & 10 & 10 \\
\hline 18.1 & 388 & 159 & 0.41 & 104 & 0.000067 & 0.12 & 3.194 & 0.043 & 0.1055 & 0.0010 & \begin{tabular}{|c|}
0.3127 \\
\end{tabular} & 0.0042 & 4.507 & \begin{tabular}{l|l}
0.077 \\
\end{tabular} & $\begin{array}{ll}0.1045 \\
\end{array}$ & 0.0011 & 0.798 & 1754 & 21 & 1706 & 9 & -3 \\
\hline 19.1 & 166 & 54 & 0.32 & \begin{tabular}{l|l|}
47 \\
\end{tabular} & 0.000211 & 0.38 & 3.012 & 0.044 & 0.1129 & 0.0009 & 0.3307 & 0.0048 & 5.017 & 0.103 & 0.1100 & \begin{tabular}{l|l}
0.0016 \\
\end{tabular} & 0.713 & 1842 & 23 & 1800 & 133 & -2 \\
\hline 20.1 & 890 & 410 & 0.47 & 215 & 0.000099 & 0.18 & \begin{tabular}{|l|}
3.562 \\
\end{tabular} & 0.049 & 0.1053 & 0.0004 & 0.2802 & \begin{tabular}{|l|}
0.0039 \\
\end{tabular} & 4.017 & 0.058 & 0.1040 & 0.0004 & 0.956 & 1593 & 20 & 1696 & 4 & 6 \\
\hline 21.1 & 189 & 225 & 1.19 & 52 & 0.000142 & 0.26 & \begin{tabular}{|l|l|}
3.105 \\
\end{tabular} & 0.045 & 0.1113 & 0.0008 & 0.3212 & \begin{tabular}{|c|}
0.0047 \\
\end{tabular} & 4.843 & 0.081 & $\begin{array}{l}0.1093 \\
\end{array}$ & 0.0009 & 0.864 & 1796 & 23 & 1788 & 8 & 0 \\
\hline 22.1 & 367 & 231 & \begin{tabular}{l|l}
0.63 \\
\end{tabular} & 85 & 0.000086 & 0.16 & 3.315 & 0.051 & 0.1062 & 0.0010 & 0.3012 & 0.0047 & 4.360 & $\begin{array}{l}0.085 \\
\end{array}$ & 0.1050 & 0.0012 & \begin{tabular}{l||}
0.796 \\
\end{tabular} & 1697 & 23 & $\begin{array}{l}1714 \\
\end{array}$ & 11 & 1 \\
\hline 23.1 & 86 & 42 & 0.49 & 44 & 0.000238 & 0.43 & 1.689 & 0.026 & 0.2165 & 0.0013 & 0.5894 & 0.0092 & 17.369 & $\begin{array}{l}0.296 \\
\end{array}$ & 0.2137 & 0.0015 & 0.912 & 2987 & 37 & 2934 & 6 & -2 \\
\hline 24.1 & 465 & 186 & 0.40 & 126 & 0.000037 & 0.07 & 3.164 & 0.045 & 0.1078 & 0.0005 & 0.3159 & $\begin{array}{ll}0.0045 \\
\end{array}$ & 4,672 & 0.071 & 0.1073 & 0.0005 & 0.947 & \begin{tabular}{ll|}
1769 \\
\end{tabular} & 22 & 1754 & 4 & -1 \\
\hline 25.1 & 644 & 276 & $\begin{array}{ll}0.43 \\
\end{array}$ & 176 & 0.000055 & 0.10 & 3.147 & 0.044 & 0.1084 & 0.0006 & 0.3174 & 0.0044 & 4.714 & 0.071 & \begin{tabular}{|c|}
0.1077 \\
\end{tabular} & 0.0006 & 0.919 & \begin{tabular}{|l|}
1777 \\
\end{tabular} & 22 & 1761 & 5 & -1 \\
\hline 26.1 & 223 & 157 & 0.70 & 61 & 0.000172 & 0.31 & \begin{tabular}{|l|l|}
3.153 \\
\end{tabular} & 0.051 & 0.1084 & 0.0007 & 0.3162 & 0.0051 & 4.624 & 0.085 & 0.1061 & 0.0009 & 0.887 & 1771 & 25 & 1733 & 8 & -2 \\
\hline 27.1 & 237 & 115 & $\begin{array}{ll}0.48 \\
\end{array}$ & 66 & 0.000126 & 0.23 & \begin{tabular}{|l|l}
3.075 \\
\end{tabular} & 0.045 & 0.1092 & 0.0011 & 0.3244 & 0.0048 & 4.808 & 0.091 & 0.1075 & 0.0013 & 0.780 & 1811 & 23 & \begin{tabular}{|l|}
1757 \\
\end{tabular} & 11 & -3 \\
\hline 28.1 & 210 & 84 & 0.40 & 54 & 0.000119 & 0.21 & 3.361 & 0.046 & \begin{tabular}{|l|l|l|}
0.1042 \\
\end{tabular} & 0.0008 & \begin{tabular}{l|l|}
0.2969 \\
\end{tabular} & 0.0040 & $\begin{array}{l}4.197 \\
\end{array}$ & 0.068 & 0.1025 & 0.0009 & 0.836 & \begin{tabular}{ll|}
1676 \\
\end{tabular} & 20 & 1670 & 8 & 0 \\
\hline 29.1 & 164 & \begin{tabular}{|l|l|}
48 & \\
\end{tabular} & 0.29 & 42 & 0.000041 & 0.07 & 3.349 & 0.049 & 0.1064 & 0.0009 & 0.2984 & 0.0043 & 4.355 & 0.074 & 0.1058 & 0.0009 & 0.851 & 1683 & 22 & \begin{tabular}{l|l|}
1729 \\
\end{tabular} & 8 & 3 \\
\hline 30.1 & 891 & 429 & 0.48 & 192 & 0.000135 & 0.24 & \begin{tabular}{|l|}
3.987 \\
\end{tabular} & 0.056 & \begin{tabular}{|l|l}
0.1058 \\
\end{tabular} & 0.0004 & 0.2502 & 0.0035 & 3.585 & 0.054 & 0.1039 & 0.0005 & 0.938 & 1440 & 18 & 1695 & 5 & 15 \\
\hline 31.1 & 245 & 105 & 0.43 & 89 & 0.000051 & 0.09 & 2.364 & 0.035 & \begin{tabular}{|l|l|}
0.1615 \\
\end{tabular} & 0.0008 & 0.4226 & 0.0062 & 9.372 & 0.148 & 0.1608 & 0.0009 & 0.936 & 2272 & 28 & 2465 & 5 & 8 \\
\hline 32.1 & 392 & 69 & $\begin{array}{l}0.18 \\
\end{array}$ & 111 & 0.000066 & 0.12 & \begin{tabular}{|c|}
3.034 \\
\end{tabular} & 0.044 & 0.1108 & 0.0006 & 0.3292 & \begin{tabular}{|c|}
0.0048 \\
\end{tabular} & 4.989 & $0.08+$ & 0.1099 & 0.0008 & 0.895 & 1834 & 23 & 1798 & 7 & -2 \\
\hline 33.1 & 585 & 338 & 0.58 & 140 & 0.000176 & 0.32 & 3.588 & 0.050 & 0.1538 & 0.0006 & 0.2778 & 0.0038 & 5.806 & \begin{tabular}{|l|l}
0.085 \\
\end{tabular} & 0.1516 & 0.0007 & 0.945 & 1580 & 19 & 2364 & 4 & 33 \\
\hline 34.1 & 149 & 82 & 0.55 & 38 & 0.000168 & 0.30 & 3.343 & 0.045 & 0.1077 & 0.0009 & 0.2982 & 0.0041 & 4.333 & 0.075 & 0.1054 & 0.0011 & \begin{tabular}{l||}
0.782 \\
\end{tabular} & 1683 & 20 & 1721 & 10 & 2 \\
\hline 35.1 & 272 & 122 & 0.45 & 75 & 0.000079 & 0.14 & 3.109 & 0.044 & 0.1092 & 0.0007 & 0.3212 & 0.0045 & 4.788 & 0.075 & 0.1081 & $\begin{array}{l}0.0007 \\
\end{array}$ & 0.902 & 1796 & 22 & 1768 & 6 & -2 \\
\hline 36.1 & 116 & 128 & 1.10 & 34 & 0.000331 & 0.60 & 2.968 & 0.041 & $\begin{array}{l}0.1179 \\
\end{array}$ & 0.0019 & 0,3350 & 0.0047 & 5.238 & \begin{tabular}{|l|}
0.127 \\
\end{tabular} & 0.1134 & 0.0022 & \begin{tabular}{|l|l|}
0.576 \\
\end{tabular} & 1862 & 23 & 1855 & 18 & 0 \\
\hline 37.1 & 390 & 107 & 0.27 & 110 & 0.000095 & 0.17 & 3.054 & 0.049 & 0.1143 & 0.0006 & 0.3269 & \begin{tabular}{l|l}
0.0052 \\
\end{tabular} & 5.094 & $\begin{array}{l}0.086 \\
\end{array}$ & 0.1130 & 0.0006 & 0.943 & 1823 & 25 & 1848 & 5 & 1 \\
\hline 38.1 & 226 & 105 & 0.46 & 60 & 0.000110 & 0.20 & 3.239 & 0.044 & 0.1056 & 0.0007 & 0.3081 & 0.0042 & 4.424 & 0.072 & 0.1041 & $\begin{array}{l}0.0009 \\
\end{array}$ & 0.838 & 9731 & 21 & 1699 & 8 & -2 \\
\hline 39.1 & 248 & 149 & 0.60 & 67 & 0.000154 & 0.28 & 3.202 & 0.046 & 0.1095 & 0.0006 & 0.3115 & 0.0045 & 4.614 & 0.075 & 0.1074 & 0.0008 & 0.881 & 1748 & 22 & 1756 & 7 & 0 \\
\hline 40.1 & 1033 & 341 & 0.33 & 237 & 0.000069 & 0.12 & 3.742 & 0.051 & 0.1077 & 0.0004 & 0.2669 & 0.0036 & 3.931 & 0.056 & $\begin{array}{ll}0.1068 \\
\end{array}$ & 0.0004 & 0.964 & 1525 & 19 & $\begin{array}{ll}1746 \\
\end{array}$ & 3 & 13 \\
\hline 41.1 & 170 & 113 & 0.66 & 33 & 0.000252 & 0.45 & 4.497 & 0.106 & 0.1018 & 0.0011 & 0.2213 & 0.0052 & 3.002 & 0.083 & 0.0984 & 0.0014 & 0.850 & 1289 & 28 & 1593 & 14 & 19 \\
\hline 42.1 & 1497 & 672 & 0.45 & 225 & 0.000206 & $\begin{array}{l}0.37 \\
\end{array}$ & 5.715 & 0.078 & 0.1004 & 0.0004 & 0.1743 & 0.0024 & 2.345 & \begin{tabular}{ll|}
0.034 \\
\end{tabular} & 0.0976 & 0.0005 & 0.932 & 4036 & \begin{tabular}{l|l}
13 \\
\end{tabular} & 1578 & 5 & 34 \\
\hline 43.1 & 330 & \begin{tabular}{l|l|}
142 \\
\end{tabular} & 0.43 & 85 & 0.000149 & $\begin{array}{l}0.27 \\
\end{array}$ & 3.321 & 0.053 & 0.1056 & 0.0006 & 0.3003 & 0.0048 & 4.289 & $\begin{array}{l}0.077 \\
\end{array}$ & 0.1036 & 0.0009 & 0.888 & 1693 & 24 & $\begin{array}{l}1689 \\
\end{array}$ & 8 & 0 \\
\hline 44.1 & 224 & \begin{tabular}{|l|l|}
108 \\
\end{tabular} & 0.48 & 98 & 0.000070 & 0.13 & 1.955 & 0.028 & 0.1786 & 0.0008 & 0.5108 & \begin{tabular}{|c|}
0.0073 \\
\end{tabular} & 12.521 & 0.191 & 0.1778 & 0.0009 & 0.941 & 2660 & 31 & 2632 & 4 & -1 \\
\hline 45.1 & 284 & 123 & 0.43 & \begin{tabular}{l|l}
74 \\
\end{tabular} & 0.000164 & 0.30 & 3.300 & 0.045 & 0.1090 & 0.0007 & 0.3022 & 0.0041 & 4.448 & 0.071 & 0.1068 & 0.0009 & \begin{tabular}{ll||}
0.853 \\
\end{tabular} & 1702 & 20 & 1745 & 8 & 2 \\
\hline \begin{tabular}{|l|}
46.1 \\
\end{tabular} & 210 & \begin{tabular}{l|l|}
69 & \\
\end{tabular} & $\begin{array}{l}0.33 \\
0.0\end{array}$ & \begin{tabular}{l|l}
53 & \\
\end{tabular} & 0.000193 & 0.35 & 3.391 & 0.053 & |0.1055 & 0.0008 & 0.2939 & 0.0046 & 4.167 & 0.078 & 0.1028 & 0.0011 & 0.839 & 1661 & 23 & 1676 & 9 & 1 \\
\hline 47.1 & 202 & 95 & 0.47 & \begin{tabular}{l|l}
50 \\
\end{tabular} & 0.000222 & 0.40 & 3.469 & 0.050 & \begin{tabular}{|l|l|}
0.1007 \\
\end{tabular} & 0.0008 & 0.2871 & 0.0042 & 3.863 & 0.070 & 0.0976 & 0.0011 & 0.801 & 1627 & 21 & \begin{tabular}{|l|l|}
1578 \\
\end{tabular} & 10 & -3 \\
\hline 48.1 & 294 & 224 & 0.76 & 82 & 0.000202 & \begin{tabular}{l|l}
0.36 \\
\end{tabular} & 3.078 & 0.042 & 0.1162 & 0.0007 & \begin{tabular}{|l|l|}
0.3237 \\
\end{tabular} & 0.0044 & 5.065 & 0.080 & 0.1135 & 0.0009 & 0.855 & 1808 & 21 & \begin{tabular}{|l|l|}
1856 \\
\end{tabular} & 7 & 3 \\
\hline \begin{tabular}{l|l}
49.1 \\
\end{tabular} & 310 & \begin{tabular}{l|l|}
130 \\
\end{tabular} & 0.42 & 82 & 0.000117 & 0.21 & 3.230 & \begin{tabular}{l|l}
0.046 \\
\end{tabular} & 0.1071 & 0.0005 & \begin{tabular}{|l|l}
0.3089 \\
\end{tabular} & 0.0044 & 4.492 & 0.070 & 0.1055 & 0.0007 & 0.914 & 1735 & 22 & \begin{tabular}{ll|}
1722 \\
\end{tabular} & 6 & -1 \\
\hline 50.1 & 241 & \begin{tabular}{|l|}
195 \\
\end{tabular} & 0.81 & \begin{tabular}{l|l}
45 \\
\end{tabular} & 0.000208 & 0.38 & 4.624 & $\begin{array}{l}0.076 \\
\end{array}$ & 0.0932 & 0.0010 & 0.2154 & \begin{tabular}{l|l}
0.0035 \\
\end{tabular} & \begin{tabular}{|l|}
2.683 \\
\end{tabular} & 0.059 & 0.0903 & 0.0013 & 0.744 & 1258 & \begin{tabular}{l|l|}
19 \\
\end{tabular} & 1432 & 14 & 12 \\
\hline 51.7 & $\begin{array}{l}156 \\
\end{array}$ & 50 & $\begin{array}{ll}0.32 \\
\end{array}$ & 41 & 0.000269 & 0.49 & 3.280 & 0.045 & 0.1072 & 0.0015 & 0.3034 & 0.0042 & 4.328 & 0.095 & \begin{tabular}{l|l}
0.1035 \\
\end{tabular} & 0.0017 & 0.635 & 1708 & 21 & \begin{tabular}{|c|}
1687 \\
\end{tabular} & \begin{tabular}{l|l}
16 \\
\end{tabular} & -1 \\
\hline 52.1 & 203 & \begin{tabular}{l|l|}
56 \\
\end{tabular} & 0.28 & $\begin{array}{ll}53 \\
\end{array}$ & 0.000144 & 0.26 & 3.281 & 0.048 & 0.1066 & 0.0013 & \begin{tabular}{|l|}
0.3040 \\
\end{tabular} & 0.0045 & 4.387 & 0.096 & 0.1047 & 0.0017 & 0.669 & 1711 & 22 & \begin{tabular}{|l|l|}
1708 \\
\end{tabular} & \begin{tabular}{l|l|}
15 \\
\end{tabular} & 0 \\
\hline 53.1 & 385 & 105 & 0.27 & 103 & 0.000061 & 0.11 & \begin{tabular}{|l|l|}
3.215 \\
\end{tabular} & 0.044 & 0.1093 & 0.0006 & 0.3107 & 0.0042 & 4.646 & $\begin{array}{l}0.069 \\
\end{array}$ & 0.1085 & 0.0007 & 0.910 & 1744 & 21 & 1774 & 6 & 2 \\
\hline $\begin{array}{l}54.1 \\
\end{array}$ & 237 & 78 & $\begin{array}{ll}0.33 \\
\end{array}$ & 61 & 0.000090 & $\begin{array}{ll}0.16 \\
\end{array}$ & \begin{tabular}{|l|l|}
3.363 \\
\end{tabular} & 0.049 & $\begin{array}{ll}0.1039 \\
\end{array}$ & 0.0007 & 0.2969 & 0.0043 & 4.203 & 0.071 & 0.1027 & 0.0009 & 0.857 & 1676 & 21 & 1673 & 8 & 0 \\
\hline 55.1 & 335 & \begin{tabular}{l|l}
396 \\
\end{tabular} & $\begin{array}{ll}1.18 \\
\end{array}$ & 84 & 0.000137 & 0.25 & 3.420 & 0.050 & 0.1094 & 0.0013 & 0.2917 & 0.0043 & 4.323 & 0.085 & 0.1075 & 0.0014 & 0.740 & 1650 & 21 & 1757 & 12 & 6 \\
\hline 56.1 & 372 & 106 & 0.28 & 100 & 0.000065 & 0.12 & 3.179 & 0.045 & 0.1115 & 0.0006 & 0.3142 & 0.0045 & 4.794 & 0.074 & 0.1106 & 0.0007 & 0.921 & 1762 & 22 & 1810 & 5 & 3 \\
\hline 57.1 & 306 & 72 & 0.23 & 78 & 0.000160 & 0.29 & \begin{tabular}{l|l}
3.355 \\
\end{tabular} & 0.070 & 0.1050 & 0.0006 & 0.2972 & 0.0062 & 4.215 & 0.097 & 0.1028 & 0.0010 & 0.905 & 1678 & 31 & 1676 & 9 & 으. \\
\hline 58.1 & 144 & 40 & 0.28 & 37 & 0.000241 & 0.43 & 3.373 & 0.046 & 0.1075 & 0.0010 & 0.2952 & 0.0040 & 4.243 & 0.079 & 0.1042 & 0.0013 & 0.732 & 1668 & 20 & 1701 & 12 & 2 \\
\hline 59.1 & 534 & 257 & 0.48 & 141 & 0.000009 & 0.02 & 3.266 & 0.046 & 0.1087 & 0.0005 & 0.3061 & 0.0043 & 4.581 & 0.068 & $\begin{array}{l}0.1085 \\
\end{array}$ & 0.0005 & 0.947 & 1722 & 21 & 1775 & 4 & 3 \\
\hline 60.1 & 221 & 114 & 0.52 & 60 & 0.000245 & 0.44 & 3.144 & 0.065 & 0.1100 & 0.0015 & \begin{tabular}{l|l}
0.3167 \\
\end{tabular} & 0.0066 & 4.656 & 0.127 & 0.1066 & 0.0019 & 0.762 & 1774 & 32 & 1742 & 16 & -2 \\
\hline & & & & & & & & & & & & & & & & & & & & & & \\
\hline & & & & & & & & & & & & & & & & & & & & & & \\
\hline Noles & & 1. Une & irtainlies & given a & the one $\sigma$ lev & & & & & & & & & & & & & & & & & \\
\hline & & 2. Error & in $R 33 r$ & eference & zircon calibra & tion wa & $66 \%$ & $\vec{\theta}$ ana & the & & & & & & & & & & & & & \\
\hline & & & ( nas I I MUI) & uded In I & bevou sprutes be & ul rsutul & of whuint & 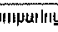 & $\mathrm{PW} / \mathrm{m}$ & fivin! & $1 \mathrm{mu}$ & & & & & & & & & & & \\
\hline & & 3. $f_{208} \%$ & $\%$ denote & $s$ the pe & centage of ${ }^{208} \mathrm{~F}$ & Pb that & common & Pb. & & & & & & & & & & & & & & \\
\hline & & 4. For & areas old & ler than & 800 Ma corre & ction to & common & $b \mathrm{mac}$ & ng the $m$ & ured ${ }^{201}$ & $\mathrm{P}^{\mathrm{P} b} \mathrm{rat}$ & & & & & & & & & & & \\
\hline & & 5. For & areas you & unger th & $n \sim 800 \mathrm{Ma} \mathrm{CO}$ & Irrectior & for comm & In $\mathrm{Pb} \mathrm{me}$ & A using th & neasured & $7^{358} \mathrm{~Pb}$ ar & $\mathrm{d}^{20 /} \mathrm{Pb} f^{200} \mathrm{P}$ & atios & & & & & & & & & \\
\hline & & & following & Tera an & Wasserburg & (1972) & is oullined & in Willia & is (1998). & & & & & & & & & & & & & \\
\hline & & 6. For: & $\%$ Disc, 0 & $\%$ deno & es a concorda & int anal & & & & & & & & & & & & & & & & \\
\hline
\end{tabular}

